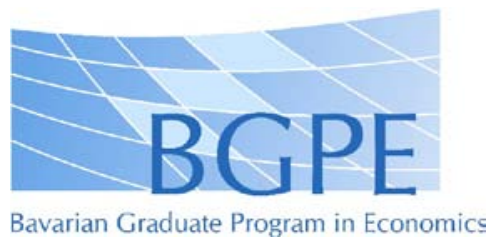

BGPE Discussion Paper

No. 114

\title{
Wage Mobility in East and West Germany
}

\author{
Regina T. Riphahn \\ Daniel D. Schnitzlein
}

December 2011

ISSN 1863-5733

Editor: Prof. Regina T. Riphahn, Ph.D.

Friedrich-Alexander-University Erlangen-Nuremberg

(c) Regina T. Riphahn, Daniel D. Schnitzlein 


\title{
WAGE MOBILITY IN EAST AND WEST GERMANY *
}

\author{
REGINA T. RIPHAHN
}

DANIEL D. SCHNITZLEIN

December 20, 2011

word count (main text): 8.198

This article studies the long run patterns and explanations of wage mobility as a characteristic of regional labor markets. Using German administrative data we describe wage mobility since 1975 in West and since 1992 in East Germany. Wage mobility declined substantially in East Germany in the 1990s and moderately in East and West Germany since the late 1990s. Therefore, wage mobility does not balance recent increases in cross-sectional wage inequality. We apply RIF (recentered influence function) regression based decompositions to measure the role of potential explanatory factors behind these mobility changes. Increasing job stability is an important factor associated with the East German mobility decline.

Keywords: wage mobility, earnings mobility, income mobility, Germany, East Germany, inequality, transition matrix, Shorrocks index, administrative data

JEL Code: J30, J31, J60, D63

Correspondence to:

Regina T. Riphahn

Univ. Erlangen-Nuremberg

Lange Gasse 20

90403 Nuremberg

Germany

Phone: +49 - (0)911 - 5302826

Fax: $\quad+49-(0) 911-5302178$

Email: Regina.Riphahn@wiso.uni-erlangen.de

*We thank Richard V. Burkhauser, Stephen Jenkins, the econometrics group and the social policy group of the German Economic Association, seminar participants at RWI-Essen, Mannheim, Zurich, and Mainz, workshop participants at the DFG-SPP program meeting in Nuremberg, the IAB-IWH Workshop Halle, the IAB-FDZ user conference, and the Scottish Economic Association for helpful comments. Schnitzlein acknowledges financial support by the Institute for Employment Research (IAB). 


\section{INTRODUCTION}

Even though high income mobility can, both, increase or reduce individual welfare, the economic literature tends to stress its beneficial aspects. High income mobility promises the disadvantaged of today a better position in the future and balances the distribution of lifetime incomes. Friedman (1962) introduced the notion that income mobility can equalize long-term personal incomes and Shorrocks' (1978) index measures to what extent income mobility reduces income inequality. A broad and often methodological literature studies wage and earnings mobility, its development over time and in international comparison. ${ }^{1}$

Motivated by the recent rise of wage inequality in Germany (e.g., Dustmann et al. 2009), by the availability of new, long running administrative data, and by the event of German unification in 1990 this article studies wage mobility in Germany. We describe wage inequality and mobility over the last 35 years in West Germany and the trends since unification in former communist East Germany. In addition, we test hypotheses regarding the potential mechanisms behind aggregate mobility shifts using linked employee-employer data. Our novel approach to the study of wage mobility generates new insights on structural shifts in the East German transition economy and in the German labor market over time.

So far, the international evidence on the development of wage mobility over time does not yield unambiguous conclusions or general trends. Kopczuk et al. (2010) investigate U.S. earnings inequality and mobility between 1937 and 2004 and find that short-run mobility was rather stable since the 1950s. In contrast, longer-run mobility has been increasing for females and slightly declining for males. ${ }^{2}$ Dickens (2000) evaluates British evidence on wage mobility

\footnotetext{
$1 \quad$ For recent contributions on the U.S. see Kopczuk et al. (2010), Shin and Solon (2011), Buchinsky and Hunt (1999), for studies on the U.K. see Jenkins (2011), Dickens (2000), or Jarvis and Jenkins (1998), a recent contribution on France is Buchinsky et al. (2003), two studies on Austria are Hofer and Weber (2002) and Raferzeder and Winter-Ebmer (2007). For comparative studies see Aaberge et al. (2002), Chen (2009), van Kerm (2004, 2006), Jenkins and van Kerm (2006), Maasoumi and Trede (2001), Gottschalk and Spolaore (2002), Ayala and Sastre (2008), OECD (1997) and for methodological contributions Fields and Ok (1999a, 1999b, 1996) or Gregg and Vittori (2008) among others.

2 Buchinsky and Hunt (1999) study wage mobility for the aging cohorts of National Longitudinal Survey of Youth and find falling mobility over the time period 1979-1991. Recently, Dahl et al. (2011) show that based on administrative data U.S. year-to-year earnings volatility has been about constant between 1985 and 2005.
} 
from 1975 to 1994 and concludes that mobility has been declining since the 1970s. Jenkins (2011) considers the period 1991 to 2006 based on the British Household Panel Survey and finds hardly any mobility change over time. Buchinsky et al. (2003) find falling mobility in French earnings between 1967 and 1999.

Most prior contributions on German wage mobility used the German Socio-Economic Panel (SOEP), which covers West Germany since 1984 and East Germany since 1990. This literature is dominated by comparisons of West German and U.S. wage mobility. ${ }^{3}$ The results vary, as different survey years, income measures, and mobility indicators are applied. Some authors find that wage mobility is higher in the U.S. (Burkhauser et al. 1997, Chen 2009) and others find the opposite even for the same period of observation. ${ }^{4}$ Only few studies evaluate mobility developments over time. In their comparison of East and West German income mobility early after unification Hauser and Fabig (1999) find that mobility was initially much higher in East Germany but declined already by 1995. Gernandt (2009) and Bayaz-Ozturk et al. (2011) apply SOEP data (1984-2007) for West Germany and find declining mobility, while Bartels and Bönke (2010) find rising earnings volatility among West German males.

Most studies in the international literature on wage and income mobility focus on the measurement and description of mobility without explicit attention to its determinants. Among the contributions addressing mobility developments, three approaches dominate. The first approach was initiated by Lillard and Willis (1978), Lillard and Weiss (1979), MaCurdy (1982), and Abowd and Card (1989). These studies only indirectly analyze aggregate mobility developments as they follow individual wages and earnings over time and focus on the covariance structure of earnings. They determine the time series representation of individual wages which fits the data best. ${ }^{5}$ This literature differs from our approach in that it studies the

3 See, e.g., Burkhauser et al. (1997), Burkhauser and Poupore (1997), Maasoumi and Trede (2001), Gottschalk and Spolaore (2002), van Kerm (2004), Jenkins and van Kerm (2006), and Chen (2009).

4 See, e.g., Burkhauser and Poupore (1997), Maasoumi and Trede (2001), Gottschalk and Spolaore (2002). Jenkins and van Kerm (2006) consider this difference to be a function of the type of mobility measure. For more recent contributions see e.g., Baker (1997) and Meghir and Pistaferri (2004, 2010). 
stochastic nature of the individual earnings process over time rather than considering mobility as an aggregate labor market characteristic.

The second approach in the study of mobility consists of decompositions of mobility indicators and comprises numerous procedures: (a) some authors consider different mobility patterns for different types of household incomes (e.g., Chen 2009), (b) some split the sample in different subsamples (e.g., Maasoumi and Trede 2001, van Kerm 2004, Ayala and Sastre 2008, Chen 2009), or (c) differentiate between and within group mobility (Buchinsky and Hunt 1999); (d) some studies consider different contributions to overall mobility for different quantiles of the initial distribution (Gregg and Vittori 2008, van Kerm 2003, 2006), and, finally, (e) based on Fields and Ok (1999b) some authors decompose mobility into mobility due to overall economic growth and mobility due to the transfer of income within a given distribution (e.g., Chen 2009, van Kerm 2004, Ayala and Sastre 2008).

Finally, a third approach studies individual-level determinants of wage dynamics: Hunt (2001) investigates the determinants of year-to-year changes in East German wages immediately after unification. Finnie and Gray (2002), Raferzeder and Winter-Ebmer (2007), Gernandt (2009), and Auten and Gee (2009) investigate correlation patterns of changes in individual income positions. Generally, these authors find that wage mobility is concentrated among the young and that mobility varies with the initial position in the income distribution.

This study contributes to the literature in several ways. First, we study German wage mobility based on a new administrative data set. Our data provide large samples, go back further in time than prior contributions, i.e., to 1975, and also cover very recent developments, i.e., through 2008. Compared to survey data, our administrative data promise higher precision, less measurement error, and less attrition (see Gottschalk and Huynh 2010). Second, the data allow us to compare the developments in the transition economy of East Germany and the established market economy of West Germany in the period after unification. This specific perspective is missing in the extant literature. Third, we apply a broad set of mobility 
indicators to establish reliable stylized facts. Finally, we go beyond the mere description of wage mobility over time and between regional subsamples and test hypotheses regarding explanatory factors associated with changes in wage mobility. We apply aggregate and detailed decompositions based on recentered influence function (RIF) regressions as introduced by Firpo, Fortin, and Lemieux (2009) and discussed in Fortin, Lemieux, and Firpo (2011) to quantify the contribution of potential determinants of aggregate mobility.

Our main results are as follows: first, we observe substantial declines in East German wage mobility in the 1990s and moderate mobility reductions in both East and West Germany since the late 1990s. Since about 1997, wage mobility in East Germany is below West German levels. Second, we confirm the extant evidence on rising wage inequality in Germany. Both stylized facts suggest that mobility is less and less effective as an "equalizer" of inequality as suggested by Friedman (1962). Third, the results yield that a substantial part of the mobility decline in East Germany is associated with changes in observable worker characteristics, particularly those describing job stability and employment characteristics. However, also structural shifts and unexplained factors contributed to the decline in wage mobility in both parts of Germany.

The paper proceeds as follows: in section two we describe our data, sample, and measurement issues. Section three describes the developments of inequality and mobility in West and East Germany. In section four we derive our hypotheses on the potential determinants of mobility from the literature and outline our empirical approach to test them. We present and discuss the empirical results in section five before we conclude in section six.

\section{DATA AND MEASUREMENT Issues}

Our analysis uses the newly available SIAB (Sample of Integrated Labour Market Biographies, 1975-2008) data, a two percent random sample of administrative records and successor of the widely used IABS data (for additional information on the data see the 
electronic appendix). The data contain the employment history of 1.6 million individuals and inform about benefit receipt, job-search, and individual characteristics that can be matched with establishment characteristics. The data describe all individuals covered by the statutory retirement insurance, i.e., about 80 percent of the German labor force, as well as all individuals registered with the federal employment agency. ${ }^{6}$

The SIAB data have two weaknesses. First, they provide only a limited number of covariates, e.g., we only know about workers' full-time vs. part-time employment status rather than the actual number of hours worked. Second, the information on daily wages is censored: since retirement insurance contributions are paid as a fixed earnings share only up to an upper threshold, earnings values beyond the threshold are not registered in the data. This threshold value is fixed nominally every year, separately for East and West Germany. We apply 'consistent top-coding' to avoid time inconsistencies in the share of censored observations (see Burkhauser et al. 2009) and censor the top 15 and 10 percent of each annual wage distribution for West and East Germany, respectively.

Our sample covers all full-time employed individuals in East and West Germany, between 25 and 60 years of age. We consider every individual who is employed full-time at some point in the calendar year. East and West German subsamples are distinguished based on the individuals' place of work. In the analysis of wage mobility between periods $t$ and $t+k$ we use observations who were full-time employed in the base $(t)$ and the final $(t+k)$ reporting year, who worked in the same region of the country at both points in time, and who met the age restrictions in both periods. Table A.1 in the Appendix provides the overall number of observations used in the mobility analysis for the two regional samples by year. Our key variable of interest describes real daily wages in 2008 Euro. Similar to Dustmann et al. (2009), we disregard employment relationships with daily wages below 12 Euro.

\footnotetext{
6 Excluded are civil servants, self employed workers, and those in military service. Individuals are registered with the federal employment agency, e.g., if they are unemployed or participate in training measures.
} 


\section{INEQUALITy AND MobILITy PATTERnS IN EAST AND WeSt GERMANY}

\section{III.A. Inequality Patterns}

In this section we briefly replicate the evidence on wage inequality in Germany as presented, e.g., by Dustmann et al. (2009). Based on the SIAB data, we extend their observation window to include both more recent years and the East German subsample.

Figure I presents the development of real wages at the 20th, 50th, and 80th percentile of the full wage distribution, i.e., including censored observations, as well as the real censoring threshold over time. The 80th percentile of the distribution always remains below the censoring threshold. The evidence on West German inequality confirms prior findings (e.g., Dustmann et al. 2009, Gernandt 2009, Fuchs-Schündeln et al. 2010, Bönke et al. 2011): inequality rises in the upper part of the distribution since the early 1980s and in the lower part of the distribution since the early 1990s, recently with falling real wages at the 20th percentile. In East Germany, inequality in the top half of the distribution increased over time, while the 20th and 50th percentiles moved almost in tandem. Again, real wages at the median and below have been falling. Appendix Figure A.1 presents the relative development of real wages since 1975 in West and since 1992 in East and West Germany. We find higher wage growth for the upper than for the lower percentiles of the wage distributions, with higher growth rates in East than in West Germany. Inequality rose both in the upper and the lower half of the distributions.

Finally, we depict aggregate inequality developments using three distributional measures: Gini coefficients and the mean log deviation of annual real wages in Figure II.A and the spread between the 80th and 20th percentile of the annual wage distribution in Figure II.B, separately for the two regional subsamples. ${ }^{7}$ In West Germany, wage inequality has been

\footnotetext{
$7 \quad$ We also studied the Gini coefficients for the full earnings distribution including censored values. The developments are very similar to those depicted for the uncensored part of the distribution.
} 
rising steadily, in particular since the late 1990s. In East Germany, wage inequality has been rising continuously since 1992. - Increasing cross-sectional wage inequality does not have to enhance permanent and lifetime inequality if it is balanced by increasing intertemporal wage mobility. Next, we study the development of wage mobility over time.

\section{III.B. Mobility Patterns}

The literature uses a number of different indicators of wage mobility. To ensure that our findings are reliable and independent of any particular measure, we apply different indicators. We first study indicators that are based on individual rank positions in the wage distribution. In particular, we look at (a) the probability of shifting to a different quintile of the wage distribution, (b) the probability of jumping by more than 10 rank positions, (c) the distribution of changes in rank positions, and (d) rank correlations over different interval durations in East and West Germany. As our second set of indicators we consider the development of mean absolute and relative wage changes. Finally, we present evidence based on Shorrocks' index, which describes the extent to which short term wage mobility can reduce long term inequality.

Figure III summarizes annual transition matrices, which show the probability of staying in a given quintile between periods $t$ and $t+4$ as well as the probability of moving by one, two, three, or four quintiles. For the West German sample we present the developments since 1975, for the East German sample those since 1992. Since the last year of our data is 2008, the last depicted transition refers to the starting year 2004 and represents the mobility between 2004 and 2008. Among West Germans (see top panel) mobility appears to be rather stable. Only recently, the share of immobile workers, who remain in a given wage quintile increased (labeled "Stayer") and the corresponding probability of position shifts by one or two quintiles dropped slightly. The probability of larger position shifts remained below ten percent. The shifts in East German mobility are more pronounced. Here the probability of 
staying in a given quintile, increased since 1992 from around 50 to 70 percent (see bottom panel) and thus assimilated to West German levels. Overall, we observe a trend to lower mobility, particularly in East Germany. This matches the evidence provided by Gernandt (2009) using SOEP data and the picture drawn for U.S. males by Kopczuk et al. (2010).

As a second and somewhat more detailed indicator based on rank positions, we study the development of the probability of changing the individual rank position by more than 10 percentage points within a window of four years. Figure IV presents the development for the two regional subsamples. A high probability of a ten percentage point shift reflects high mobility. The mobility level in West Germany slightly declined between 1975 and 1985, it increased through 1989, and subsequently declined substantially from about 40 to 30 percent. The East German development is striking: mobility declined from about 55 initially to about 25 percent, i.e., to levels clearly below West German values.

One shortcoming of quintile or 10 percentage point transitions is that they do not describe developments within the considered ranges. ${ }^{8}$ Figure $\mathrm{V}$ addresses this problem and presents the distribution of changes in relative rank positions separately for three periods in West and for two periods in East Germany. The dispersion in rank adjustments over time is roughly constant in West Germany (see top row). In East Germany (see bottom row) the variance of the rank change distribution visibly declines between the first and the second observation period (1992-1996 vs. 2004-2008).

Figure VI presents the development of individuals' rank correlation coefficients over time, for East and West Germany, and for time intervals of different lengths. The shorter the observation window, the higher are the measured correlations. Overall, rank correlation coefficients and thus immobility increase over time. In East Germany, immobility increases strongly and eventually surpasses West German levels.

8 In addition, these mobility indicators cannot differentiate between more or less dispersed distributions. 
In our second group of mobility measures we calculate the development of absolute and relative changes in real wages over time. Rising wage changes would be suggestive of increasing mobility. Appendix Figure A. 2 shows mean absolute individual real wage changes across intervals of different lengths for the regional subsamples over time. While the values fluctuate, the overall patterns are clear, particularly when considering wage developments over longer periods: mean absolute wage changes trend downwards both in East Germany since the first measurements and in West Germany since the mid 1980s. Appendix Figure A.3 describes mean relative wage changes over time. Again, wage changes decline, which confirms the decline in wage mobility that we found using other indicators.

The correlation patterns over alternative time horizons already indicate that mobility developments can vary in the short and the long run. The Shorrocks index describes the extent to which wage mobility balances short-run inequality (Shorrocks 1978). If period-specific inequality is measured by an indicator $G(\mathrm{z})$, we can compare the average of $\mathrm{T}$ period-specific inequality measures with inequality averaged over T periods, i.e., $G(\bar{z})$. If the latter is smaller than the former, intertemporal mobility serves to reduce short-run inequality:

$$
\mathrm{G}(\overline{\mathrm{z}}) \leq \sum_{\mathrm{t}=1}^{\mathrm{T}} \mathrm{G}\left(\mathrm{z}_{\mathrm{t}}\right) / \mathrm{T}
$$

The Shorrocks index is defined as M with

$$
M=1-\frac{G(\bar{z})}{\sum_{t=1}^{T} G\left(z_{t}\right) / T}
$$

If mobility reduces income inequality, the inequality of averaged incomes $(\bar{z})$ is below the average of period-specific inequality measures. The larger the difference between these two indicators, the larger mobility and the closer $\mathrm{M}$ is to one. If there is no mobility, the inequality 
of the average and the average of the inequality measures are identical and $\mathrm{M}$ is close to zero. ${ }^{9}$ Figure VII presents the development of the Shorrocks index when we apply two alternative inequality indicators G, mean log deviation and the Gini coefficient to East and West German samples. The developments over time are similar to prior measures. Overall, mobility in West Germany is lower in the early 2000s than in the 1970s, even though the process was not one of a linear decline. In East Germany, mobility has been declining without interruption since unification. East German mobility soon fell below West German levels.

So far, we used censored administrative data which yield biased results if important developments occur in the censored part of the distribution (see Burkhauser et al. 2011). In order to find out whether this is likely to affect our conclusions we repeat our analyses using uncensored survey data taken from the German Socio-Economic Panel (SOEP). In the electronic appendix we present the developments of the Shorrocks index for East and West Germany using both uncensored and censored data. For the censored data we use only that part of the wage distribution that is available in our administrative data after consistent topcoding. Generally, we observe higher mobility for the censored than for the complete distributions. However, the overall development of the mobility indicator does not differ between the censored and the uncensored samples: in each of our four panels where we use two alternative inequality measures for East and West Germany the developments are parallel. Therefore, we are confident that the results based on the much richer but censored administrative data are not systematically biased by censoring.

Overall, the evidence supports two stylized facts: (i) wage mobility declined over time and (ii) it declined faster in East than West Germany. Next, we study potential mechanisms behind the robust decline in wage mobility.

\footnotetext{
9 The literature applies a variety of inequality measures to calculate Shorrocks' index (e.g., the Gini coefficient, mean log deviation, Theil I1, or Theil I2), which vary in their sensitivity to changes in different parts of the income distribution (e.g., Hofer and Weber 2002). We present results using the Gini coefficient, which is particularly sensitive to changes in the middle of the distribution and the mean log deviation which is particularly sensitive to changes in the lower part of the distribution.
} 


\section{EXPlaining THE MobILITy DECLINE: HyPotheSES AND EMPIRICAL APPROACH}

\section{IV.A. Hypotheses}

The literature offers a range of hypotheses that may explain changes in aggregate wage mobility. These hypotheses fall in four groups: a first group of factors considers individual characteristics (Z), which are connected to labor supply; closer to labor demand, a second group of potential mobility determinants focuses on job stability (J) and a third group on employment characteristics (E). A last group considers regional and aggregate developments (R) as potential determinants of wage mobility. Next, we discuss each of the four groups of hypotheses which we later test empirically.

Wage mobility is affected by individual characteristics including changes over the lifecycle (Drewianka 2010, Raferzeder and Winter-Ebmer 2007, Gernandt 2009, Aaberge et al. 2002, Sabelhaus and Song 2010, Kohn and Antonczyk 2011, Bönke et al. 2011). Mobility dropped the most for the East German labor force and, clearly, the composition of the East German labor force with respect to age, sex, and education has changed substantially since unification: East Germany experienced demographic aging and fertility declines (Lechner 2001), selective out-migration (Hunt 2006, Fuchs-Schündeln and Schündeln 2009), modifications of the education system (Riphahn and Trübswetter 2011), and shifts in female labor force participation (Hanel and Riphahn 2011). In order to gauge the joint effects of changes in work force characteristics we consider as individual characteristics (Z) age, sex, education, citizenship, an indicator for whether an individual will leave East German for the West in the future, and the rank position in the income distribution in the base period starting from which mobility is measured.

Wage mobility is typically associated with job changes. Therefore, aggregate changes in job stability are likely to be connected to shifts in wage mobility (Stevens 2001, Farber 2007 and 2008, Shin and Solon 2011, Gottschalk and Moffitt 1994 and 2009). In the U.S., job 
stability declined recently suggesting an increase in wage mobility. In East Germany job stability increased since unification, which should reduce wage mobility. To quantify such mechanisms, we consider three indicators of job stability (J): individual employer change, unemployment experience between $t$ and $t+4$, and current tenure.

A third group of factors relevant to wage mobility relates to employer and employment characteristics. In this group we distinguish four different mechanisms. First, the recent decline in unionization and wage compression may contribute to the rise in wage inequality (e.g., Dustmann et al. 2009, Antonczyk et al. 2010, Kohn and Antonczyk 2011) and may affect wage mobility (Gottschalk and Moffitt 1994). Particularly in East Germany, employers left collective bargaining arrangements as a result of overly generous wage agreements (Stephen and Schroeder 2007). Second, Gottschalk and Moffitt (1994) argue that employment shifts between industries affect aggregate wage mobility if workers move from more stable (e.g., manufacturing) to more instable (e.g., services) industries. This is particularly relevant for the East German industrial structure which adjusted after unification with shifting industry and employer size composition (see Kohn and Antonczyk 2011). As a third mechanism, Comin et al. (2009) and Gottschalk and Moffitt (2009) show the connection between the volatility of firm performance and wage mobility. Fourth and finally, given the relevance of occupation-specific human capital (Schmillen and Möller 2010, Firpo et al. 2011), of skill biased technical change, and increasing specialization it may have become more difficult to transfer human capital between employments over time (Gottschalk and Moffitt 2009). This again may affect wage mobility. To control for the impact of these mechanisms on wage mobility we consider (E) employer size, and its change between $t$ and $t+4$ as indicators of employer stability and control for employees' industry and occupation as of period $\mathrm{t}$ and for their changes over time.

Our fourth and final set of factors considers regional developments that might affect wage mobility such as the business cycle, unemployment rates, GDP growth, and regional 
employment structures, e.g., the share of the self-employed (Gottschalk and Moffitt 1994 and 2009, and Anger 2011). As summary measures for these macroeconomic mechanisms we consider state-level fixed effects.

In order to determine which of the four factor groups contributes most strongly to the decline in German wage mobility, we pursue a decomposition approach (Fortin et al. 2011). The decomposition framework suggests that the observed mobility decline must be connected either to composition effects, i.e., to shifts in the observable explanatory factors behind wage changes, or to structure effects, i.e., to shifts in unobservables or in correlation patterns as reflected in regression coefficients. We first evaluate the magnitude of overall composition and structure effects and then study the relevance of the four factor groups separately.

\section{IV.B. Empirical Approach}

To quantify the contribution of the four factor groups to the change in wage mobility over time we apply the recentered influence function (RIF) method as introduced by Firpo et al. (FFL 2009) and discussed in Firpo et al. (FFL 2007) and Fortin et al. (FLF 2011). Similar to the Oaxaca Blinder decomposition which focuses on differences in the means of distributions, the RIF method permits decompositions of differences in functionals of distributions such as the variance. The aggregate decomposition separates the effect of changes in characteristics and coefficients, while the detailed decomposition assigns (groups of) covariates their specific contribution to the difference in the distributional measure.

As our indicator of wage mobility we use the variance of the distribution of individual changes in rank positions in annual wage distributions between periods $t$ and $t+4$, separately for East and West Germany (see Figure V). The measure reflects our interpretation of wage mobility as a characteristic of regional labor markets. Let $y_{i}$ represent the change in the relative rank position of individual $i$ between period $t$ and $t+4 \cdot y_{i}$ takes on values in the interval $[-99,99]$. In a balanced panel of individual wage observations the mean of $y$ is zero 
and independent of wage mobility. Wage mobility is reflected in the variance of $y$ : labor markets with high wage mobility are characterized by a high dispersion of rank changes while labor markets with low wage mobility feature mostly small changes in rank positions and thus a small variance of $y$.

We are interested in decomposing the observed change in mobility. We compare the variance of an early and a late period to measure the impact of changes in the distribution of covariates at the individual and aggregate level on the change in the variance of $y$. The influence function of the variance, $\operatorname{IF}\left(y_{i} ; \sigma^{2}\right)$, describes the influence of an individual observation $y_{i}$ on the aggregate variance, $\sigma^{2}$ :

$$
\operatorname{IF}\left(y_{i} ; \sigma^{2}\right)=\left(y_{i}-\int z \cdot d F_{y}(z)\right)^{2}-\sigma^{2}
$$

The recentered influence function (RIF) adds this influence function back to the observed variance (see equation 4), which after substituting the expected value of the influence function yields the original variance (see equation 5):

$$
\begin{aligned}
& \operatorname{RIF}\left(y_{i} ; \sigma^{2}\right)=\operatorname{IF}\left(y_{i} ; \sigma^{2}\right)+\sigma^{2} \\
& \operatorname{RIF}\left(y_{i} ; \sigma^{2}\right)=\left(y_{i}-\int z \cdot d F_{y}(z)\right)^{2}=\left(y_{i}-\mu\right)^{2} .
\end{aligned}
$$

FFL (2007) show that the conditional expectation of $\operatorname{RIF}\left(y_{i} ; \sigma^{2}\right)$ can be modeled as a linear function of explanatory variables $X$ :

$$
\mathrm{E}\left(\operatorname{RIF}\left(\mathrm{y}_{\mathrm{i}} ; \sigma^{2}\right) \mid \mathrm{X}\right)=\mathrm{X}_{\mathrm{i}} \cdot \gamma
$$

The RIF regression coefficients $(\gamma)$ provide partial effects of changes in the distribution of the covariates $X$ on the variance of the conditional distribution of $y$. In this framework we can separate the contribution of covariate $(X)$ and structure effects to the 
explanation of overall changes in wage mobility over time. ${ }^{10}$ The overall change in wage mobility between a late $(t=0)$ and an early $(t=1)$ period is defined as

$$
\Delta_{\mathrm{O}}^{\sigma^{2}}=\sigma_{0}^{2}-\sigma_{1}^{2}
$$

and can be decomposed into two parts

$$
\Delta_{\mathrm{O}}^{\sigma^{2}}=\Delta_{\mathrm{S}}^{\sigma^{2}}+\Delta_{\mathrm{X}}^{\sigma^{2}}
$$

where $\Delta_{\mathrm{x}}^{\sigma^{2}}$ represents the composition and $\Delta_{\mathrm{S}}^{\sigma^{2}}$ the structure effect. FFL (2007) show that this decomposition can be obtained as the Oaxaca Blinder decomposition of equation (6).

However, the authors recommend a two step procedure: the first step consists of reweighting the data following the well known DiNardo et al. (1996) procedure. The objective of this reweighting procedure is to account for potential non-linearities in the true conditional expectation of equation (6). Without reweighting, the decomposition yields consistent results only if the true conditional expectation of equation (6) is in fact linear, which imposes a strong assumption on the data. The reweighting procedure generates counterfactual observations $(t=2)$ that result if individuals of the late period $(t=0)$ had the same distribution of observable characteristics as individuals observed in the early period $(t=1)$. The reweighting procedure is based on estimating a probit model on the probability of being observed in the early period. ${ }^{11}$

In the second step the decomposition analysis is then performed on the reweighted data. The composition and structure effects are calculated as follows:

$$
\begin{aligned}
\Delta_{\mathrm{X}}^{\sigma^{2}} & =\left(\overline{\mathrm{X}}_{2}-\overline{\mathrm{X}}_{0}\right) \hat{\gamma}_{0}+\overline{\mathrm{X}}_{2}\left(\hat{\gamma}_{2}-\hat{\gamma}_{0}\right) \\
& =\left(\overline{\mathrm{X}}_{2}-\overline{\mathrm{X}}_{0}\right) \hat{\gamma}_{0}+\hat{\mathrm{R}}_{\mathrm{x}}^{\sigma^{2}}
\end{aligned}
$$

and

The literature frequently uses the terminology of explained vs. unexplained effects. We follow FLF (2011) and label explained effects composition effects and unexplained effects structure effects.

Our probit specification considers the explanatory variables of the decomposition analysis and their interactions. The results of the reweighting are presented in the electronic appendix, including the difference of the mean characteristics in the reweighted and original period. These differences are small or equal to zero in almost all cases. 


$$
\begin{aligned}
\Delta_{\mathrm{S}}^{\sigma^{2}} & =\overline{\mathrm{X}}_{1}\left(\hat{\gamma}_{1}-\hat{\gamma}_{2}\right)+\left(\overline{\mathrm{X}}_{1}-\overline{\mathrm{X}}_{2}\right) \hat{\gamma}_{2} \\
& =\overline{\mathrm{X}}_{1}\left(\hat{\gamma}_{1}-\hat{\gamma}_{2}\right)+\hat{\mathrm{R}}_{\mathrm{S}}^{\sigma^{2}}
\end{aligned}
$$

$\hat{\mathrm{R}}_{\mathrm{x}}^{\sigma^{2}}$ represents the approximation error, which reflects the imprecision of the approximation of $\Delta_{\mathrm{x}}^{\sigma^{2}}$ through RIF regressions. The approximation error is large if the linearity of the RIF regression is inappropriate and disappears if the conditional expectation of the variance is indeed linear in $X$ (see FFL 2007). $\hat{\mathrm{R}}_{\mathrm{s}}^{\sigma^{2}}$ represents the reweighting error that disappears if the reweighting matrix is consistently estimated and plim $\overline{\mathrm{X}}_{2}=$ plim $\overline{\mathrm{X}}_{1}$.

The results identify $\Delta_{\mathrm{x}}^{\sigma^{2}}$ and $\Delta_{\mathrm{S}}^{\sigma^{2}}$ under two assumptions. (i) The ignorability assumption requires that conditional on $X$ the unobservable determinants of the dependent variable in equation (6) are independent of the assignment to treatment group t, i.e., to the early vs. late period in our mobility comparison. As our specification considers a rich set of indicators that reflect time varying processes (e.g., age, unemployment experience, or tenure) it seems unlikely that unobservables could be correlated with the assignment to the treatment group. (ii) The assumption of overlapping support requires that no value of covariates $X$ is exclusively observed among members of group 0 or group 1 . In our case this is innocuous.

To test our hypotheses and to determine the contribution of different groups of covariates to the decline in wage mobility over time we use linear regressions of the individual contribution to aggregate wage mobility considering the four factor groups $(Z, J, E$, and $\mathrm{R}$ ) defined above and $\varepsilon$ as a random error term:

$$
\operatorname{RIF}\left(\mathrm{y} ; \sigma^{2}\right)=\gamma_{0}+\mathrm{Z} \gamma_{1}+\mathrm{J} \gamma_{2}+\mathrm{E} \gamma_{3}+\mathrm{R} \gamma_{4}+\varepsilon
$$

Based on this model we can calculate composition (12) and structure (13) effects for each covariate group $k$ :

$$
\sum_{k=1}^{K}\left(E\left[X^{k} \mid t=1\right]-E\left[X^{k} \mid t=0\right]\right)^{\prime} \cdot \hat{\gamma}_{0, k}^{\sigma^{2}}
$$




$$
\sum_{\mathrm{k}=1}^{\mathrm{K}} \mathrm{E}\left[\mathrm{X}^{\mathrm{k}}, \mathrm{t}=1\right]^{\prime} \cdot\left(\hat{\gamma}_{1, \mathrm{k}}^{\sigma^{2}}-\hat{\gamma}_{2, \mathrm{k}}^{\sigma^{2}}\right)
$$

Under the stated assumptions this procedure can be applied to evaluate the contribution of the four factor groups to the observed change in wage mobility. We follow FFL 2007 and estimate the standard errors of all indicators by bootstrap procedures.

There are several advantages connected to the application of the RIF procedure: first, it allows us to decompose the patterns behind changes in variances; second, in contrast to other decomposition procedures it permits both aggregate and detailed decompositions; third, the results of the detailed decomposition for each group of covariates are not path dependent. However, the RIF procedure also suffers the disadvantages of the Oaxaca Blinder decomposition: the measured contribution of covariates to the structure effect depends on the reference group and results generally depend on which of the two comparison groups $t=0,1$ is the reference. In response to the first disadvantage we do not present detailed structure effects. In response to the second point we perform a robustness check of our results.

\section{IV.C. Descriptive Evidence}

The dependent variable of the RIF regression (see equations 6 or 11) describes the individual contribution to the variance of the wage change distribution. The means of the dependent variable are depicted by region and calendar year in Figure VIII: for any year $t$ it shows the variance of the distribution of individual rank changes between periods $t$ and $t+4$. The patterns in Figure VIII strongly resemble those in Figures IV and VII. In the early 1990s wage mobility was substantially higher in East than in West Germany. Since then wage mobility continuously declined in East Germany. In West Germany, mobility has been declining since 1997. Nevertheless, since 1996 East German wage mobility is below West German levels, which confirms the results of section III above. 
To study its heterogeneity we depict wage mobility by age and quintile position in base period t. Wage mobility declines over the life-cycle in both regions and all years (see Figure A.4). Also, wage mobility clearly dropped in East Germany over time. Wage mobility also varies by starting position (see Figure A.5). Generally, we observe the least mobility in the highest (non-censored) wage quintile and mobility tends to be highest for members of the lowest quintile.

In our empirical analysis, we focus on East and West German developments since unification. We evaluate the impact of the four factor groups based on the indicators discussed in section IV.A. These indicators are described in the electronic appendix.

\section{RESULTS AND DISCUSSION}

\section{V.A. Empirical Results}

The empirical analysis evaluates the contribution of the four factor groups to the decline in wage mobility. First, we regress the individual contribution to the aggregate variance on the four factor groups (see equation 11). The estimates are available in an electronic appendix and are omitted here to save space. The coefficient estimates for the four factor groups are all jointly highly statistically significant.

We present the results of the decomposition analysis in Table I, where we compare wage mobility observed in the early years after unification (base year $t=1993)^{12}$ to that observed most recently (base year $t=2004$ ). Panel A of Table I describes that the observed variance of the rank change distribution dropped by half in East and by 15 percent in West Germany over the observed period. Panel B of Table I presents the results of the aggregate decomposition, where we distinguish the contribution of composition $\left(\Delta_{\mathrm{x}}^{\sigma^{2}}\right)$ and structure effects $\left(\Delta_{\mathrm{s}}^{\sigma^{2}}\right)$ to the overall change in wage mobility over time. In East and West Germany

\footnotetext{
12 In contrast to our descriptive results on East Germany which start in 1992, we use 1993 as the base year for our multivariate analyses to avoid measurement problems. East German data collection commenced only in 1991 and some commentators consider the early evidence as unreliable.
} 
most of the change in wage mobility is associated with structural shifts, i.e., with changes in correlation patterns and the relevance of unobservables. However, in East Germany a statistically significant share of about 40 percent of the total decline in wage mobility is associated with composition effects, i.e., with changes in observable characteristics. Panel C of Table I presents the contribution of changes in observable characteristics by factor group. In both regions changes in job stability $(J)$ and employment characteristics $(E)$ contributed the most to the composition effect. While in East Germany changes in all factor groups contribute to a decline in wage mobility, the shifts in job stability $(J)$ and employment $(E)$ characteristics in West Germany would have increased wage mobility. Surprisingly, the contribution of individual level characteristics $(Z)$ in East Germany is relatively small: if the mobility decline were driven by migration and ensuing changes in population characteristics this should have generated a more substantial contribution of factor group $Z$ to the total composition effect.

The bottom rows of Table I describe the magnitude of the approximation and the reweighting errors. For East Germany the approximation error to the true functional form of the composition effect is negligible, for West Germany it takes on a value of -5 . The statistically significant reweighting error for East Germany indicates that there remains a difference between the characteristics of the compared groups even after reweighting.

Overall, the substantial decline in East German wage mobility is connected to both composition and structure effects whereas the small change in West Germany is accounted for by structure effects. In principle, it is possible to also decompose structure effects and to evaluate the contribution of each factor group. However, because the results vary substantially depending on the chosen reference group, we prefer not to present a-necessarily arbitrarydecomposition of the structure effect. ${ }^{13}$

\footnotetext{
13 We present the results of the aggregate decomposition with swapped period assignments ( 1 vs. 0$)$ in the electronic appendix. The results are robust to the direction of the decomposition.
} 
Instead, we refine our decomposition analysis and break the observation window in two periods. Figure VIII shows that the mobility decline differs strongly for the two regions in the 1990s and develops in parallel in more recent years: in Table II separately present the results of a decomposition comparing first the base years 1993 and 1998 and then the base years 1998 and 2004. Panel A confirms that the East German mobility decline slowed down substantially after the first period, whereas the West German mobility decline only started after 1998 (see row labeled change). The mobility decline in the second period was of about equal size in East and West Germany.

Panel B again separates the contributions of structure and composition effects. Both contribute significantly to all observed changes. In East Germany, the patterns differ for the first and the second period. Whereas in the early period about one quarter of the overall mobility change is associated with shifts in characteristics that share increases to about more than 60 percent in the second period. In West Germany, the variance changed little in the first period and the decline in the second period is connected to both, composition and structure changes. Across both regions and periods the detailed decomposition of the characteristics effect in Panel $\mathrm{C}$ confirms a dominance of observables that are connected to job stability and employment characteristics. The approximation and reweighting errors are generally small and mostly insignificant. Overall, the mobility shifts in East and West are associated with both, changes in composition and structure.

While a detailed decomposition of structure effects is not possible without an arbitrary reference group we can test whether the coefficients of the RIF regression (cf. equation 11) changed over time. The tests (see the electronic appendix) yield that except for the regional indicators $(\mathrm{R})$ the coefficients of all factor groups changed significantly over time.

The change of observable characteristics in the East German labor market drives a substantial share of the decline in wage mobility particularly in the second half of the observation window. Job stability and employment characteristics seem to be key factors 
associated with wage mobility in East and West Germany, while labor force characteristics (Z) matter less. Before we discuss this evidence in greater detail we test its robustness.

\section{V.B. Two Robustness Tests}

We address two issues in our robustness tests, the impact of Berlin and of East-West migration. More than one fifth of the East German population resides in Berlin. Since the labor market in this metropolis may differ from the labor markets in the other, at times sparsely populated regions of East Germany we investigate whether our findings for East Germany are robust to omitting the observations employed in Berlin from the East German sample. Table III presents the results of this exercise. The first two columns show the two sub-periods and the final column shows the evidence for the entire observation window.

The descriptive evidence on the drop in wage mobility in Panel A confirms the patterns that we observed for all of East Germany. The aggregate decomposition in Panel B confirms that a substantial share of the mobility decline is associated with the composition of the sample, particularly in the second sub-period. The detailed decomposition in Panel C again shows that job stability and employment characteristics are the factors that contribute most to the composition effect. Overall, our results are robust to omitting Berlin.

The second test addresses a sample selection criterion that we imposed on the analysis. To ensure that we truly describe the East and West German labor markets we required so far that individuals are observed in the same region of the country (i.e., east or west) when we measure their wages in periods $t$ and $t+4$. This potentially generates a selectivity problem if there is migration, a phenomenon we certainly observed since the early 1990s (see, e.g., Brücker and Trübswetter 2007 or Hunt 2006): it is possible that East German wage mobility declined because workers who are mobile in their wage rank left the region. In that case the East German labor market per se may not have changed and our previous results would be biased. 
To test this scenario, we generated an alternative sample. First, we pooled the East and West German observations. Next, we accounted for the east-west difference in nominal wage censoring thresholds: we applied the 90th percentile of the East German wage distribution for consistent top coding in the full sample. ${ }^{14} \mathrm{We}$ then ranked the uncensored wage observations in our national sample. For the robustness test, we consider all individuals who work in East Germany in base year $(t)$ of the mobility measurement and describe their mobility in the national wage distribution by period $t+4$ independent of whether they are observed in East or West Germany in $t+4$. This describes the wage mobility of East German employees rather than the wage mobility in the East German labor market. ${ }^{15}$ The development of wage mobility based on the now nationally calculated ranks is presented in Appendix Figure A.6: changing from regional to national assignments of wage ranks for the original sample shifts the wage mobility observed in West Germany to higher levels, however, with a similar decline over time. The results are not affected by allowing West German emigrants back into the sample. In East Germany, the change from regional to national wage ranks reduces the observed wage mobility. When we then add East German emigrants to the sample observed mobility jumps back to the originally measured values. Based on Figure A.6 the mobility decline is robust to definitional changes.

Table IV shows the results of the decomposition exercise based on national ranks and the extended East German sample. ${ }^{16}$ The observed variances of the rank change distributions in Panel A do not differ substantially from those in Tables I and II. The overall decline in mobility is reduced from 199.1 (see Table I) to 145.11 (see column 3, Panel A, Table IV).

\footnotetext{
$14 \quad$ A number of alternative procedures could be used, each with its own strengths and weaknesses. Since the East and West German wage distributions differ any nominal cutoff censors different shares of the two regional wage distributions.

15 Eventually, at least 94.1 percent of the initial East German employees are employed in the East German labor market 4 years later. The share of East-West migrants by period $t+4$ ranged from 3.08 percent in period 1993-1997, to 5.9 percent in period 1998-2002 and 4.25 percent in 2004-2008.

16 We present the decomposition results obtained for the original sample only changing to national wage ranks in the electronic appendix. The aggregate decomposition patterns as well as the dominance of the job stability and employment factor groups in the detailed decomposition are confirmed.
} 
This decline occurs only in the early observation period; adding individual who left East Germany to the sample does not affect the development in the second observation period. The aggregate decomposition in Panel B is fairly similar to that presented in Tables I and II: structure effects dominate particularly in the first period and composition effects matter particularly in the second period. Overall, observable characteristics account for 40 percent of the mobility decline in Table I and for 47 percent in Table IV. In both analyses, the relative contribution of observable characteristics is larger in the second half of the observation period. The key results, i.e. the mobility decline and the substantial contribution of observables are robust to changes in the sample composition.

However, the patterns of the detailed decomposition presented in Panel C of Table IV differ from those in Tables I and II. When we consider the wage mobility of East German employees (see Table IV) rather than of those remaining in the East German labor market (see Tables I and II) individual characteristics account for a larger share of the observed decrease in mobility. This is not surprising given that we added East-West migrants who are known to be a selective group. However, also in the extended sample job stability and employment characteristics remain important factors which jointly explain most of the aggregate composition effect. Therefore, the results in Table IV confirm the robustness of prior findings to changes in the sample composition.

\section{V.C. Discussion}

We have learnt that East German wage mobility was high initially after German unification and rapidly fell below West German wage mobility, which also has been declining over time. A share of about 40 percent of the overall East German mobility decline between 1993 and 2004 is associated with shifts in observables (composition effect) and a share of about 60 percent is connected to correlation patterns and unobservables (structure effect). The structure effect drives the initial fast drop in wage mobility in the first half of the observed 
period (1993-1998), when matching and remuneration mechanisms were to be established in the East German labor market. In the second half of the observation period (1998-2004) predominantly composition effects contribute to the East German mobility decline.

We find that neither migration nor shifting workforce characteristics such as the age structure drive the mobility decline or even just the composition effect. Instead, changes in job stability and employment characteristics are behind most of the composition effect in both periods and regions of the country. The development of regional job stability indicators $(J)$ (see the electronic appendix) documents the stabilization of the East German labor market: the share of individuals changing employers declines to West Germans levels; unemployment experience still differs between the regions, but declined in East Germany; the accumulation of job tenure in East Germany took time, however, by 2004 the share of employees with at least two years of tenure has about reached the West German level. Similarly, the incidence of changes in occupation and industry converged between both regions over time.

So, indeed, observable characteristics reflect adjustments in the East German labor market, in particular its rising job stability. This, however, does not explain why East German wage mobility has fallen below West German levels. Future research may address this phenomenon.

\section{CONCLUSIONS}

This is one of the first studies using a large and long-running administrative dataset to study the development of wage mobility over time. We describe the case of Germany since the mid 1970s: wage mobility in West Germany was initially stable and declined since the late 1990s, wage mobility in East Germany declined continuously since the early 1990s. We discuss different explanations of the observed phenomenon and empirically quantify their contribution. We apply a decomposition procedure that is based on recentered influence functions (RIF). The results yield that a share of about 40 percent of the mobility decline in 
East Germany is associated with changes in observable characteristics, particularly those describing job stability and employment characteristics. In addition, structural shifts and unexplained factors contributed to the decline in wage mobility in both parts of Germany.

The ongoing changes in West German wage structures suggest that the transition process in the former socialist East German labor market cannot be interpreted as a convergence to a static and possibly institution-driven German wage structure. Instead, wage mobility appears to be a dynamic feature of modern labor markets.

A recent literature started to discuss institutional determinants of wage flexibility. Cardoso (2006) compared wage mobility in a strictly regulated and in a flexible labor market, i.e. in Portugal and the United Kingdom. She concludes that not aggregate institutional differences but firm level conditions shape mobility outcomes. In contrast, Cappellari (2010) and earlier Gottschalk (1997) suggest that wage flexibility is associated with labor market flexibility. We find substantial differences in wage mobility at similar levels of labor market rigidity for our two regional subsamples and at different points in time. Also, among our key contributors to the explanation of mobility changes are micro-level indicators of job stability and employment characteristics. Therefore, our evidence appears to support the conclusions of Cardoso (2006) that wage mobility is not determined at the aggregate level.

An important conclusion of our analysis is that the welfare effects of the observed rise in wage inequality are not balanced by higher life-time wage mobility, as was suggested by Friedman (1962); he interpreted mobility as an equalizer of long-term incomes. Instead, inequality continues to rise at the same time as its potential balancing mechanism-wage mobility—loses effectiveness.

\section{UNIVERSITY ERLANGEN-NUREMBERG}

\section{DIW BERLIN}




\section{REFERENCES}

Aaberge, Rolf, Anders Björklund, Markus Jäntti, Mårten Palme, Peder J. Perdersen, Nina Smith, and Tom Wennemo, 2002, Income Inequality and Income Mobility in the Scandinavian Countries Compared to the United States, Review of Income and Wealth 48(4), 443-469.

Abowd, John M., and David Card, 1989, On the Covariance Structure of Earnings and Hours Changes, Econometrica 57(2), 411-445.

Anger, Silke, 2011, The Cyclicality of Effective Wages within Employer-Employee Matches in a Rigid Labor Market, Labour Economics 18(6), 786-797.

Antonczyk, Dirk, Bernd Fitzenberger, and Katrin Sommerfeld, 2010, Rising wage inequality, the decline of collective bargaining, and the gender wage gap, Labour Economics $17(5), 835-847$.

Auten, Gerald and Geoffrey Gee, 2009, Income Mobility in the United States: New Evidence from Income Tax Data, National Tax Journal 62(2), 301-328.

Ayala, Luis and Mercedes Sastre, 2008, The structure of income mobility: empirical evidence from five UE countries, Empirical Economics 35(3), 451-473.

Baker, Michael, 1997, Growth-Rate Heterogeneity and the Covariance Structure of LifeCycle Earnings, Journal of Labor Economics 15(2), 338-375.

Bartels, Charlotte and Timm Bönke, 2010, German male income volatility 1984 to 2008: Trends in permanent and transitory income components and the role of the welfare state, School of Business \& Economics DP 2010 / 18, Freie Universität Berlin, Berlin.

Bayaz-Ozturk, Gulgun, Richard V. Burkhauser, and Kenneth A. Couch, 2011, Different Directions: Economic Mobility in The Western States of Germany and the U.S. from 1984-2006, mimeo, Cornell University.

Bönke, Timm, Giacomo Corneo, and Holger Lüthen, 2011, Lifetime Earnings Inequality in Germany, IZA Discussion Paper No. 6020, Bonn.

Brücker, Herbert and Parvati Trübswetter, 2007, Do the best go west? An analysis of selfselection of employed east-west migrants in Germany, Empirica 34(4), 371-395.

Buchinsky, Moshe and Jennifer Hunt, 1999, Wage Mobility in the United States, Review of Economics and Statistics 81(3), 351-368.

Buchinsky, Moshe, Gary Fields, Denis Fougère, and Francis Kramarz, 2003, Francs or Ranks? Earnings Mobility in France, 1967-1999, CEPR Discussion Paper No. 3937, London.

Burkhauser, Richard V., Douglas Holtz-Eakin, and Stephen E. Rhody, 1997, Labor Earnings Mobility and Inequality in the United States and Germany During the Growth Years of the 1980s, International Economic Review 38(4), 775-794.

Burkhauser, Richard V. and John G. Poupore, 1997, A Cross-National Comparison of Permanent Inequality in the United States and Germany, Review of Economics and Statistics 79(1), 10-17.

Burkhauser, Richard V., Shuaizhang Feng, and Stephen P. Jenkins, 2009, Using the P90/P10 Index to Measure U.S. Inequality Trends with Current Population Survey Data: A View from Inside the Census Bureau Vaults, Review of Income and Wealth 55(1), 166-185.

Burkhauser, Richard V., Shuaizhang Feng, Stephen P. Jenkins, and Jeff Larrimore, 2011, Estimating trends in US income inequality using the Current Population Survey: the importance of controlling for censoring, Journal of Economic Inequality 9(3), 393415.

Cappellari, Lorenzo, 2010, Labour Turnover and Wage Mobility: The Impact of the Legal Setting and Institutions, in: Marsden, David and Francois Rycx (eds.), Wage Structures, Employment Adjustments and Globalization, Palgrave Macmillan, pp. 1736. 
Cardoso, Ana Rute, 2006, Wage mobility: do institutions make a difference? Labour Economics 13(3), 387-404.

Chen, Wen-Hao, 2009, Cross-National Differences in Income Mobility: Evidence from Canada, the United States, Great Britain, and Germany, Review of Income and Wealth 55(1), 75-100.

Comin, Diego, Erica L. Groshen, Bess Rabin, 2009, Turbulent Firms, Turbulent Wages? Journal of Monetary Economics 56(1), 109-133.

Dahl, Molly, Thomas DeLeire, and Jonathan Schwabish, 2011, Estimates of Year-to-Year Volatility in Earnings and Household Incomes from Administrative Survey, and Matched Data, Journal of Human Resources 46(4), 750-773.

Dickens, Richard, 2000, Caught in a Trap? Wage Mobility in Great Britain: 1975-1994, Economica 67(268), 477-497.

DiNardo, John, Nicole M. Fortin, and Thomas Lemieux, 1996, Labor Market Institutions and the Distribution of Wages, 1973-1992: A Seminparametric Approach, Econometrica 64(5), 1001-1044.

Drewianka, Scott, 2010, Cross-Sectional Variation in Individuals' Earnings Instability, Review of Income and Wealth 56(2), 291-326.

Dustmann, Christian, Johannes Ludsteck, and Uta Schönberg, 2009, Revisiting the German Wage Structure, Quarterly Journal of Economics 124(2), 843-881.

Farber, Henry S., 2007, Is the Company Man an Anachronism? Trends in Long-Term Employment in the United States, 1973-2006, in: Danziger, Sheldon and Cecilia Elena Rouse (eds.), The Price of Independence: The Economics of Early Adulthood, New York, Russell Sage Foundation, 56-83.

Farber, Henry, S., 2008, Employment Insecurity: The Decline in Worker-Firm Attachment in the United States, Princeton University Industrial Relations Section Working Paper No. 530, Princeton.

Fields, Gary S. and Efe A. Ok, 1996, The Meaning and Measurement of Income Mobility, Journal of Economic Theory 71(2), 349-377.

Fields, Gary S. and Efe A. Ok, 1999a, The Measurement of Income Mobility: An Introduction to the Literature, in: Silber, Jacques (ed.), Handbook on Income Inequality Measurement, Kluwer Academic Publishers, Boston, 557-596.

Fields, Gary S. and Efe A. Ok, 1999b, Measuring Movement of Incomes, Economica 66(264), 455-472.

Finnie, Ross and David Gray, 2002, Earnings dynamics in Canada: an econometric analysis, Labour Economics 9(6), 763-800.

Firpo, Sergio, Nicole M. Fortin, and Thomas Lemieux, 2007, Decomposing Wage Distributions using Recentered Influence Regressions, mimeo, University of British Columbia.

Firpo, Sergio, Nicole M. Fortin, and Thomas Lemieux, 2009, Unconditional Quantile Regressions, Econometrica 77(3), 953-973.

Firpo, Sergio, Nicole M. Fortin, and Thomas Lemieux, 2011, Occupational Tasks and Changes in the Wage Structure, mimeo, University of British Columbia.

Fortin, Nicole, Thomas Lemieux, and Sergio Firpo, 2011, Decomposition Methods in Economics, in: Ashenfelter, Orley and David Card (eds.), Handbooks of Labor Economics Vol. 4A, Elsevier B.V., San Diego and Amsterdam, Chapter 1, 1-102.

Friedman, Milton, 1962, Capitalism and Freedom, Chicago University Press, Chicago.

Fuchs-Schündeln, Nicola and Matthias Schündeln, 2009, Who Stays, who goes, and who returns? East-West migration within Germany since reunification, Economics of Transition 17(4), 703-738. 
Fuchs-Schündeln, Nicola, Dirk Krueger, and Mathias Sommer, 2010, Inequality trends for Germany in the last two decades: A tale of two countries, Review of Economic Dynamics 13(1), 103-132.

Gernandt, Johannes, 2009, Decreasing Wage Mobility in Germany, ZEW Discussion Paper No. 09-04, Mannheim.

Gottschalk, Peter, 1997, Inequality, Income Growth, and Mobility: The Basic Facts, Journal of Economic Perspectives 11(2), 21-40.

Gottschalk, Peter and Robert Moffitt, 1994, The Growth of Earnings Instability in the U.S. Labor Market, Brookings Papers on Economic Activity 1994(2), 217-272.

Gottschalk, Peter and Robert Moffitt, 2009, The Rising Instability of U.S. Earnings, Journal of Economic Perspectives 23(4), 3-24.

Gottschalk, Peter and Enrico Spolaore, 2002, On the Evaluation of Economic Mobility, Review of Economic Studies 69(1), 191-208.

Gottschalk, Peter and Minh Huynh, 2010, Are Earnings Inequality and Mobility Overstated? the Impact of Non-Classical Measurement Error, Review of Economics and Statistics 92(2), 302-315.

Gregg, Paul and Claudia Vittori, 2008, Exploring Shorrocks Mobility Indices Using European Data, CMPO Working Paper Series No. 08/206, Bristol.

Hanel, Barbara and Regina T. Riphahn, 2011, The Employment of Mothers - Recent Developments and their Determinants in East and West Germany, forthcoming: Journal of Economics and Statistics (Jahrbücher für Nationalökonomie und Statistik).

Hauser, Richard and Holger Fabig, 1999, Labor Earnings and Household Income Mobility in Reunified Germany: A Comparison of the Eastern and Western States, Review of Income and Wealth 45(3), 303-324.

Hofer, Helmut and Andrea Weber, 2002, Wage mobility in Austria 1986-1996, Labour Economics 9(4), 563-577.

Hunt, Jennifer, 2001, Post-Unification Wage Growth in East Germany, Review of Economics and Statistics 83(1), 190-196.

Hunt, Jennifer, 2006, Staunching Emigration from East Germany: Age and the Determinants of Migration, Journal of the European Economic Association 4(5), 1014-1037.

Jarvis, Sarah and Stephen P. Jenkins, 1998, How Much Income Mobility is there in Britain? The Economic Journal 108(447), 428-443.

Jenkins, Stephen P., 2011, Changing fortunes: income mobility and poverty dynamics in Britain, Oxford University Press, Oxford.

Jenkins, Stephen P. and Philippe van Kerm, 2006, Trends in income inequality, pro-poor income growth, and income mobility, Oxford Economic Papers 58(3), 531-548.

Kohn, Karsten and Dirk Antonczyk, 2011, The Aftermath of Reunification: Sectoral Transition, Gender, and Rising Wage Inequality in East Germany, IZA Discussion Paper No. 5708, Bonn.

Kopczuk, Wojciech, Emmanuel Saez, and Jae Song, 2010, Earnings Inequality and Mobility in the United States: Evidence from Social Security Data since 1937, Quarterly Journal of Economics 125(1), 91-128.

Lechner, Michael, 2001, The Empirical Analysis of East German Fertility after Unification: An Update, European Journal of Population 17(1), 61-74.

Lillard, Lee A. and Robert J. Willis, 1978, Dynamic Aspects of Earning Mobility, Econometrica 46(5), 985-1012.

Lillard, Lee A. and Yoram Weiss, 1979, Components of Variation in Panel Earnings Data: American Scientists 1960-1970, Econometrica 47(2), 437-454.

Maasoumi, Esfandiar and Mark Trede, 2001, Comparing Income Mobility in Germany and the United States Using Generalized Entropy Mobility Measures, Review of Economics and Statistics 83(3), 551-559. 
MaCurdy, Thomas E., 1982, The Use of Time Series Processes to Model the Error Structure of Earnings in a Longitudinal Data Analysis, Journal of Econometrics 18(1), 83-114.

Meghir, Costas and Luigi Pistaferri, 2004, Income Variance Dynamics and Heterogeneity, Econometrica 72(1), 1-32.

Meghir, Costas and Luigi Pistaferri, 2010, Earnings, Consumption, and Lifecycle Choices, NBER Working Paper Series No. 15914, Cambridge Mass.

OECD, 1997, Earnings mobility: taking a longer run view, Employment Outlook, 27-61, Paris.

Raferzeder, Thomas and Rudolf Winter-Ebmer, 2007, Who is on the rise in Austria: Wage mobility and mobility risk, Journal of Economic Inequality 5(1), 39-51.

Riphahn, Regina T. and Parvati Trübswetter, 2011, The intergenerational transmission of educational attainment in East and West Germany, IAB Discussion Paper No. 4751, Nuremberg.

Sabelhaus, John and Jae Song, 2010, The great moderation in micro labor earnings, Journal of Monetary Economics 57, 391-403.

Schmillen, Achim and Joachim Möller, 2010, Determinants of Lifetime Unemployment: A Micro Data Analysis with Censored Quantile Regressions, forthcoming: Labour Economics.

Shin, Donggyun and Gary Solon, 2011, Trends in Men's Earnings Volatility: What does the Panel Study of Income Dynamics Show?, Journal of Public Economics 95(7-8), 973982.

Shorrocks, Anthony F., 1978, Income Inequality and Income Mobility, Journal of Economic Theory 19(2), 376-393.

Stephen, Silvia J. and Wolfgang Schroeder, 2007, Why are German Employers Associations Declining?, Comparative Political Studies 40(12), 1433-1459.

Stevens, Ann Huff, 2001, Changes in Earnings Instability and Job Loss, Industrial and Labor Relations Review 55(1), 60-78.

van Kerm, Philippe, 2003, On the Magnitude of Income Mobility in Germany, Schmollers Jahrbuch (Journal of Applied Social Science Studies) 123(1), 15-26.

van Kerm, Philippe, 2004, What Lies Behind Income Mobility? Reranking and Distributional Changes in Belgium, Western Germany, and the USA, Economica 71(282), 223-239.

van Kerm, Philippe, 2006, Comparisons of Income Mobility Profiles, ISER Working Paper No. 2006-36, Colchester.

Wanger, Susanne, 2006, Erwerbstätigkeit, Arbeitszeit und Arbeitsvolumen nach Geschlecht und Altersgruppen, IAB Forschungsbericht Nr. 2/2006, Nürnberg. 
FIGURE I

Development of Percentiles of the Real Wage Distribution by Region
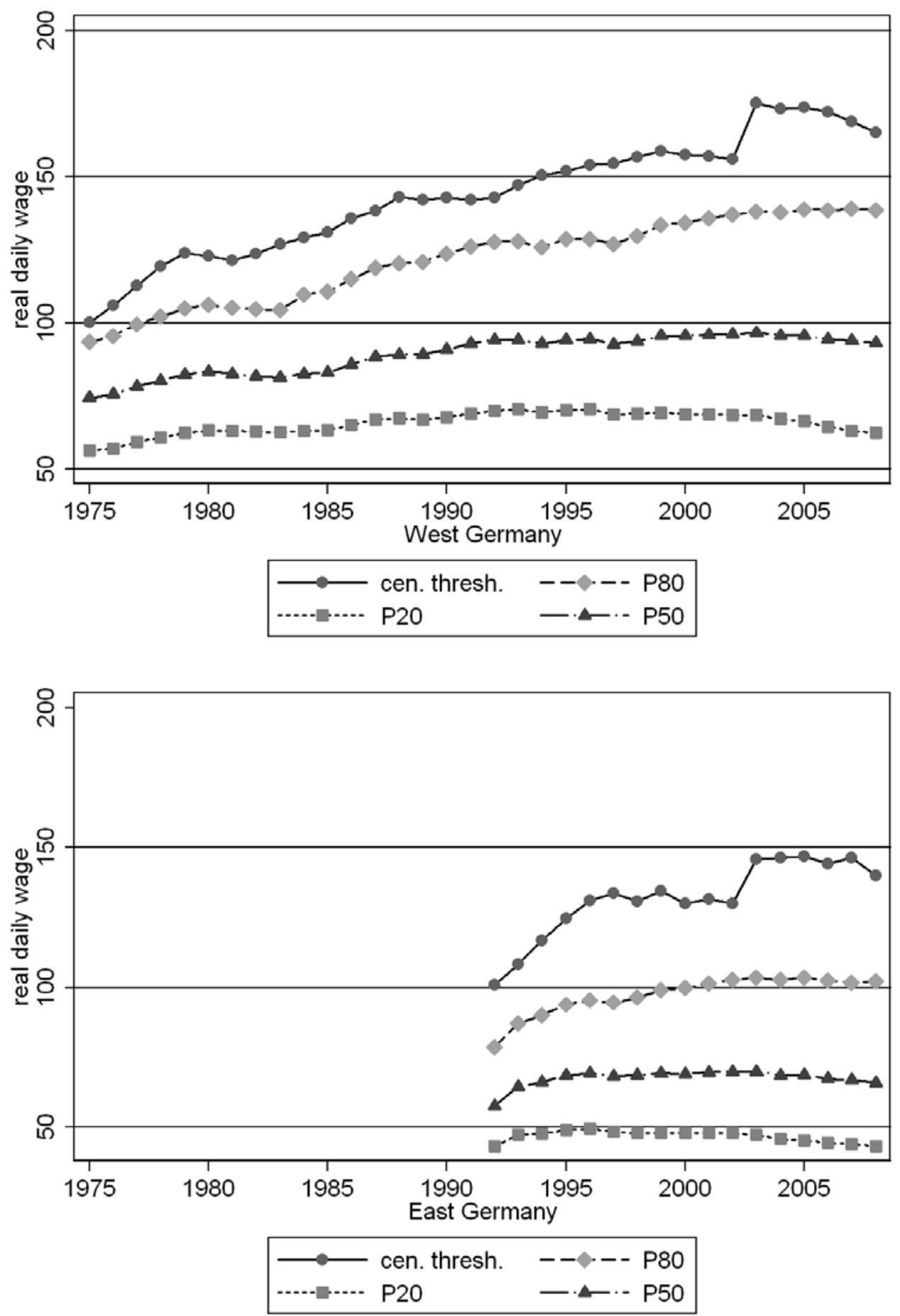

Notes: All figures present the 20th (P20), 50th (P50), and 80th (P80) percentile of the distribution of daily real wages separately in West and East Germany. In addition, the censoring threshold for insurance contributions (cen. thresh.) is depicted.

Source: SIAB (1975-2008). 
FIGURE II.A

Development of Real Daily Wage Inequality in East and West Germany: Gini Coefficients and Mean Log Deviation (MLD)

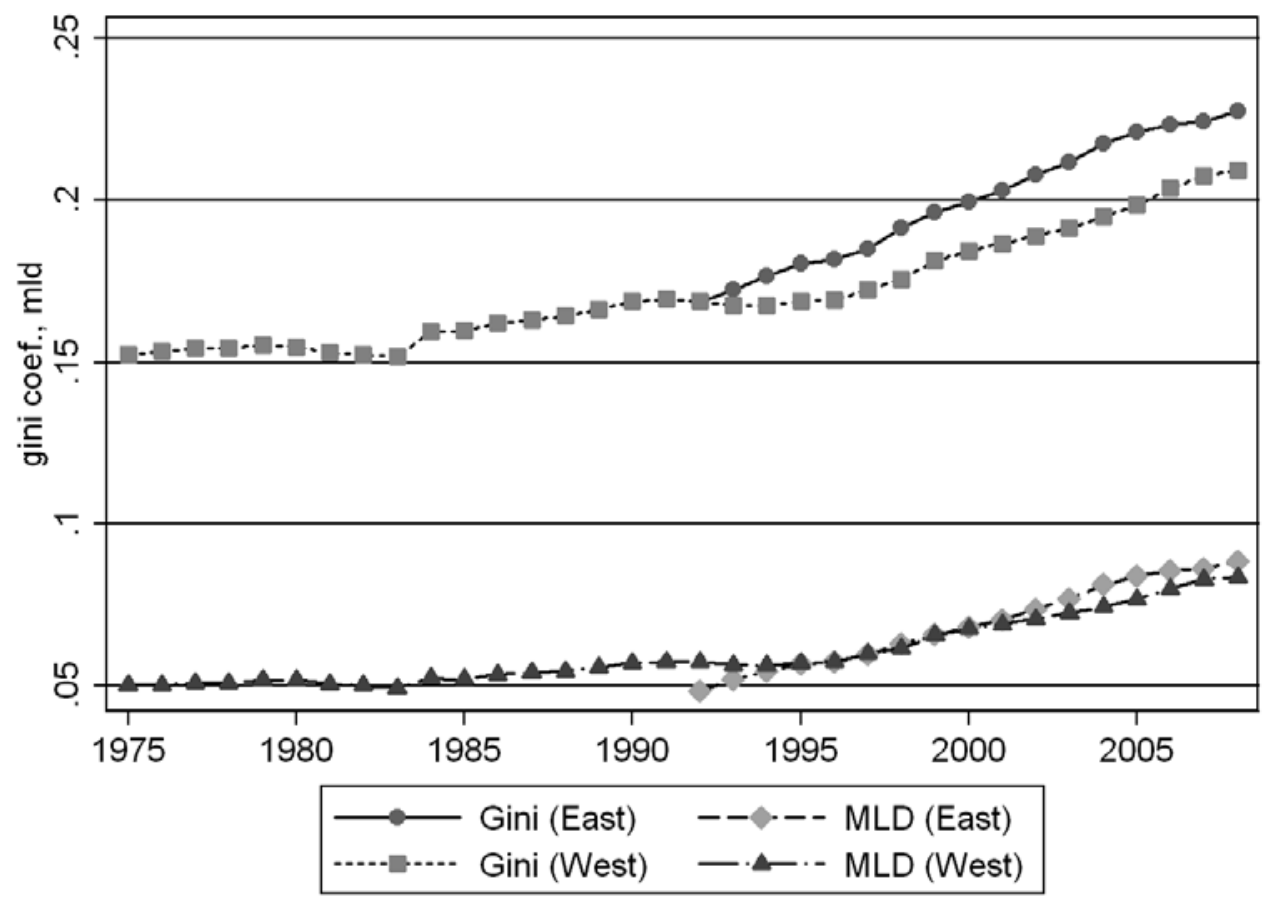

FIGURE II.B

Development of the Spread between 80th and 20th Percentile of the Real Wage Distribution

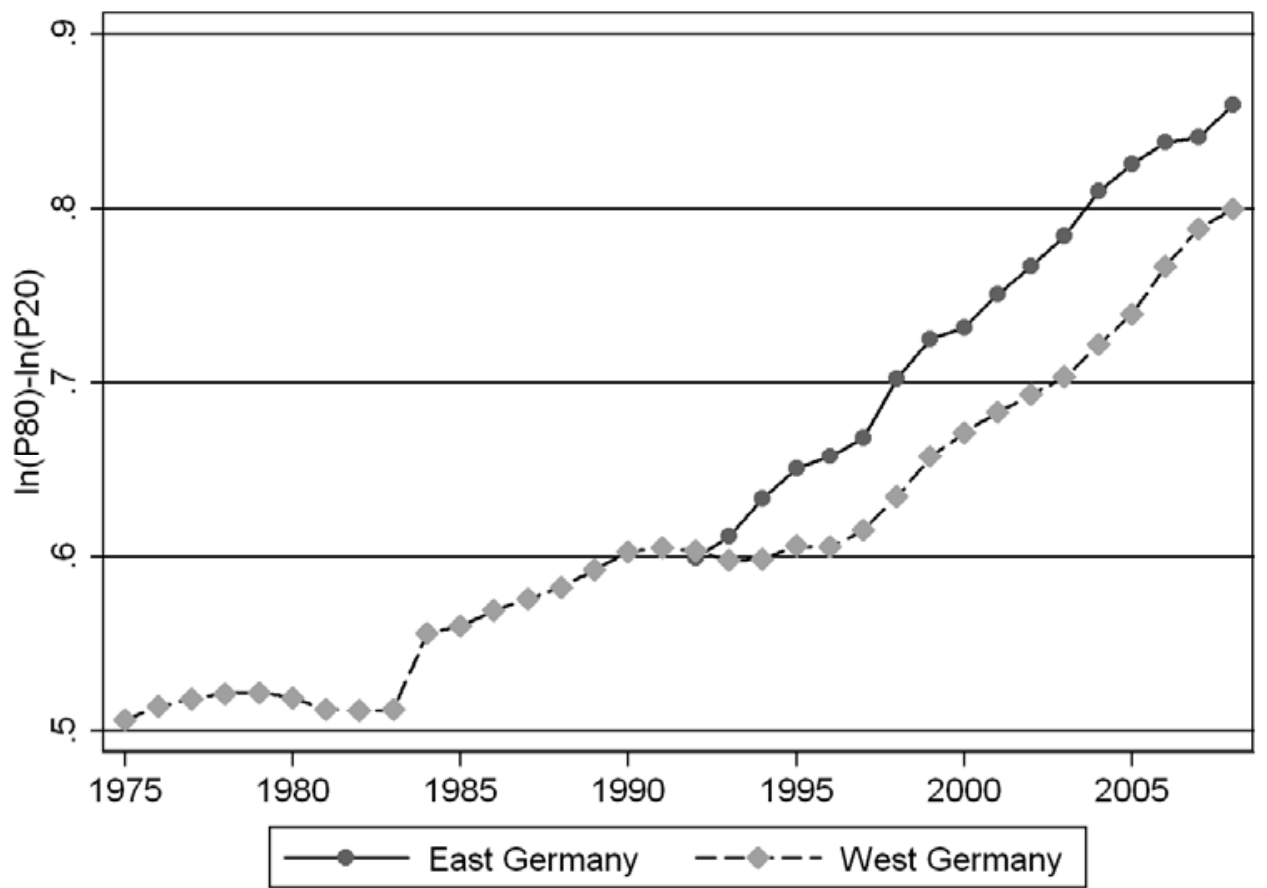

Notes: The Gini measures are calculated for the uncensored part of the distribution of real daily wages only.

Source: SIAB (1975-2008). 
FIGURE III

Development of Quintile Transition Probabilities by Region
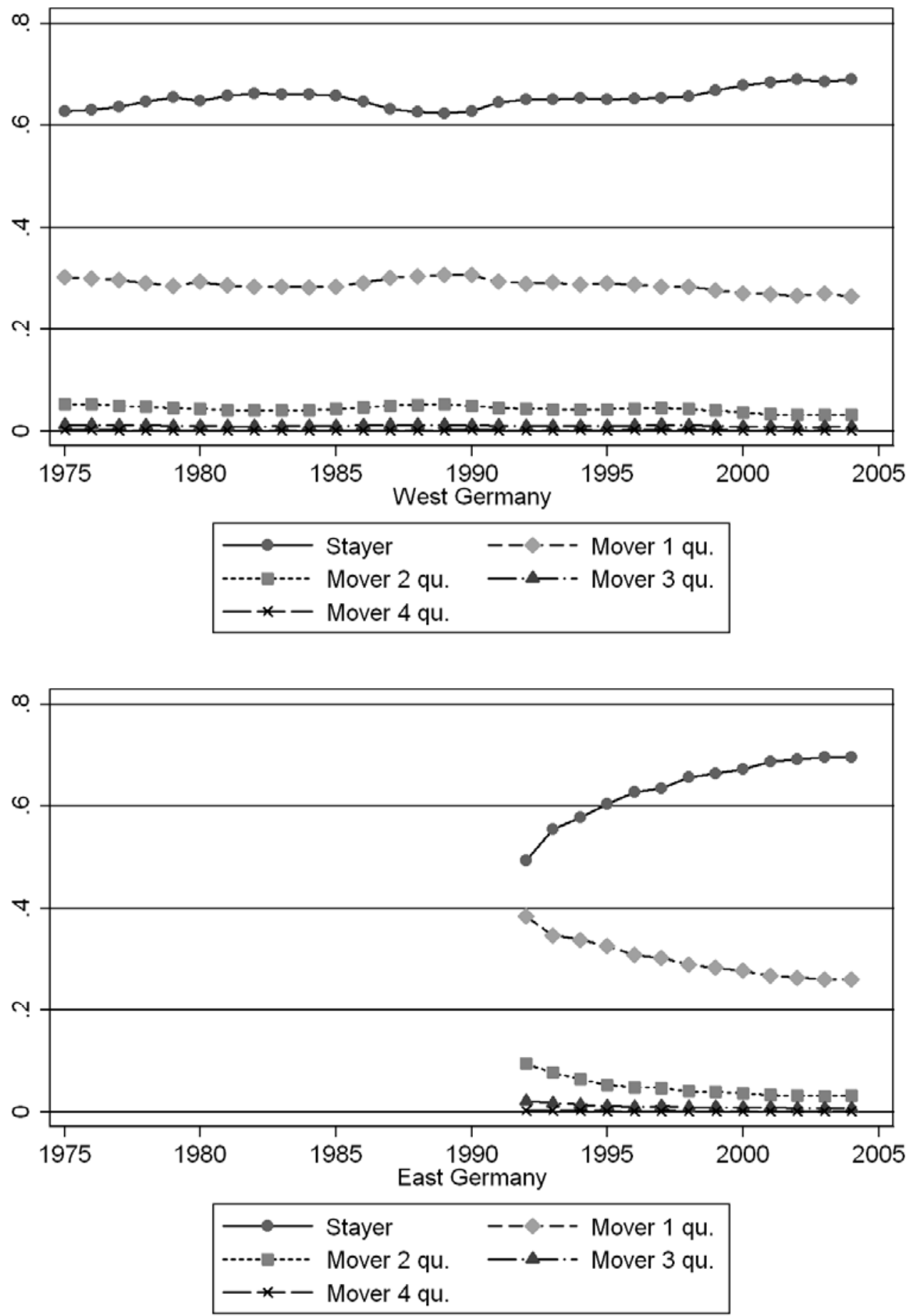

Notes: All figures present the probability of a transition from a given quintile in the quintile transition matrix of year $t$ (x-axis) to year $t+4$. Rank positions and transition matrices are calculated based on separate East and West German wage distributions in each year ( $t$ and $t+4)$. The graphs indicate the probability of staying in a given quintile, of jumping by one, two, three, or four quintiles. Upward and downward mobility are not distinguished. All observations - including censored observations - are considered.

Source: SIAB (1975-2008). 
FIGURE IV

Development of the Probability of a Change in Rank Position by More Than 10 Points

Between $t$ and $t+4$

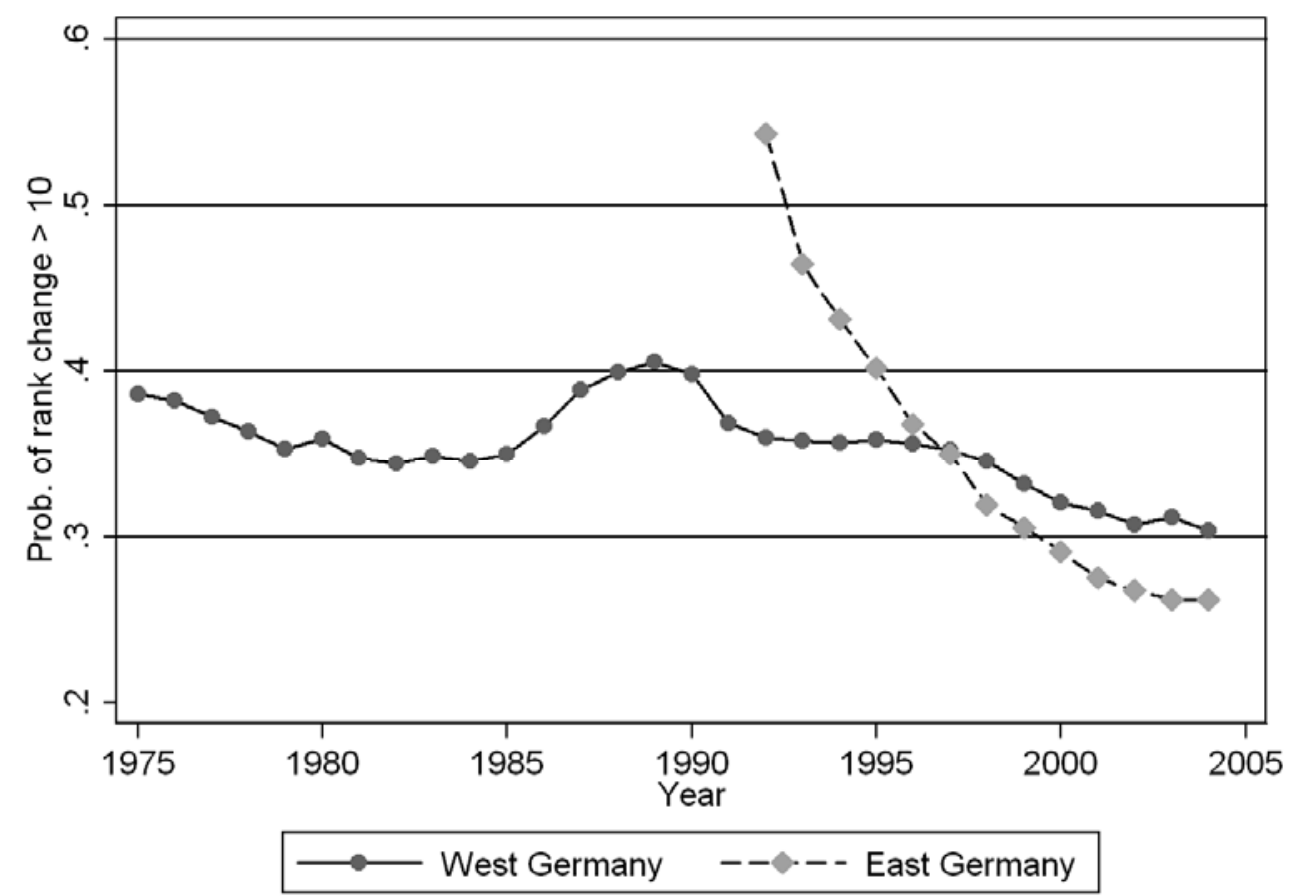

Notes: Calculated using rank distributions based only on uncensored observations because censored observations do not change their measurable rank position over time.

Source: SIAB (1975-2008). 
FIGURE V

Distribution of Changes in Relative Rank Positions - by Period and Region
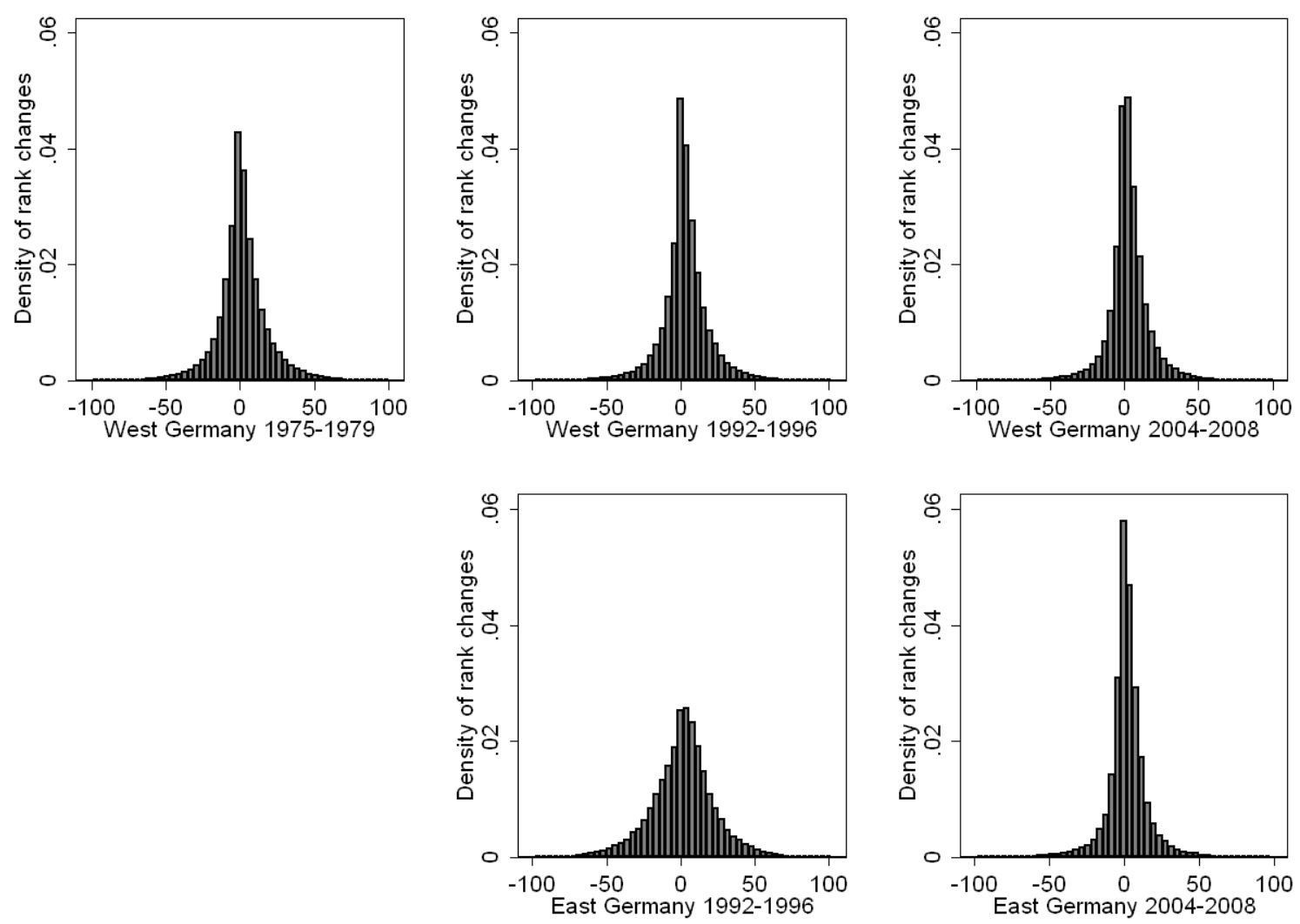

Notes: Individual rank positions are determined based on the regional wage distribution in both, the beginning and the end years of the considered intervals. Since not all wage earners of the base year are observed four years later, and because those with stable employment situations may represent a positive selection, we obtain slightly more upward than downward mobility in rank positions. Censored wage observations are omitted: because all censored individuals occupy the same rank, their consideration would vastly increase the share of zero changes in rank position. Alternative depictions including censored wage observations are available upon request.

Source: SIAB (1975-2008). 
FIGURE VI

Development of Correlation Coefficients for Individuals' Percentile Ranks
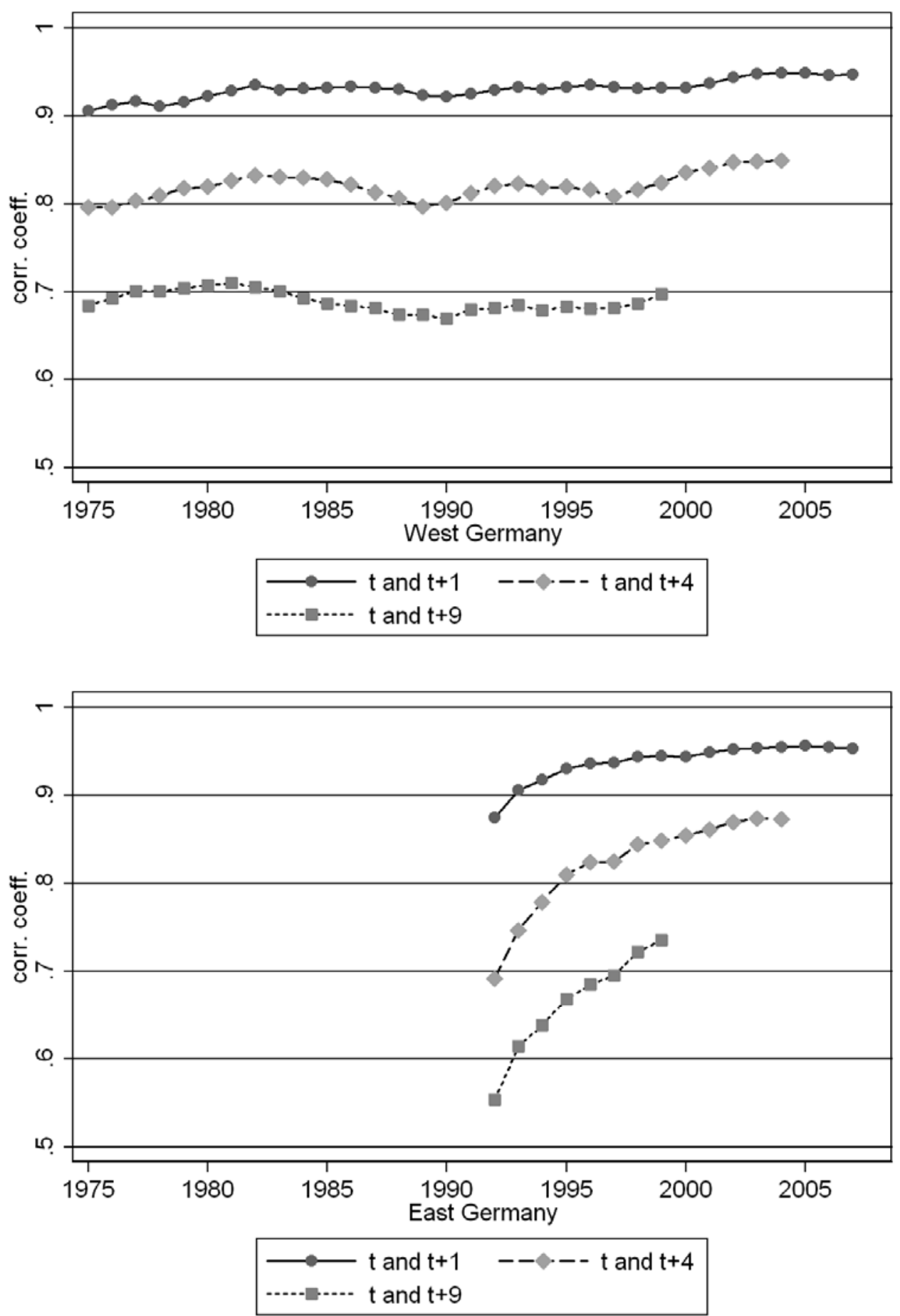

Notes: These figures describe correlation coefficients at the individual level measured based on subsequent base years (x-axis). The correlation coefficients were calculated including the wages of censored observations. Since the last year of observed data is 2008 we cannot calculate more recent correlations so far.

Source: SIAB (1975-2008). 
FIGURE VII

Development of Shorrocks Indices Based on Mean Log Deviation and Gini Coefficients for Regional Subsamples

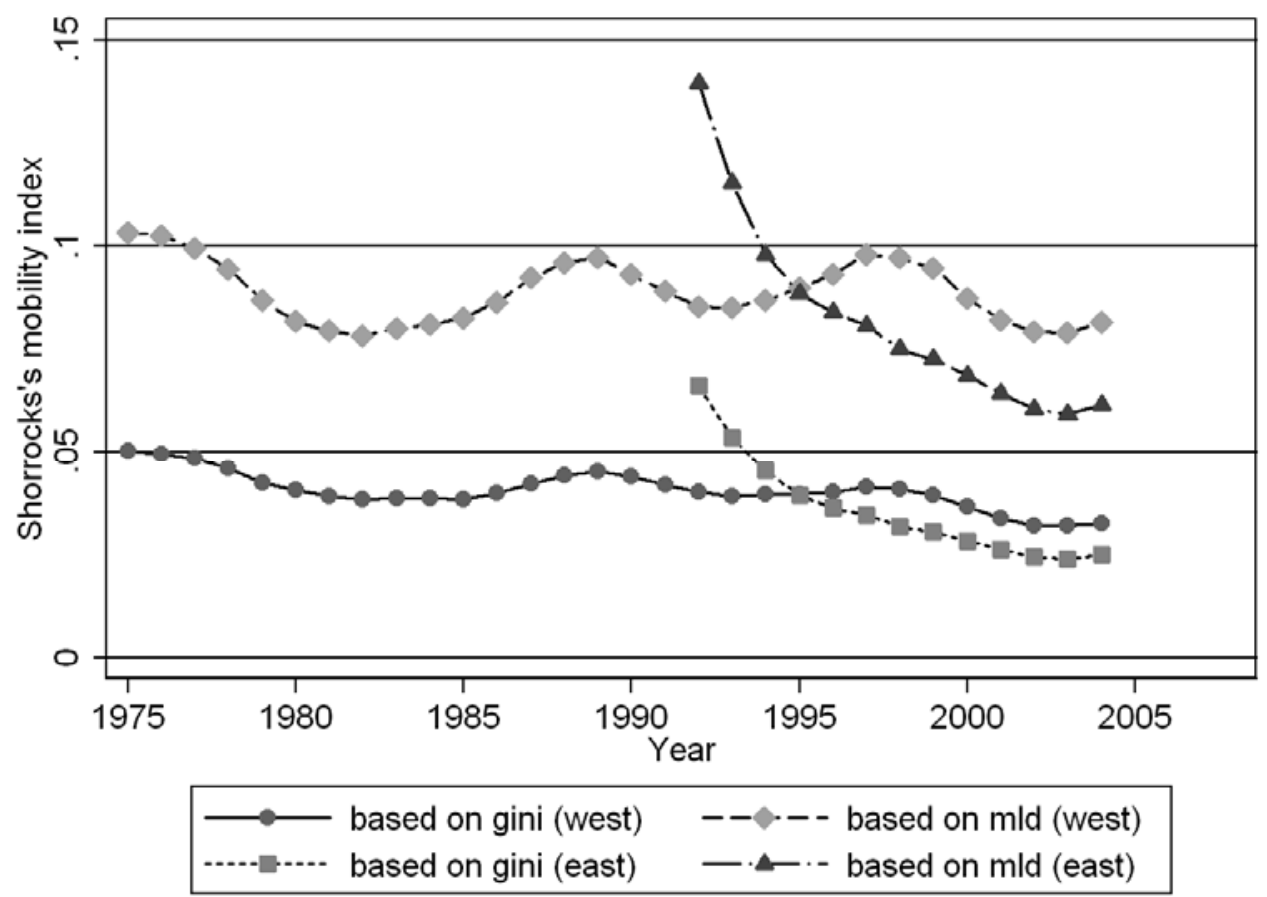

Notes: All values are calculated for an accounting period of five years (i.e., years $t-t+4$ ). The calculations use only the uncensored part of the wage distribution. Indicators labeled "mld" present the Shorrocks index when using a mean log deviation inequality measure. Indicators labeled "gini" are based on the gini coefficient as an inequality measure.

Source: SIAB (1975-2008). 
FIGURE VIII

Development of Annual Mean Values of Dependent Variable by Region

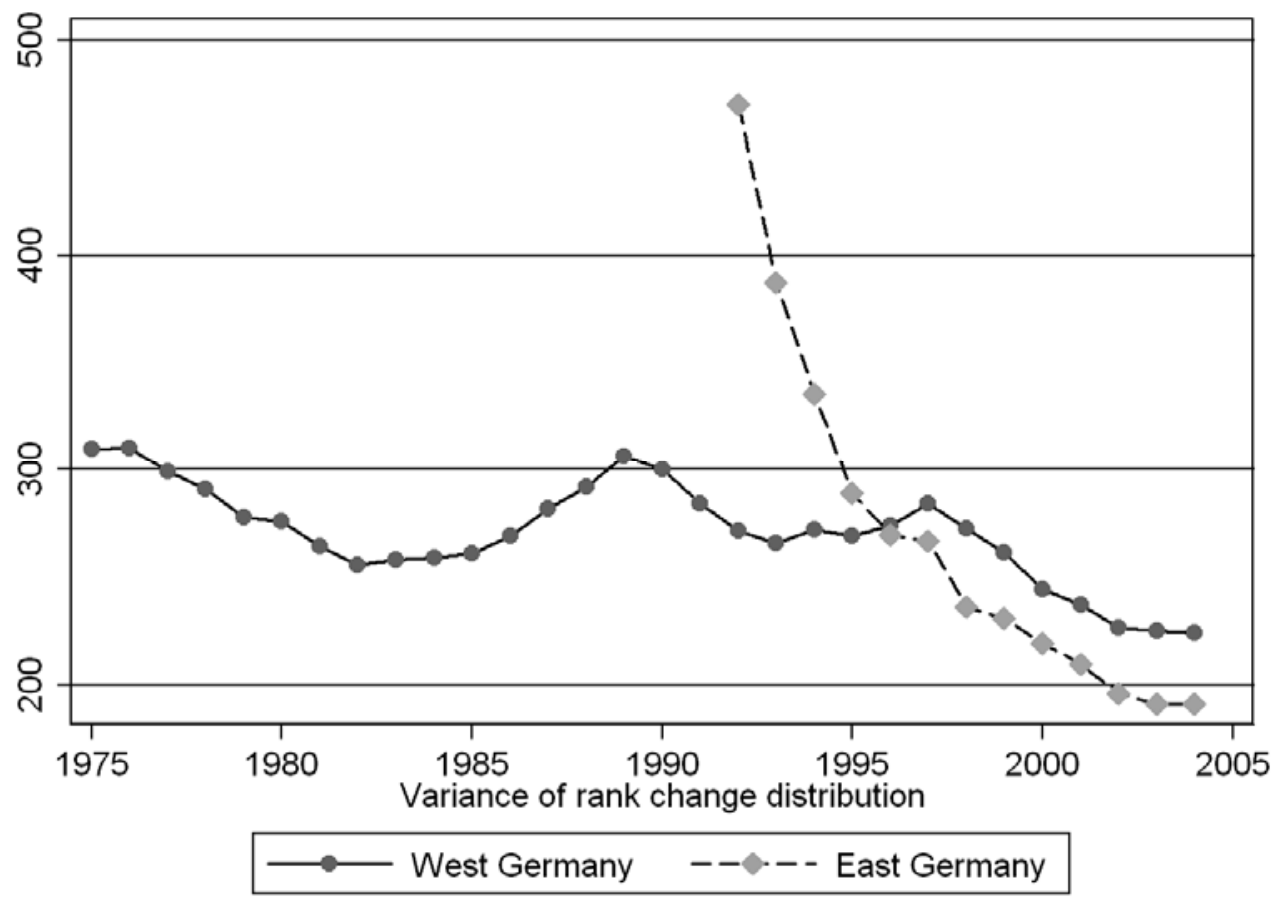

Notes: The dependent variable of the empirical decomposition analyses describes the individual contribution to the variance of the distribution of individual rank changes in the annual wage distributions between periods $t$ (on the $\mathrm{x}$-axis) and $t+4$.

Source: SIAB (1975-2008). 
TABLE I

DECOMPOSITION RESUlTS - FULL PERIOD

\begin{tabular}{lcc} 
period 1 & $1993-1997$ & $1993-1997$ \\
period 0 & $2004-2008$ & $2004-2008$ \\
& East & West \\
\hline \hline
\end{tabular}

$\begin{array}{lcc}\text { A. Description } & \\ \text { period } 1 & 390.19^{\star \star \star} & 265.70^{\star \star \star} \\ & (2.90) & (1.40) \\ \text { period } 0 & 191.09^{\star \star \star} & 224.39^{\star \star \star} \\ & (2.78) & (1.46) \\ \text { change } & -199.10^{\star \star \star} & -41.31^{\star \star \star} \\ & (4.09) & (2.12)\end{array}$

B. Aggregate Decomposition

$\begin{array}{lcc}\text { composition } & -80.25^{\star \star \star} & 2.00 \\ & (5.16) & (1.97) \\ \text { structure } & -138.97^{\star \star \star} & -37.62 \\ & (6.27) & (2.12)\end{array}$

C. Detailed Decomposition of Composition Effect

$\begin{array}{lcc}\text { Z - individual } & -13.37^{\star \star \star} & -6.03 \\ & (3.80) & (0.82) \\ \text { J - job stability } & -32.55^{\star \star \star} & 2.31 \\ & (2.61) & (0.78) \\ \text { E - employment } & -33.08^{\star \star \star} & 5.83 \\ & (3.09) & (1.10) \\ \text { R - regional } & -1.25 \star \star \star & -0.12 \\ & (0.40) & (0.10) \\ \text { approximation error } & 0.94 & -5.31 \star \star \\ & (9.20) & (2.16) \\ \text { reweighting error } & 19.18 * \star \star & -0.38 \\ & (4.45) & (0.78)\end{array}$

Notes: $Z, J, E$, and $R$ represent the groups of individual, job stability, employment and regional variables, which contain different numbers of indicators as described in the text and electronic appendix. The figures present absolute values of mobility and their changes. The smaller font figures in italics are bootstrapped standard errors (100 replications). ***,** and * indicate statistical significance at the 1,5 , and 10 percent level, respectively. The analysis is based on the consistently censored part of the daily wage distribution. Number of observations: East Germany 1993-1997: 60,676; East Germany 2004-2008: 46,341; West Germany 1993-1997: 189,533; West Germany 2004-2008: 184,846.

Source: SIAB (1975-2008). 
TABLE II

DeCOMPOSITION Results - PARTIAL PERIODS

\begin{tabular}{|c|c|c|c|c|}
\hline \multirow{3}{*}{$\begin{array}{l}\text { period } 1 \\
\text { period } 0\end{array}$} & 1993-1997 & 1998-2002 & 1993-1997 & 1998-2002 \\
\hline & 1998-2002 & & & \\
\hline & East & & \multicolumn{2}{|c|}{ West } \\
\hline \multicolumn{5}{|l|}{$\begin{array}{l}\text { A. Description } \\
\text { period } 1\end{array}$} \\
\hline period 1 & $\begin{array}{l}390.19^{\star \star \star} \\
(3.12)\end{array}$ & $\begin{array}{l}238.611^{\star * \star} \\
(2.78)\end{array}$ & $\begin{array}{l}265.70 \text { *** } \\
(1.54)\end{array}$ & $\begin{array}{l}272.78^{\star \star \star \star} \\
(1.51)\end{array}$ \\
\hline period 0 & $\begin{array}{l}238.61 * * * \\
(2.90)\end{array}$ & $\begin{array}{l}191.09 \text { *** } \\
(2.58)\end{array}$ & $\begin{array}{l}272.78^{* \star *} \\
(1.71)\end{array}$ & $\begin{array}{l}224.39 \text { *** } \\
(1.23)\end{array}$ \\
\hline change & $\begin{array}{c}-151.58 \text { *** } \\
(4.41) \\
\end{array}$ & $\begin{array}{l}-47.52 \text { *** } \\
(4.11)\end{array}$ & $\begin{array}{l}7.08 \text { *** } \\
(2.44)\end{array}$ & $\begin{array}{l}-48.39 \\
(1.79)\end{array}$ \\
\hline \multicolumn{5}{|c|}{ B. Aggregate Decomposition } \\
\hline composition & $\begin{array}{l}-36.57 * * * \\
(2.94)\end{array}$ & $\begin{array}{l}-33.09 \text { *** } \\
(3.66)\end{array}$ & $\begin{array}{l}17.86^{* * *} \\
(1.44)\end{array}$ & $\begin{array}{l}-19.26^{* * *} \\
(1.81)\end{array}$ \\
\hline structure & $\begin{array}{c}-113.54 * * * \\
(4.48)\end{array}$ & $\begin{array}{l}-21.45^{\star * *} \\
(4.53)\end{array}$ & $\begin{array}{l}-8.57 * * * \\
(2.29)\end{array}$ & $\begin{array}{l}-26.21 \text { *** } \\
(2.20)\end{array}$ \\
\hline \multicolumn{5}{|c|}{ C. Detailed Decomposition of Composition Effect } \\
\hline Z - individual & $\begin{array}{l}-7.44^{\star * *} \\
(1.18)\end{array}$ & $\begin{array}{l}-8.71 * * * \\
(2.22)\end{array}$ & $\begin{array}{l}-4.85^{* * *} \\
(0.52)\end{array}$ & $\begin{array}{l}-4.83^{* * *} \\
(0.50)\end{array}$ \\
\hline $\mathrm{J}$ - job stability & $\begin{array}{l}-17.63 \text { *** } \\
(1.69)\end{array}$ & $\begin{array}{l}-12.28^{* * *} \\
(1.61)\end{array}$ & $\begin{array}{l}10.63^{* * *} \\
(0.72)\end{array}$ & $\begin{array}{l}-7.00 * * * \\
(0.90)\end{array}$ \\
\hline E - employment & $\begin{array}{l}-10.82 \text { *** } \\
(1.80)\end{array}$ & $\begin{array}{l}-11.911^{* * *} \\
(2.21)\end{array}$ & $\begin{array}{l}12.17^{\star * *} \\
(1.07)^{4}\end{array}$ & $\begin{array}{l}-7.37^{* * *} \\
(1.07)\end{array}$ \\
\hline $\mathrm{R}$ - regional & $\begin{array}{l}-0.67 * \\
(0.38)\end{array}$ & $\begin{array}{l}-0.19 \\
(0.24)\end{array}$ & $\begin{array}{l}-0.09 \\
(0.09)\end{array}$ & $\begin{array}{l}-0.05 \\
(0.09)\end{array}$ \\
\hline approximation error & $\begin{array}{l}-1.85 \\
(5.17)\end{array}$ & $\begin{array}{l}-0.02 \\
(5.23)\end{array}$ & $\begin{array}{l}-4.03 \text { * } \\
(2.28)\end{array}$ & $\begin{array}{l}-1.77 \\
(1.96)\end{array}$ \\
\hline reweighting error & $\begin{array}{r}0.37 \\
(1.62)\end{array}$ & $\begin{array}{l}7.05^{* * *} \\
(1.92)\end{array}$ & $\begin{array}{l}1.82 \text { ** } \\
(0.76)\end{array}$ & $\begin{array}{l}-1.16 \\
(0.94)\end{array}$ \\
\hline
\end{tabular}

Notes: See Table I. Number of observations: East Germany 1993-1997: 60,676; East Germany 1998-2002: 51,892; East Germany 2004-2008: 46,341; West Germany 1993-1997: 189,533; West Germany 1998-2002: 187,681; West Germany 2004-2008: 184,846.

Source: SIAB (1975-2008). 
TABLE III

DECOMPOSITION RESUlTS - ROBUSTNESS TEST 1: DROP BERLIN

\begin{tabular}{lccc}
\hline & & & \\
period 1 & $1993-1997$ & $1998-2002$ & $1993-1997$ \\
period 0 & $1998-2002$ & $2004-2008$ & $2004-2008$ \\
& & East (w.o. Berlin) \\
& &
\end{tabular}

\begin{tabular}{lc} 
A. Description & \\
period 1 & 380.32 \\
& $(3.31)$ \\
period 0 & $225.13 \star \star \star$ \\
& $(2.59)$ \\
change & $-155.19 * \star$ \\
& $(4.18)$ \\
\hline
\end{tabular}

B. Aggregate Decomposition

\begin{tabular}{lccc} 
composition & $-38.80^{\star \star *}$ & $-30.17^{\star \star \star}$ & -79.39 \\
structure & $(2.98)$ & $(3.56)$ & $(7.28)$ \\
& $-113.08^{\star \star *}$ & $-20.77^{\star \star \star}$ & $-137.63^{\star \star *}$ \\
\hline
\end{tabular}

C. Detailed Decomposition of Composition Effect

\begin{tabular}{|c|c|c|c|}
\hline $\mathrm{Z}$ - individual & $\begin{array}{l}-6.88^{\star \star \star} \\
(1.13)\end{array}$ & $\begin{array}{l}-6.76^{\star \star \star} \\
(1.88)\end{array}$ & $\begin{array}{l}-9.55 * \star \\
(4.46)\end{array}$ \\
\hline $\mathrm{J}$ - job stability & $\begin{array}{l}-19.23 * \star \star \\
(1.66)\end{array}$ & $\begin{array}{c}-11.99 \\
(1.88)\end{array}$ & $\begin{array}{l}-34.37^{\star \star \star \star} \\
(3.03)\end{array}$ \\
\hline E - employment & $\begin{array}{l}-12.71 \\
(1.75)\end{array}$ & $\begin{array}{l}-11.43 \\
(2.02)\end{array}$ & $\begin{array}{l}-35.57 \text { *** } \\
(4.32)\end{array}$ \\
\hline $\mathrm{R}$ - regional & $\begin{array}{r}0.02 \\
(0.18)\end{array}$ & $\begin{array}{r}0.01 \\
(0.11)\end{array}$ & $\begin{array}{r}0.08 \\
(0.16)\end{array}$ \\
\hline approximation error & $\begin{array}{l}-2.34 \\
(6.16)\end{array}$ & $\begin{array}{l}-0.21 \\
(5.45)\end{array}$ & $\begin{array}{r}-4.54 \\
(11.38)\end{array}$ \\
\hline reweighting error & $\begin{array}{l}-0.96 \\
(1.73)\end{array}$ & $\begin{array}{l}6.96 \\
(1.85)\end{array}$ & $\begin{array}{l}22.19 \\
(7.12)\end{array}$ \\
\hline
\end{tabular}

Notes: See Table I. Observations employed in Berlin in period $t$ are omitted from the sample. Number of observations: 1993-1997: 51,332; 1998-2002: 43,803; 2004-2008: 39,100.

Source: SIAB (1975-2008). 


\begin{tabular}{llll}
\hline & & & \\
period 1 & $1993-1997$ & $1998-2002$ & $1993-1997$ \\
period 0 & $1998-2002$ & $2004-2008$ & $2004-2008$ \\
& & East Germany \\
& & \\
\hline \hline
\end{tabular}

A. Description

\begin{tabular}{|c|c|c|c|}
\hline period 1 & $\begin{array}{l}340.12 \text { *** } \\
(2.85)\end{array}$ & $\begin{array}{l}243.52 \text { *** } \\
(2.98)\end{array}$ & $\begin{array}{c}340.12 \text { *** } \\
(2.32)\end{array}$ \\
\hline period 0 & $\begin{array}{c}243.52 \text { *** } \\
(2.98)\end{array}$ & $\begin{array}{l}195.01 \\
(2.79)\end{array}$ & $\begin{array}{c}195.01 \\
(2.74)\end{array}$ \\
\hline change & $\begin{array}{l}-96.60 * * * \\
(4.28)\end{array}$ & $\begin{array}{l}-48.51 \\
(4.23)\end{array}$ & $\begin{array}{c}-145.11 \\
(3.70)\end{array}$ \\
\hline
\end{tabular}

B. Aggregate Decomposition

\begin{tabular}{llll} 
composition & $-25.26^{* * *}$ & $-38.38^{* * *}$ & -68.92 \\
& $(2.76)$ & $(2.98)$ & $(4.87)$ \\
structure & $-71.28^{* * *}$ & $-13.48^{* * *}$ & -82.94 \\
& $(4.35)$ & $(4.31)$ & $(5.61)$ \\
\hline
\end{tabular}

C. Detailed Decomposition of Composition Effect

\begin{tabular}{|c|c|c|c|}
\hline Z - individual & $\begin{array}{l}-7.07^{\star \star \star} \\
(1.51)\end{array}$ & $\begin{array}{l}-21.35 \text { *** } \\
(2.04)\end{array}$ & $\begin{array}{l}-30.43^{\star \star *} \\
(2.35)\end{array}$ \\
\hline $\mathrm{J}$ - job stability & $\begin{array}{l}-13.18 \\
(1.34)\end{array}$ & $\begin{array}{l}-11.37 \\
(1.51)\end{array}$ & $\begin{array}{l}-22.37 \text { *** } \\
(2.34)\end{array}$ \\
\hline E - employment & $\begin{array}{l}-4.28 \\
(1.47)\end{array}$ & $\begin{array}{l}-5.66 \\
(1.90)\end{array}$ & $\begin{array}{l}-14.64 \\
(3.09)\end{array}$ \\
\hline $\mathrm{R}$ - regional & $\begin{array}{l}-0.73 \text { ** } \\
(0.30)\end{array}$ & $\begin{array}{r}0.00 \\
(0.27)\end{array}$ & $\begin{array}{l}-1.48 \text { *** } \\
(0.43)\end{array}$ \\
\hline approximation error & $\begin{array}{c}-1.38 \\
(5.29)\end{array}$ & $\begin{array}{l}-0.19 \\
(5.23)\end{array}$ & $\begin{array}{l}-3.30 \\
(7.02)\end{array}$ \\
\hline reweighting error & $\begin{array}{r}1.32 \\
(1.53)\end{array}$ & $\begin{array}{r}3.53 \\
(2.04)\end{array}$ & $\begin{array}{l}10.04 \text { *** } \\
(3.42)\end{array}$ \\
\hline
\end{tabular}

Notes: See Table I. The ranks were calculated for the pooled East and West German wage distribution. The decomposition is performed for those observations, who are employed in East Germany in the base period $(t)$ independent of where they are employed in period $t+4$. Number of observations 1993-1997: 65,292; 1998-2002: 54,999; 2004-2008: 49,038.

Source: SIAB (1975-2008). 


\section{APPENDIX}

TABLE A. 1

Number of ANNUAL OBSERVATIONS IN Full SAMPLE AND In MOBILITy ANALySES

\begin{tabular}{|c|c|c|c|c|c|c|}
\hline \multirow[b]{2}{*}{ Year } & \multicolumn{3}{|c|}{ West Germany } & \multicolumn{3}{|c|}{ East Germany } \\
\hline & $\mathbf{t}$ & $\begin{array}{c}\text { t \& t+4 } \\
\text { abs. }\end{array}$ & $\begin{array}{c}t \& t+4 \\
\text { in } \%\end{array}$ & $\mathbf{t}$ & $\begin{array}{c}\text { t \& t+4 } \\
\text { abs. }\end{array}$ & $\begin{array}{c}t \& t+4 \\
\text { in } \%\end{array}$ \\
\hline 1975 & 229,173 & 171,123 & 0.75 & & & \\
\hline 1976 & 229,826 & 172,463 & 0.75 & & & \\
\hline 1977 & 233,020 & 174,423 & 0.75 & & & \\
\hline 1978 & 233,252 & 171,417 & 0.73 & & & \\
\hline 1979 & 240,586 & 172,122 & 0.72 & & & \\
\hline 1980 & 242,998 & 171,930 & 0.71 & & & \\
\hline 1981 & 243,737 & 170,963 & 0.70 & & & \\
\hline 1982 & 240,919 & 172,945 & 0.72 & & & \\
\hline 1983 & 236,286 & 171,147 & 0.72 & & & \\
\hline 1984 & 237,829 & 173,507 & 0.73 & & & \\
\hline 1985 & 236,028 & 172,254 & 0.73 & & & \\
\hline 1986 & 242,790 & 177,151 & 0.73 & & & \\
\hline 1987 & 245,336 & 178,227 & 0.73 & & & \\
\hline 1988 & 249,548 & 180,022 & 0.72 & & & \\
\hline 1989 & 256,878 & 182,117 & 0.71 & & & \\
\hline 1990 & 269,878 & 184,992 & 0.69 & & & \\
\hline 1991 & 280,101 & 189,907 & 0.68 & & & \\
\hline 1992 & 283,999 & 191,013 & 0.67 & 98,967 & 64,419 & 0.65 \\
\hline 1993 & 281,241 & 189,906 & 0.68 & 94,949 & 62,431 & 0.66 \\
\hline 1994 & 276,411 & 189,413 & 0.69 & 93,100 & 60,941 & 0.65 \\
\hline 1995 & 275,693 & 191,082 & 0.69 & 92,450 & 60,548 & 0.65 \\
\hline 1996 & 271,929 & 191,855 & 0.71 & 89,918 & 58,687 & 0.65 \\
\hline 1997 & 268,761 & 189,956 & 0.71 & 85,320 & 55,406 & 0.65 \\
\hline 1998 & 268,893 & 188,040 & 0.70 & 82,641 & 53,105 & 0.64 \\
\hline 1999 & 270,074 & 187,241 & 0.69 & 81,224 & 52,033 & 0.64 \\
\hline 2000 & 273,463 & 188,047 & 0.69 & 78,512 & 50,028 & 0.64 \\
\hline 2001 & 272,230 & 187,394 & 0.69 & 75,368 & 47,961 & 0.64 \\
\hline 2002 & 265,904 & 186,372 & 0.70 & 71,997 & 46,884 & 0.65 \\
\hline 2003 & 259,578 & 186,538 & 0.72 & 69,426 & 46,934 & 0.68 \\
\hline 2004 & 253,159 & 184,855 & 0.73 & 66,771 & 46,343 & 0.69 \\
\hline
\end{tabular}

Notes: The columns entitled " $t$ " provide the number of sample observations observed in the base period (calendar year provided in "Year" column). The columns entitled " $t \& t+4$ " provide the number of observations ("abs") with wage observations in periods $t$ and $t+4$ as well as their share ("in \%") in the number of observations in the base period.

Source: SIAB (1975-2008). 
FigURE A.1

Changes in Real Wages

A1.1 West Germany - Base Year 1975

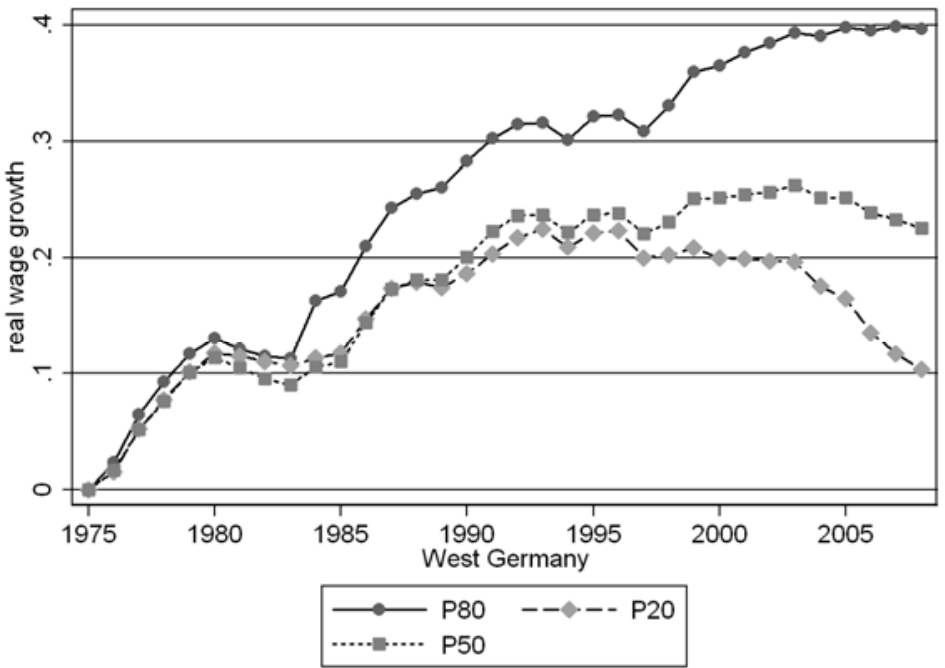

A1.2 West and East Germany - Base Year 1992
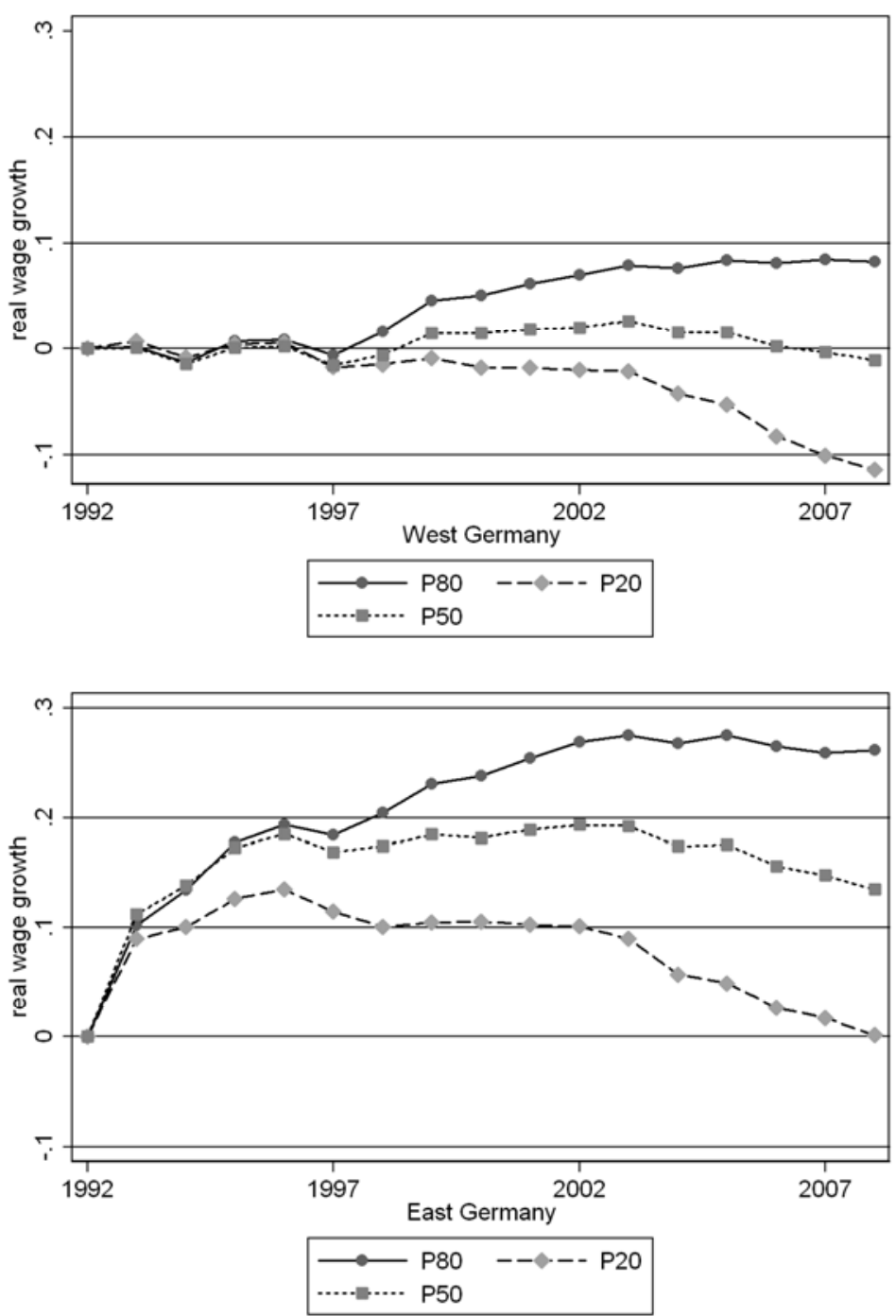

Source: SIAB (1975-2008). 
FIGURE A.2

Development of Mean Absolute Change in Real Wages
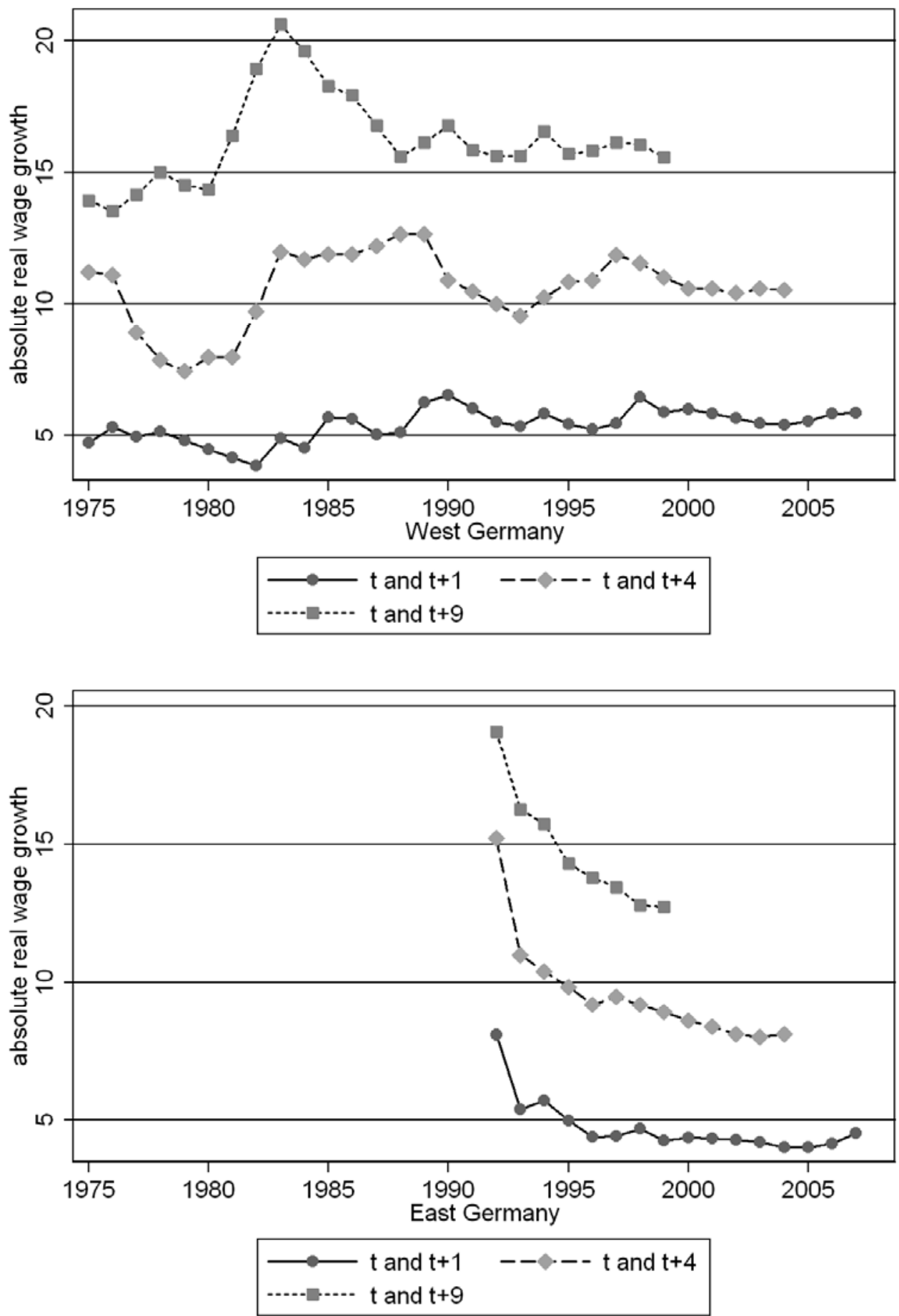

Notes: Only developments for the uncensored part of the daily wage distribution are described.

Source: SIAB (1975-2008). 
FIGURE A.3

Development of Mean Relative Change in Real Wages
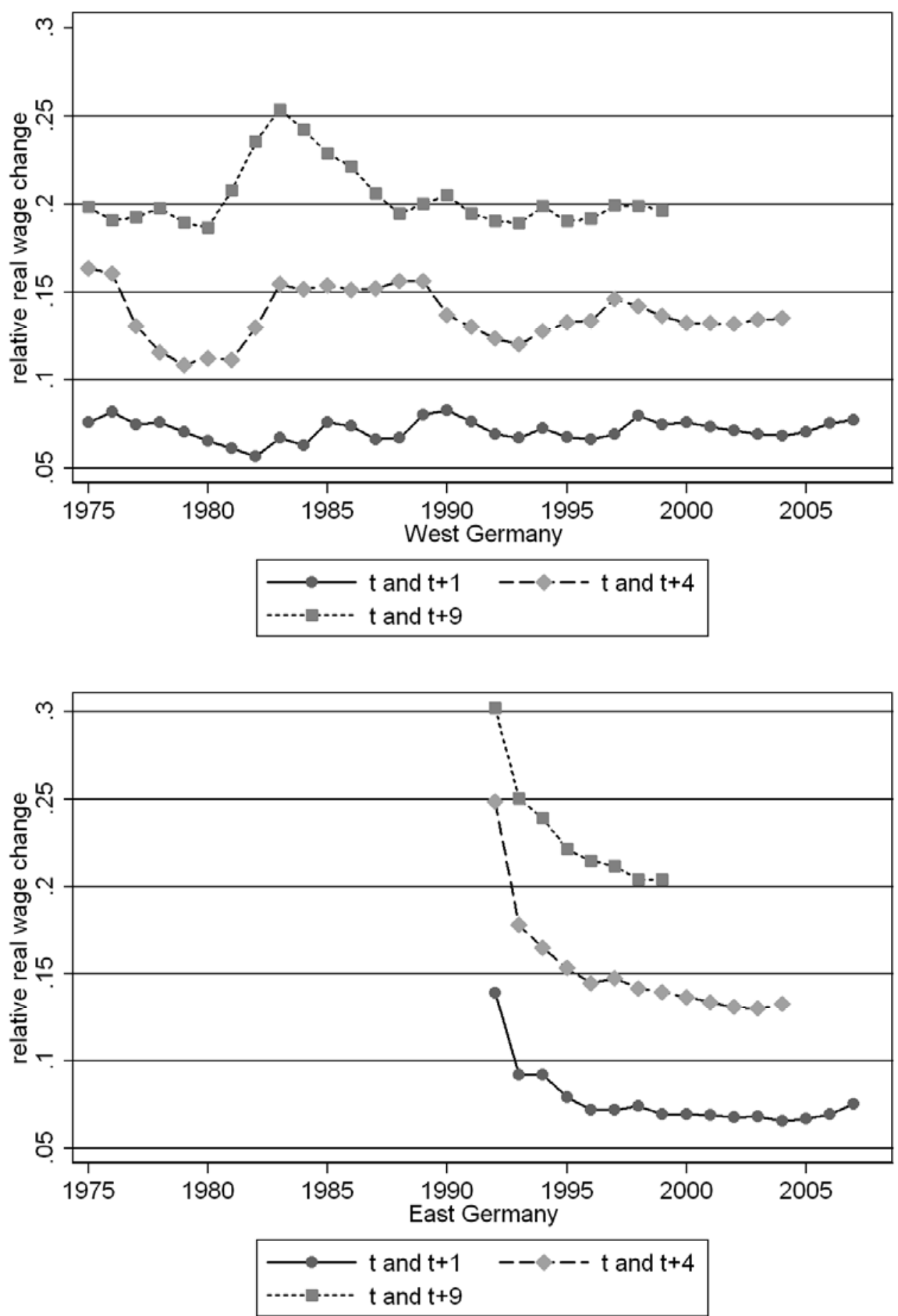

Notes: Only developments for the uncensored part of the daily wage distribution are described.

Source: SIAB (1975-2008). 
FIGURE A.4

Age-Specific Wage Mobility by Year and Region
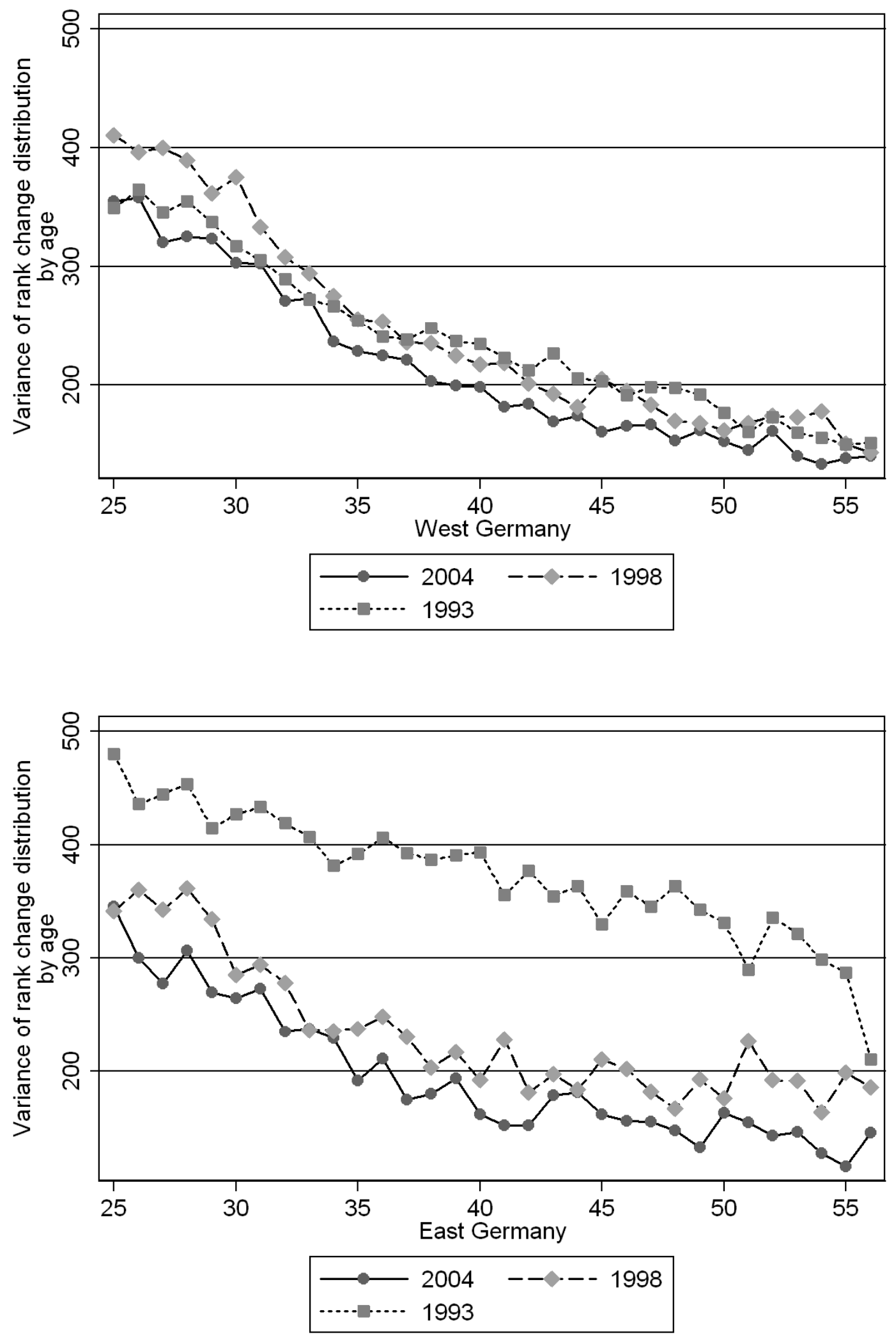

Notes: The graphs are based on noncensored observations and regionally defined wage ranks. Source: SIAB (1975-2008). 
FIGURE A.5

Wage Mobility by Start Position Quintile and Region over Time
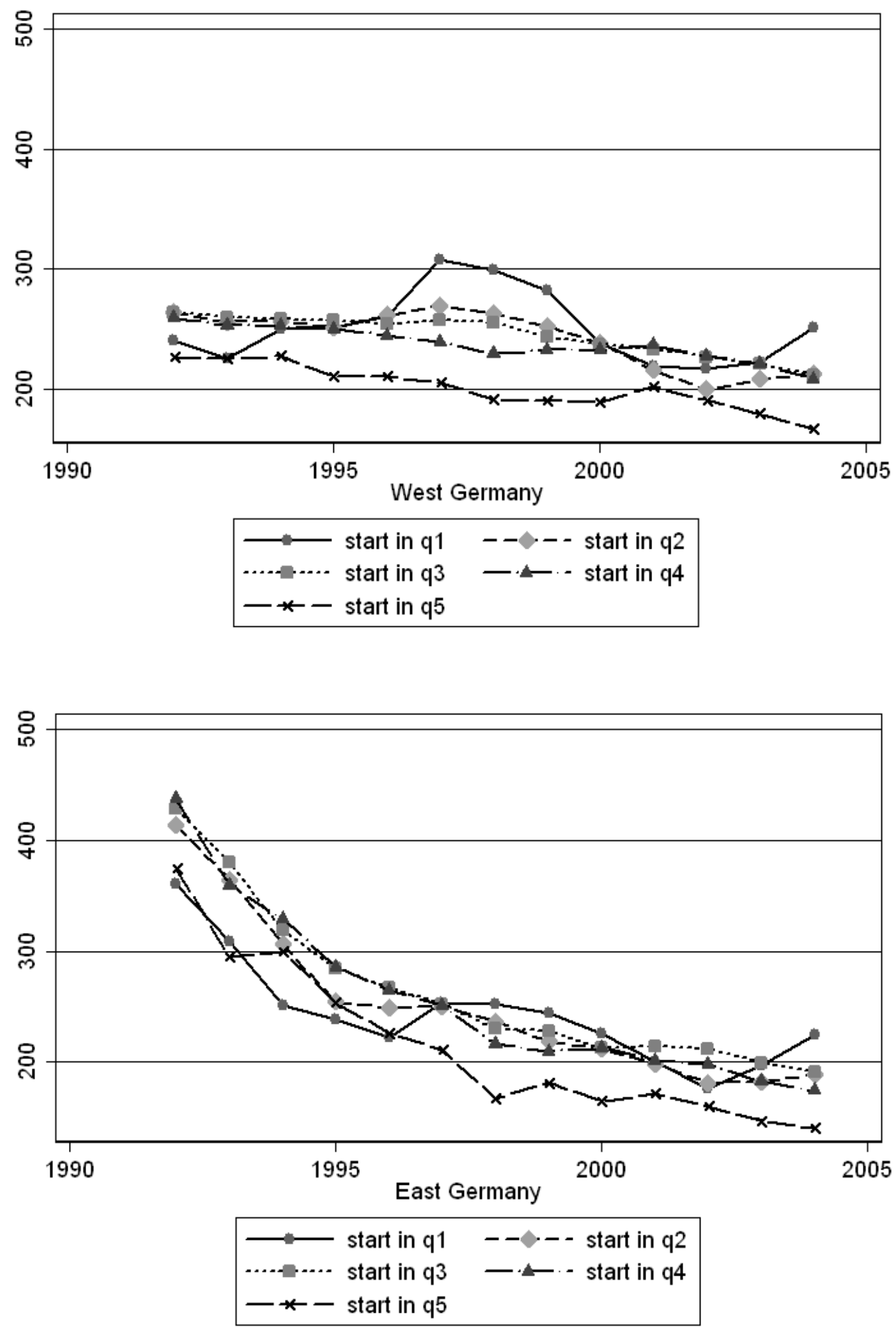

Notes: The graphs are based on noncensored observations and regionally defined wage ranks. The y-axis reflects the variance of the rank change distribution. q1-q5 represent the lowest to highest quintile in the wage distribution in period $t$.

Source: SIAB (1975-2008). 
FIGURE A.6

Variances of Rank Change Distribution Based on National Ranks and Redefined Samples

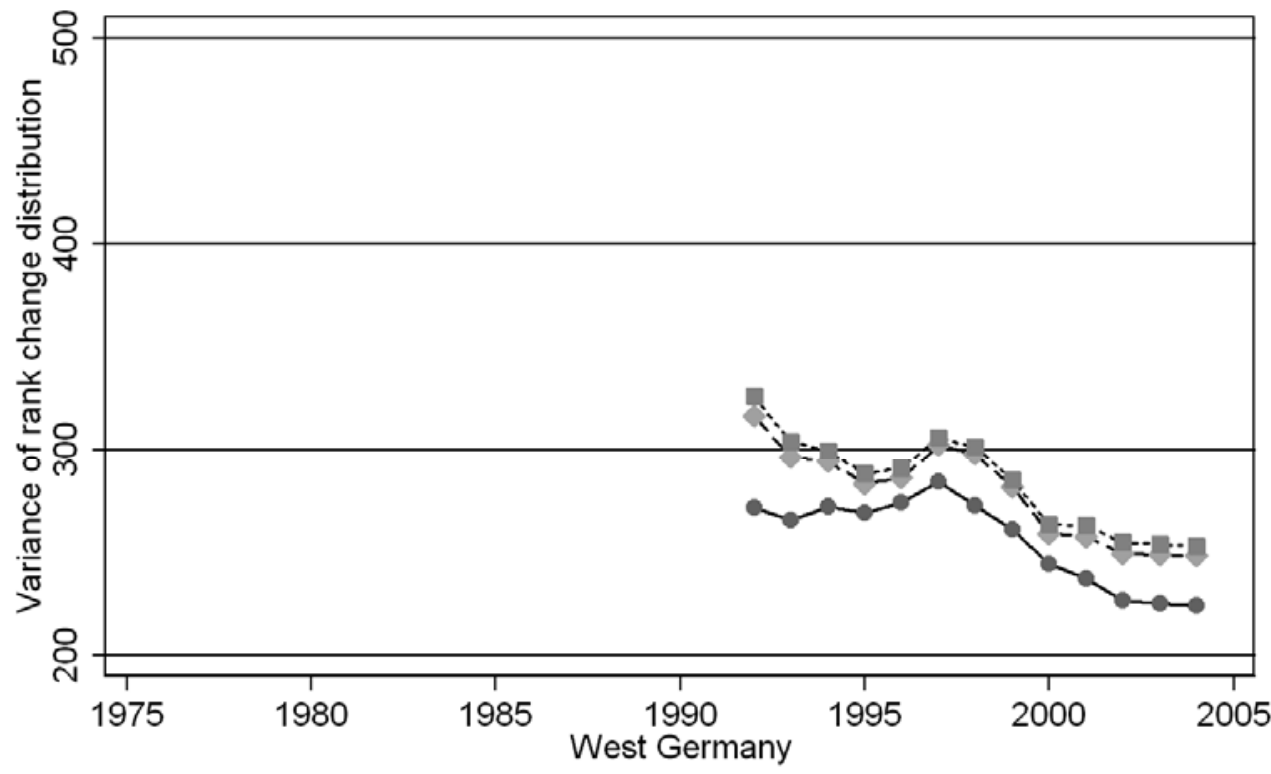

$\longrightarrow$ regional ranks, no migr. $\quad--\bullet--$ national ranks, no migr. national ranks incl. migr.

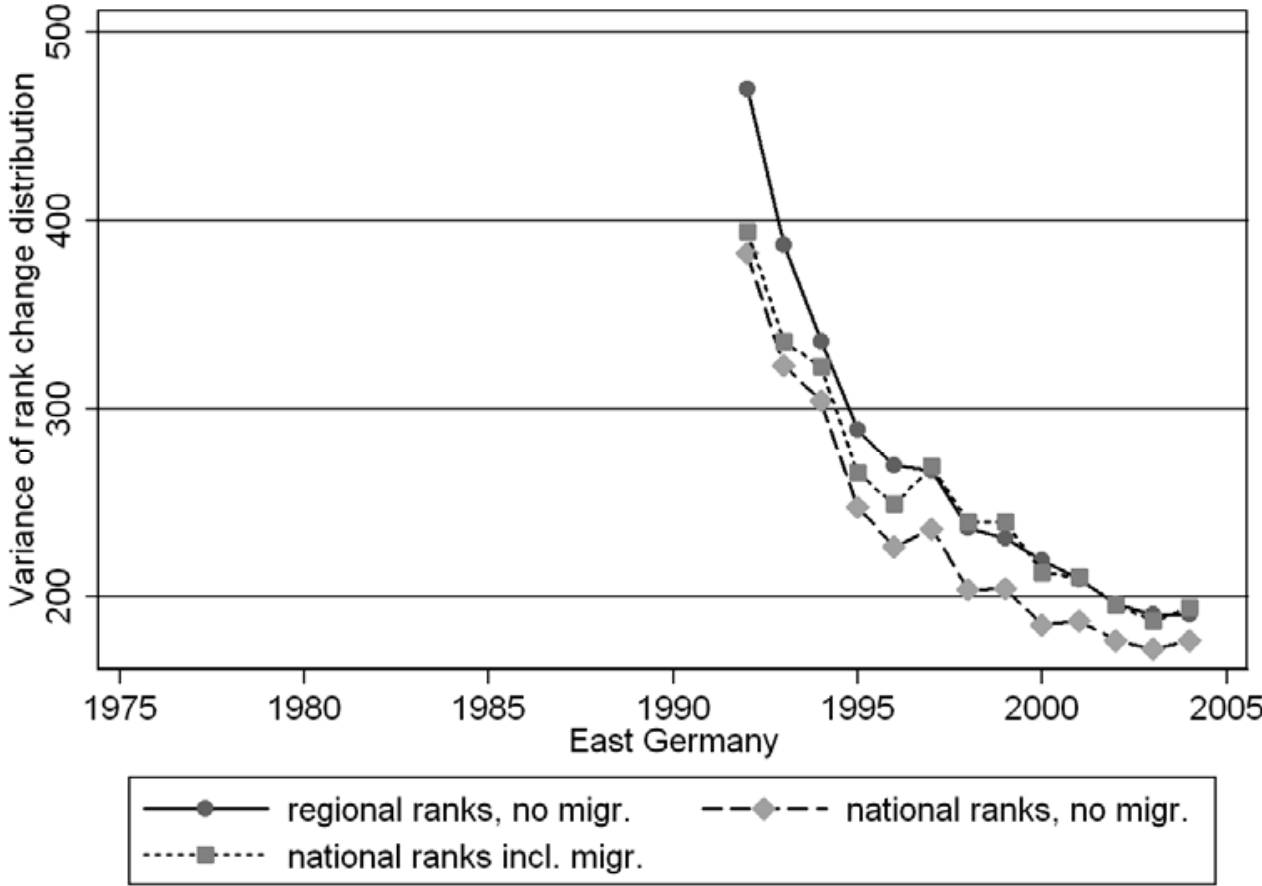

Notes: The series "regional ranks, no mig." describe the aggregate mobility patterns analyzed in Tables I and II. The series "national ranks, no migr." uses the same samples but assigns wage ranks based on the national instead of the regional wage distribution. The series "national ranks, incl. migr." considers those individuals who in the based period $t$ are observed in the assigned region independent of whether they migrate by period $t+4$. It uses national rank assignments.

Source: SIAB (1975-2008). 


\section{Electronic Appendix - not intended for publication}

Table of contents

Data Appendix

Supplementary Material:

Figure EA.1 Development of Shorrocks Indices for Regional Subsamples with Censored and Uncensored Data from Survey Data (SOEP)

Table EA.1 Descriptive statistics and results of the reweighting step

Table EA.2 RIF regressions

Table EA.3 Decomposition results - robustness test: swapping $\mathrm{t}=0$ and $\mathrm{t}=1$

Table EA.4 p-values of tests of significant changes in RIF regression coefficients over time

Table EA.5 Decomposition results - robustness test: using national ranks 


\section{Data Appendix}

The SIAB data are drawn from the Integrated Employment Biographies (IEB 1975-2008) and provided by the Institute for Employment Research. We consider observations from Berlin as part of the East German sample after unification and omit them from the sample before. Our sample considers full-time employed workers. Full-time employment is coded if the person's contract runs over that number of weekly hours which is considered full-time in the employee's establishment. Depending on bilateral bargaining agreements this number may vary between 35 and 45 hours per week (see Dorner et al. 2010). As we inspect earnings of full-time workers over time it is important to note that their average annual hours worked hardly changed over the considered period in East and West Germany (see Wanger 2006). This data appendix describes the dependent variable in section 1 and explanatory variables in section 2. Tables EA.1.A and EA.1.B present descriptive statistics as of the three base years ( $t$ ) considered in the mobility analyses (1993, 1998, 2004).

Dependent Variable of the Decomposition Analyses

1.1

\section{Wage Measure}

Our data provide employment spells. We are interested in wages of full-time employment relationships, only. If several simultaneous full-time employment relationships are reported for a given person over the course of a calendar year we consider the wage of the main job. The main job is the one with the longest spell duration or, if several employment relationships have the same duration, the one with the highest daily wages. ${ }^{1}$ Since we are interested in wage mobility in the main job we do not consider information on secondary jobs. We use the daily wage observation for every individual that was full-time employed at least one day in a given year. The daily wage is measured in 2008 prices.

Wage observations are censored at the contribution limit of the mandatory retirement insurance. This upper threshold varies by year and by region (i.e., east and west). To ensure that we observe a constant share of the wage distribution in both regions over time we apply a

$1 \quad$ On average about 15 percent of the employees in our sample experienced more than one full-time employment spell over the course of the year. By considering the wage of a "main job" we differ from the procedure applied by Dustmann et al. (2009), who use the average wage of all full-time employment relationships in a given calendar year. 
consistent top-coding approach (Burkhauser et al. 2009): we censor the regional wage distribution at the highest percentile that remains uncensored in all years. For West Germany this is the 85th percentile and for East Germany this is the 90th percentile.

The data contain two structural breaks. (a) Since 1984 one-time payments such as bonuses are added to earnings. While various authors who study wages or inequality with our data correct for this break using a method developed by Fitzenberger (1999) we omit this adjustment for two reasons: first, it is unlikely that the addition of bonuses to the upper tail of the wage distribution affects rank positions and mobility, and second the correction method does not provide imputations for individuals observed only prior to 1984. As our main analysis focuses on the period after 1992 it is not affected by this structural break. (b) Since 1999 information on minor employment is registered. However, since we condition on fulltime employment this should not affect our results.

\section{$1.2 \quad$ Wage Ranks}

Our key variable is the change in the individual rank in the wage distribution between two years, $t$ and $t+k$. To obtain this change, we first define the rank in an annual wage distribution. For a given year $t$, we divide the uncensored part of the wage distribution (up to the 85th percentile in West Germany and up to the 90th percentile in East Germany) into 100 percentiles and assign each uncensored wage observation one of these 100 rank positions for this year. We repeat the same procedure for year $t+k$ to calculate the individual wage rank in $t+k$. The difference between these two ranks is our measure of individual wage mobility. The variance of the distribution of these individual rank changes is our main aggregate measure of wage mobility which we interpret as a characteristic of the regional labor market.

\section{Explanatory Variables of the Decomposition Analyses}

\section{1}

\section{Individual Characteristics $Z$}

Education: we use three categories to describe individual education. We classify individuals to be low educated if they have no degree at all or if they finished school (without university entrance certificate) but did not complete vocational training. An individual is medium educated if the person finished school and vocational training or if the person holds a 
university entrance degree but does not hold a university degree. Individuals holding a university degree are classified as high educated (for a similar classification see Dustmann et al. (2009)). As the data show many missing values for the education variable, we imputed education according to the procedure IP 1 suggested by Fitzenberger et. al (2006).

Age: we use six age categories: (1) 25-30, (2) 31-35, (3) 36-40, (4) 41-45, (5) 46-50, and (6) $>50$ years. As we analyze a five year period and age is measured in the start year $t$, the highest age in the last category is 56. Otherwise, an individual would exceed age 60 in period $t+4$, which violates our age restriction.

Starting position: we control for the individual's rank position in the wage distribution in the start year. The variable considers ten categories according to the 10 deciles of the uncensored part of the wage distribution.

Citizenship: indicator variable $(=1)$ if person is not of German citizenship.

Sex: indicator variable $(=1)$ if person is female.

Migrates west: indicator variable $(=1)$ if person migrates to West Germany in the future. This information is only calculated for the East German sample.

Firm change: indicator variable $(=1)$ if individual changes employers between $t$ and $t+4$. Unemployment: we control for individuals' unemployment experience in the period between $t$ and $t+4$. We consider an individual as unemployed if the person is observed to receive unemployment benefits (this includes short term as well as long term unemployment). We consider four categories: (1) no unemployment experience, (2) up to half a year of unemployment experience, (3) more than half a year but less than 1 year of unemployment experience, (4) more than 1 year of unemployment experience.

Tenure: tenure is measured in four categories: (1) less than half a year, (2) between half a year and 1 year, (3) between 1 and 2 years, (4) more than 2 years.

\subsection{Employer and Employment Characteristics (E)}

Firm size: we include six firm size categories: (1) up to 10 employees, (2) between 10 and 25, (3) 25 to 50, (4) 51 to 100, (5) 101 to 1000, (6) more than 1000 employees. 
Industry: we control for 9 industries: (1) agriculture, (2) energy, water supply, mining, (3) manufacturing, (4) construction, (5) retail, (6) transport and telecommunication, (7) banking and insurance, (8) services, (9) administration, non-profit organizations, private households.

Decreasing workforce: indicator variable $(=1)$ if an individual's employer reduces the number of employees between $t$ and $t+4$.

Occupation group: we control for 11 occupation groups (according to Blossfeld 1985): (1) simple manual occupation, (2) qualified manual occupations, (3) technicians and engineers, (4) simple services, (5) qualified services, (6) semi professions, (7) professions, (8) simple sales and administration occupations, (9) qualified sales and administration occupations, (10) manager, (11) miscellaneous.

Industry change: indicator variable $(=1)$ if individual changes industry between $t$ and $t+4$. Occupation change: indicator variable $(=1)$ if individual changes occupational groups between $t$ and $t+4$.

2.4

\section{Regional Information $(R)$}

State indicators: indicator variables for the federal state (Bundesland) of the individual workplace.

\section{REFERENCES}

Blossfeld, Hans-Peter, 1985, Bildungsexpansion und Berufschancen. Empirische Analysen zur Lage der Berufsanfänger in der Bundesrepublik, Campus, Frankfurt/New York.

Burkhauser, Richard V., Shuaizhang Feng, and Stephen P. Jenkins, 2009, Using the P90/P10 Index to Measure U.S. Inequality Trends with Current Population Survey Data: A View from Inside the Census Bureau Vaults, Review of Income and Wealth 55(1), 166-185.

Dorner, Matthias, Jörg Heining, Peter Jacobebbinghaus, and Stefan Seth, 2010, Stichprobe der Integrierten Arbeitsmarktbiografien (SIAB), 1975-2008, FDZ-Datenreport 01/2010, IAB, Nürnberg.

Fitzenberger, Bernd, 1999, Wages and Employment Across Skill Groups: An Analysis for West Germany, ZEW Economic Studies 6, Physica Verlag, Heidelberg.

Fitzenberger, Bernd, A. Osikominu, and R. Völter, 2006, Imputation Rules to Improve the Education Variable in the IAB Employment Subsample, Journal of the Applied Social Sciences 126(3), 405-436.

Wagner, Gert G., Joachim R. Frick, and Jürgen Schupp, 2007, The German Socio-Economic Panel Study (SOEP) - Scope, Evolution, and Enhancements, Journal of Applied Social Science Studies (Schmollers Jahrbuch), 127(1), 139-169. 
Figure EA.1 Development of Shorrocks Indices for Regional Subsamples with Censored and Uncensored Data from Survey Data (SOEP)
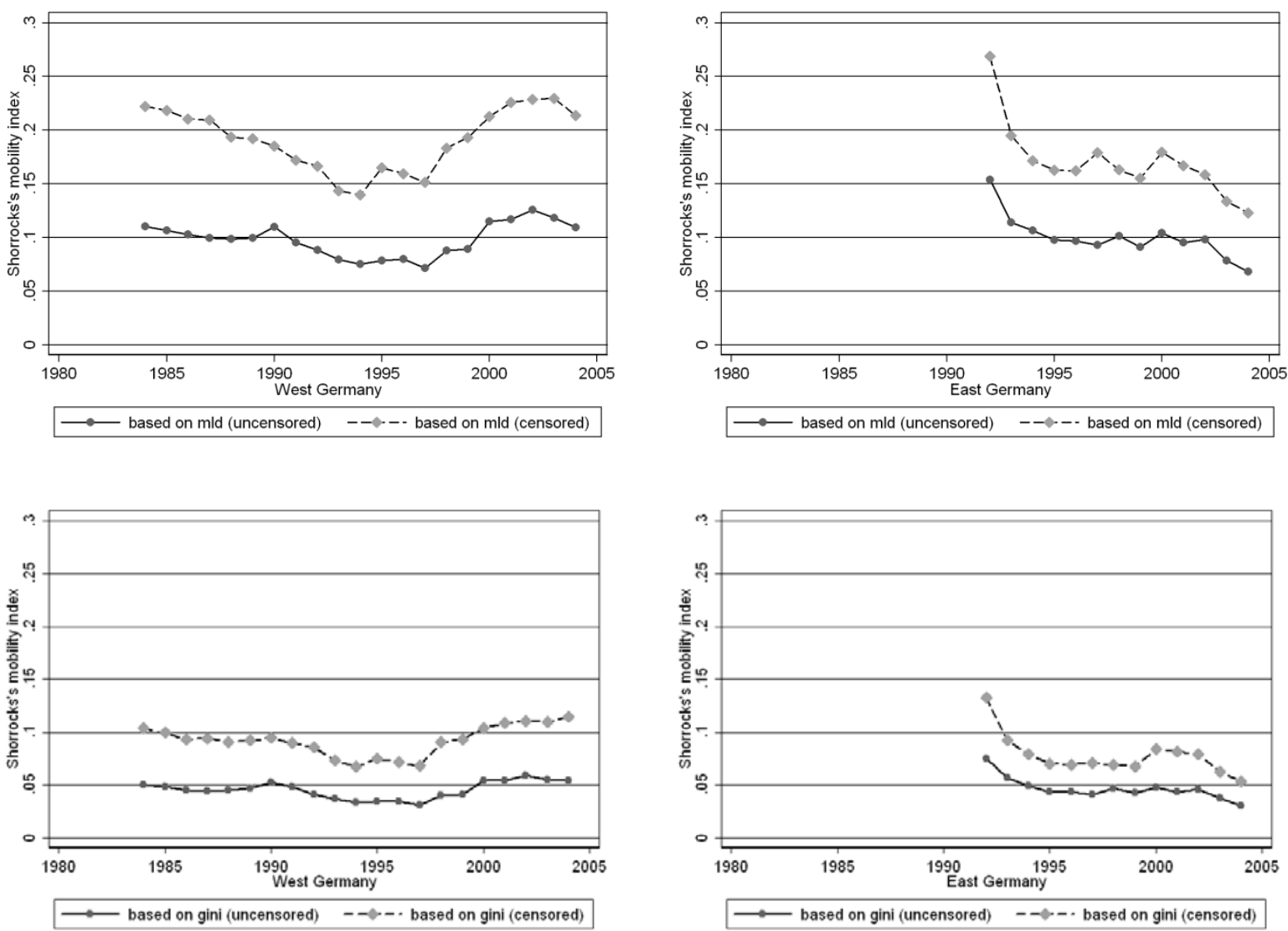

Notes: Values are based on the uncensored wage distribution in the German Socio-Economic Panel (Wagner et al. 2007). The sample is comparable to the sample from the administrative data: included are full-time workers excluding self-employed workers and civil servants; individuals are between 25 and 60 years of age; region is assigned by place of residence; all values are calculated for an accounting period of five years (i.e. years $t$ to $t+4$ ). Indicators labeled "mld" present the Shorrocks index when using a mean log deviation inequality measure. Indicators labeled "gini" are based on the Gini coefficient as an inequality measure; the results are weighted.

Source: SOEPv27 (1984-2010). 
Table EA.1.A Descriptive Statistics and Results of the Reweighting Step (East Germany): Mean Values of Observed Characteristics

\begin{tabular}{|c|c|c|c|c|c|c|c|c|c|c|}
\hline & & base 1993 & $\begin{array}{c}\text { base } 2004 \\
\text { reweighted } \\
\text { to } 1993 \\
\text { B }\end{array}$ & $\begin{array}{c}\text { base } 1998 \\
\text { reweighted } \\
\text { to } 1993 \\
\text { C }\end{array}$ & base 1998 & $\begin{array}{c}\text { base } 2004 \\
\text { reweighted } \\
\text { to } 1998 \\
\mathbf{E}\end{array}$ & base 2004 & diff. & diff. & diff. \\
\hline \multicolumn{11}{|l|}{$\overline{\mathrm{Z} \text { - Individual }}$} \\
\hline \multirow[t]{6}{*}{ age } & $25-30$ & 0.21 & 0.22 & 0.21 & 0.16 & 0.16 & 0.12 & -0.01 & 0.00 & 0.00 \\
\hline & $31-35$ & 0.20 & 0.19 & 0.20 & 0.19 & 0.19 & 0.14 & 0.01 & 0.00 & 0.00 \\
\hline & $36-40$ & 0.19 & 0.18 & 0.18 & 0.20 & 0.20 & 0.19 & 0.00 & 0.00 & 0.00 \\
\hline & $41-45$ & 0.16 & 0.16 & 0.16 & 0.18 & 0.18 & 0.21 & 0.00 & 0.00 & 0.00 \\
\hline & $46-50$ & 0.12 & 0.12 & 0.12 & 0.15 & 0.16 & 0.18 & 0.00 & 0.00 & 0.00 \\
\hline & $>50$ & 0.13 & 0.13 & 0.13 & 0.11 & 0.11 & 0.16 & 0.00 & 0.00 & 0.00 \\
\hline \multirow[t]{10}{*}{ start position } & $1-10$ & 0.08 & 0.09 & 0.08 & 0.08 & 0.08 & 0.07 & -0.01 & 0.00 & 0.00 \\
\hline & $11-20$ & 0.09 & 0.09 & 0.09 & 0.08 & 0.08 & 0.09 & 0.00 & 0.00 & 0.00 \\
\hline & $21-30$ & 0.10 & 0.09 & 0.09 & 0.10 & 0.09 & 0.10 & 0.00 & 0.00 & 0.00 \\
\hline & $31-40$ & 0.10 & 0.10 & 0.10 & 0.10 & 0.10 & 0.11 & 0.01 & 0.00 & 0.00 \\
\hline & $41-50$ & 0.11 & 0.10 & 0.11 & 0.11 & 0.11 & 0.11 & 0.01 & 0.00 & 0.00 \\
\hline & $51-60$ & 0.11 & 0.11 & 0.11 & 0.11 & 0.11 & 0.11 & 0.00 & 0.00 & 0.00 \\
\hline & $61-70$ & 0.11 & 0.11 & 0.11 & 0.11 & 0.12 & 0.11 & 0.00 & 0.00 & 0.00 \\
\hline & $71-80$ & 0.11 & 0.11 & 0.11 & 0.11 & 0.11 & 0.11 & 0.00 & 0.00 & 0.00 \\
\hline & $81-90$ & 0.11 & 0.11 & 0.11 & 0.11 & 0.11 & 0.11 & 0.00 & 0.00 & 0.00 \\
\hline & $91-100$ & 0.08 & 0.09 & 0.09 & 0.09 & 0.09 & 0.09 & 0.00 & 0.00 & 0.00 \\
\hline \multirow[t]{3}{*}{ education } & low & 0.06 & 0.07 & 0.06 & 0.03 & 0.04 & 0.03 & -0.01 & 0.00 & 0.00 \\
\hline & medium & 0.86 & 0.85 & 0.86 & 0.87 & 0.87 & 0.87 & 0.01 & 0.00 & 0.00 \\
\hline & high & 0.08 & 0.09 & 0.08 & 0.09 & 0.09 & 0.10 & 0.00 & 0.00 & 0.00 \\
\hline citizenship & non-german & 0.01 & 0.02 & 0.02 & 0.01 & 0.01 & 0.01 & 0.00 & 0.00 & 0.00 \\
\hline $\operatorname{sex}$ & female & 0.42 & 0.43 & 0.42 & 0.42 & 0.42 & 0.41 & -0.01 & 0.00 & 0.00 \\
\hline migrates west & yes $=1$ & 0.08 & 0.10 & 0.08 & 0.05 & 0.05 & 0.01 & -0.01 & 0.00 & 0.00 \\
\hline \multicolumn{11}{|l|}{ J - Job Stability } \\
\hline \multirow[t]{4}{*}{ unemployment } & not unempl. & 0.65 & 0.65 & 0.65 & 0.69 & 0.69 & 0.69 & 0.00 & 0.00 & 0.00 \\
\hline & 0-0.5 year & 0.15 & 0.15 & 0.15 & 0.12 & 0.12 & 0.10 & 0.00 & 0.00 & 0.00 \\
\hline & $0.5-1$ year & 0.08 & 0.08 & 0.08 & 0.07 & 0.08 & 0.08 & 0.00 & 0.00 & 0.00 \\
\hline & $>1$ year & 0.12 & 0.12 & 0.12 & 0.12 & 0.12 & 0.13 & 0.00 & 0.00 & 0.00 \\
\hline \multirow[t]{4}{*}{ tenure } & $<0.5$ year & 0.07 & 0.07 & 0.07 & 0.07 & 0.08 & 0.07 & 0.00 & 0.00 & 0.00 \\
\hline & $0.5-1$ year & 0.18 & 0.20 & 0.19 & 0.16 & 0.16 & 0.10 & -0.01 & -0.01 & 0.00 \\
\hline & 1-2 years & 0.22 & 0.21 & 0.22 & 0.14 & 0.14 & 0.14 & 0.01 & 0.00 & 0.00 \\
\hline & $>2$ years & 0.53 & 0.52 & 0.53 & 0.63 & 0.63 & 0.70 & 0.01 & 0.00 & 0.00 \\
\hline
\end{tabular}




\begin{tabular}{|c|c|c|c|c|c|c|c|c|c|}
\hline \multicolumn{10}{|l|}{ E - Employer and Employment } \\
\hline firm size $1-10$ & 0.17 & 0.18 & 0.18 & 0.21 & 0.22 & 0.20 & -0.01 & -0.01 & 0.00 \\
\hline $11-25$ & 0.13 & 0.13 & 0.13 & 0.15 & 0.15 & 0.15 & 0.00 & 0.00 & 0.00 \\
\hline $26-50$ & 0.11 & 0.11 & 0.11 & 0.13 & 0.13 & 0.13 & 0.00 & 0.00 & 0.00 \\
\hline 51-100 & 0.12 & 0.12 & 0.12 & 0.13 & 0.13 & 0.14 & 0.00 & 0.00 & 0.00 \\
\hline $101-1000$ & 0.33 & 0.33 & 0.33 & 0.29 & 0.29 & 0.30 & 0.00 & 0.01 & 0.00 \\
\hline$>1000$ & 0.14 & 0.14 & 0.14 & 0.09 & 0.09 & 0.07 & 0.01 & 0.00 & 0.00 \\
\hline agriculture & 0.01 & 0.01 & 0.01 & 0.01 & 0.01 & 0.03 & 0.00 & 0.00 & 0.00 \\
\hline energy, water, mining & 0.03 & 0.02 & 0.02 & 0.02 & 0.02 & 0.01 & 0.01 & 0.00 & 0.00 \\
\hline manufacturing & 0.23 & 0.22 & 0.23 & 0.24 & 0.23 & 0.22 & 0.01 & 0.00 & 0.00 \\
\hline construction & 0.15 & 0.16 & 0.16 & 0.14 & 0.15 & 0.12 & -0.01 & -0.01 & 0.00 \\
\hline retail & 0.10 & 0.10 & 0.10 & 0.10 & 0.10 & 0.12 & 0.00 & 0.00 & 0.00 \\
\hline transport, telecommunication & 0.09 & 0.08 & 0.08 & 0.09 & 0.08 & 0.08 & 0.01 & 0.00 & 0.01 \\
\hline banking and insurance & 0.02 & 0.02 & 0.02 & 0.02 & 0.02 & 0.01 & 0.00 & 0.00 & 0.00 \\
\hline services & 0.21 & 0.23 & 0.22 & 0.25 & 0.26 & 0.33 & -0.02 & 0.00 & -0.01 \\
\hline adm., non-profit and p.h. & 0.17 & 0.16 & 0.16 & 0.13 & 0.13 & 0.07 & 0.00 & 0.00 & 0.00 \\
\hline shrinking workforce $\quad$ yes $=1$ & 0.71 & 0.71 & 0.70 & 0.61 & 0.61 & 0.55 & 0.00 & 0.01 & 0.00 \\
\hline \multirow{4}{*}{$\begin{array}{r}\text { occupation group imple manual } \\
\text { qualified manual } \\
\text { tech. and engineers } \\
\text { simple services }\end{array}$} & 0.18 & 0.16 & 0.18 & 0.18 & 0.17 & 0.19 & 0.02 & 0.00 & 0.00 \\
\hline & 0.22 & 0.22 & 0.22 & 0.21 & 0.21 & 0.19 & 0.00 & 0.00 & 0.00 \\
\hline & 0.05 & 0.06 & 0.05 & 0.06 & 0.06 & 0.06 & -0.01 & 0.00 & 0.00 \\
\hline & 0.14 & 0.14 & 0.14 & 0.14 & 0.14 & 0.14 & 0.00 & 0.00 & 0.00 \\
\hline qualified services & 0.05 & 0.05 & 0.05 & 0.05 & 0.05 & 0.06 & 0.00 & 0.00 & 0.00 \\
\hline & 0.07 & 0.07 & 0.07 & 0.07 & 0.07 & 0.07 & 0.00 & 0.00 & 0.00 \\
\hline professions & 0.01 & 0.01 & 0.01 & 0.01 & 0.01 & 0.01 & 0.00 & 0.00 & 0.00 \\
\hline simp. sales a. adm. & 0.06 & 0.07 & 0.06 & 0.07 & 0.07 & 0.06 & 0.00 & 0.00 & 0.00 \\
\hline qual. sales a. adm. & 0.18 & 0.19 & 0.18 & 0.18 & 0.18 & 0.18 & -0.01 & 0.00 & 0.00 \\
\hline \multirow{2}{*}{$\begin{array}{r}\text { manager } \\
\text { miscellaneous }\end{array}$} & 0.02 & 0.03 & 0.02 & 0.02 & 0.02 & 0.02 & 0.00 & 0.00 & 0.00 \\
\hline & 0.01 & 0.01 & 0.01 & 0.00 & 0.00 & 0.01 & 0.00 & 0.00 & 0.00 \\
\hline occupation change & 0.23 & 0.24 & 0.22 & 0.17 & 0.18 & 0.13 & -0.02 & 0.00 & -0.01 \\
\hline indus try change & 0.24 & 0.28 & 0.24 & 0.18 & 0.19 & 0.13 & -0.04 & 0.00 & -0.01 \\
\hline \multirow{2}{*}{$\begin{array}{rr}\text { Region } & \text { Berlin } \\
& \text { Brandenburg }\end{array}$} & 0.15 & 0.18 & 0.16 & 0.16 & 0.16 & 0.16 & -0.03 & -0.01 & 0.00 \\
\hline & 0.15 & 0.14 & 0.15 & 0.15 & 0.15 & 0.15 & 0.01 & 0.00 & 0.00 \\
\hline Mecklenburg-West Pomerania & 0.10 & 0.10 & 0.10 & 0.10 & 0.10 & 0.10 & 0.01 & 0.00 & 0.00 \\
\hline \multirow{2}{*}{$\begin{array}{r}\text { Saxony } \\
\text { Saxony-Anhalt }\end{array}$} & 0.28 & 0.27 & 0.27 & 0.27 & 0.27 & 0.28 & 0.00 & 0.00 & 0.00 \\
\hline & 0.17 & 0.16 & 0.17 & 0.17 & 0.16 & 0.16 & 0.01 & 0.00 & 0.01 \\
\hline $\begin{array}{r}\text { Saxony-Anhalt } \\
\text { Thuringia }\end{array}$ & 0.15 & 0.14 & 0.15 & 0.15 & 0.15 & 0.16 & 0.00 & 0.00 & 0.00 \\
\hline
\end{tabular}

Source: SIAB (1975-2008). 
Table EA.1.B Descriptive Statistics and Results of the Reweighting Step (West Germany): Mean Values of Observed Characteristics

\begin{tabular}{|c|c|c|c|c|c|c|c|c|c|c|}
\hline & & base 1993 & $\begin{array}{c}\text { base } 2004 \\
\text { reweighted } \\
\text { to } 1993 \\
\text { B }\end{array}$ & $\begin{array}{c}\text { base } 1998 \\
\text { reweighted } \\
\text { to } 1993 \\
\text { C }\end{array}$ & base 1998 & $\begin{array}{c}\text { base } 2004 \\
\text { reweighted } \\
\text { to } 1998 \\
\text { E }\end{array}$ & $\begin{array}{c}\text { base } 2004 \\
\text { F }\end{array}$ & diff. & diff. & diff. \\
\hline \multicolumn{11}{|l|}{$\overline{Z Z \text { - Individual }}$} \\
\hline \multirow[t]{6}{*}{ age } & $25-30$ & 0.27 & 0.27 & 0.27 & 0.22 & 0.21 & 0.16 & 0.00 & 0.00 & 0.00 \\
\hline & $31-35$ & 0.19 & 0.19 & 0.19 & 0.21 & 0.21 & 0.16 & 0.00 & 0.00 & 0.00 \\
\hline & $36-40$ & 0.16 & 0.16 & 0.16 & 0.19 & 0.19 & 0.20 & 0.00 & 0.00 & 0.00 \\
\hline & $41-45$ & 0.14 & 0.15 & 0.14 & 0.16 & 0.16 & 0.19 & 0.00 & 0.00 & 0.00 \\
\hline & $46-50$ & 0.11 & 0.11 & 0.11 & 0.14 & 0.14 & 0.16 & 0.00 & 0.00 & 0.00 \\
\hline & $>50$ & 0.13 & 0.13 & 0.13 & 0.10 & 0.10 & 0.13 & 0.00 & 0.00 & 0.00 \\
\hline \multirow[t]{10}{*}{ start position } & $1-10$ & 0.08 & 0.08 & 0.08 & 0.08 & 0.08 & 0.07 & 0.00 & 0.00 & 0.00 \\
\hline & $11-20$ & 0.09 & 0.09 & 0.09 & 0.09 & 0.09 & 0.09 & 0.00 & 0.00 & 0.00 \\
\hline & $21-30$ & 0.10 & 0.10 & 0.10 & 0.10 & 0.10 & 0.10 & 0.00 & 0.00 & 0.00 \\
\hline & $31-40$ & 0.11 & 0.11 & 0.11 & 0.11 & 0.11 & 0.11 & 0.00 & 0.00 & 0.00 \\
\hline & $41-50$ & 0.11 & 0.11 & 0.11 & 0.11 & 0.11 & 0.11 & 0.00 & 0.00 & 0.00 \\
\hline & $51-60$ & 0.11 & 0.11 & 0.11 & 0.11 & 0.11 & 0.11 & 0.00 & 0.00 & 0.00 \\
\hline & $61-70$ & 0.11 & 0.11 & 0.11 & 0.11 & 0.11 & 0.11 & 0.00 & 0.00 & 0.00 \\
\hline & $71-80$ & 0.11 & 0.11 & 0.11 & 0.11 & 0.11 & 0.11 & 0.00 & 0.00 & 0.00 \\
\hline & $81-90$ & 0.11 & 0.11 & 0.10 & 0.10 & 0.10 & 0.11 & 0.00 & 0.00 & 0.00 \\
\hline & $91-100$ & 0.08 & 0.08 & 0.08 & 0.08 & 0.08 & 0.08 & 0.00 & 0.00 & 0.00 \\
\hline \multirow[t]{3}{*}{ education } & low & 0.16 & 0.16 & 0.16 & 0.13 & 0.13 & 0.11 & 0.00 & 0.00 & 0.00 \\
\hline & medium & 0.81 & 0.81 & 0.81 & 0.82 & 0.82 & 0.83 & 0.00 & 0.00 & 0.00 \\
\hline & high & 0.03 & 0.03 & 0.03 & 0.05 & 0.05 & 0.06 & 0.00 & 0.00 & 0.00 \\
\hline \multirow{2}{*}{$\begin{array}{l}\text { citizenship } \\
\text { sex }\end{array}$} & non-german & 0.10 & 0.11 & 0.10 & 0.09 & 0.09 & 0.08 & 0.00 & 0.00 & 0.00 \\
\hline & female & 0.33 & 0.34 & 0.33 & 0.33 & 0.33 & 0.33 & -0.01 & 0.00 & 0.00 \\
\hline \multicolumn{11}{|l|}{ J - Job Stability } \\
\hline firm change & yes $=1$ & 0.29 & 0.29 & 0.30 & 0.34 & 0.33 & 0.30 & 0.00 & 0.00 & 0.00 \\
\hline \multirow[t]{4}{*}{ unemployment } & not unemployed & 0.81 & 0.81 & 0.81 & 0.82 & 0.81 & 0.80 & 0.00 & 0.00 & 0.00 \\
\hline & 0-0.5 year & 0.09 & 0.09 & 0.09 & 0.09 & 0.09 & 0.08 & 0.00 & 0.00 & 0.00 \\
\hline & $0.5-1$ year & 0.05 & 0.05 & 0.05 & 0.04 & 0.05 & 0.05 & 0.00 & 0.00 & 0.00 \\
\hline & $>1$ year & 0.05 & 0.05 & 0.05 & 0.05 & 0.05 & 0.06 & 0.00 & 0.00 & 0.00 \\
\hline \multirow[t]{4}{*}{ tenure } & $<0.5$ year & 0.05 & 0.05 & 0.05 & 0.06 & 0.06 & 0.06 & 0.00 & 0.00 & 0.00 \\
\hline & 0.5-1 year & 0.10 & 0.10 & 0.10 & 0.12 & 0.12 & 0.08 & 0.00 & 0.00 & 0.00 \\
\hline & 1-2 years & 0.11 & 0.11 & 0.11 & 0.12 & 0.12 & 0.12 & 0.00 & 0.00 & 0.00 \\
\hline & $>2$ years & 0.74 & 0.74 & 0.74 & 0.69 & 0.69 & 0.74 & 0.00 & 0.00 & 0.00 \\
\hline
\end{tabular}




\begin{tabular}{|c|c|c|c|c|c|c|c|c|c|}
\hline \multicolumn{10}{|l|}{$\begin{array}{l}\text { E- Employer and Employment } \\
\text { firm size }\end{array}$} \\
\hline 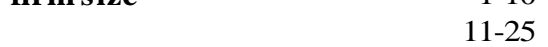 & 0.12 & 0.12 & 0.13 & 0.13 & 0.13 & 0.13 & 0.00 & 0.00 & 0.00 \\
\hline $26-50$ & 0.10 & 0.10 & 0.10 & 0.11 & 0.11 & 0.12 & 0.00 & 0.00 & 0.00 \\
\hline $51-100$ & 0.11 & 0.11 & 0.11 & 0.11 & 0.11 & 0.13 & 0.00 & 0.00 & 0.00 \\
\hline $101-1000$ & 0.33 & 0.33 & 0.33 & 0.33 & 0.33 & 0.35 & 0.00 & 0.00 & 0.00 \\
\hline$>1000$ & 0.16 & 0.16 & 0.16 & 0.14 & 0.14 & 0.13 & 0.00 & 0.01 & 0.00 \\
\hline agriculture & 0.01 & 0.01 & 0.01 & 0.01 & 0.01 & 0.01 & 0.00 & 0.00 & 0.00 \\
\hline energy, water, mining & 0.02 & 0.02 & 0.02 & 0.02 & 0.02 & 0.01 & 0.00 & 0.00 & 0.00 \\
\hline manufacturing & 0.40 & 0.39 & 0.40 & 0.38 & 0.38 & 0.33 & 0.01 & 0.00 & 0.00 \\
\hline construction & 0.08 & 0.08 & 0.09 & 0.08 & 0.08 & 0.08 & 0.00 & -0.01 & 0.00 \\
\hline retail & 0.13 & 0.13 & 0.13 & 0.13 & 0.13 & 0.15 & 0.00 & 0.00 & 0.00 \\
\hline transport, telecommunication & 0.06 & 0.06 & 0.06 & 0.06 & 0.06 & 0.07 & 0.00 & 0.00 & 0.00 \\
\hline banking and insurance & 0.03 & 0.03 & 0.03 & 0.03 & 0.03 & 0.03 & 0.00 & 0.00 & 0.00 \\
\hline services & 0.19 & 0.19 & 0.18 & 0.22 & 0.21 & 0.27 & 0.00 & 0.01 & 0.00 \\
\hline adm., non-profit and p.h. & 0.08 & 0.09 & 0.08 & 0.08 & 0.08 & 0.06 & 0.00 & 0.00 & 0.00 \\
\hline shrinking workforce $\quad$ yes $=1$ & 0.65 & 0.65 & 0.65 & 0.44 & 0.44 & 0.53 & 0.00 & 0.00 & 0.00 \\
\hline \multirow[t]{11}{*}{ occupation group } & 0.23 & 0.22 & 0.23 & 0.22 & 0.22 & 0.21 & 0.01 & 0.00 & 0.00 \\
\hline & 0.23 & 0.22 & 0.23 & 0.22 & 0.22 & 0.20 & 0.00 & 0.00 & 0.00 \\
\hline & 0.05 & 0.05 & 0.05 & 0.06 & 0.06 & 0.06 & 0.00 & 0.00 & 0.00 \\
\hline & 0.14 & 0.14 & 0.14 & 0.14 & 0.14 & 0.14 & 0.00 & 0.00 & 0.00 \\
\hline & 0.04 & 0.04 & 0.04 & 0.04 & 0.04 & 0.04 & 0.00 & 0.00 & 0.00 \\
\hline & 0.04 & 0.05 & 0.04 & 0.05 & 0.05 & 0.06 & 0.00 & 0.00 & 0.00 \\
\hline & 0.01 & 0.01 & 0.01 & 0.01 & 0.01 & 0.01 & 0.00 & 0.00 & 0.00 \\
\hline & 0.07 & 0.07 & 0.07 & 0.07 & 0.07 & 0.06 & 0.00 & 0.00 & 0.00 \\
\hline & 0.17 & 0.18 & 0.17 & 0.18 & 0.18 & 0.20 & 0.00 & 0.00 & 0.00 \\
\hline & 0.01 & 0.01 & 0.01 & 0.01 & 0.01 & 0.02 & 0.00 & 0.00 & 0.00 \\
\hline & 0.00 & 0.00 & 0.00 & 0.00 & 0.00 & 0.00 & 0.00 & 0.00 & 0.00 \\
\hline occupation change & 0.13 & 0.13 & 0.13 & 0.14 & 0.14 & 0.12 & 0.00 & 0.00 & 0.00 \\
\hline indus try change & 0.13 & 0.13 & 0.13 & 0.14 & 0.14 & 0.13 & 0.00 & 0.00 & 0.00 \\
\hline \multirow[t]{9}{*}{ R - Region } & 0.04 & 0.04 & 0.04 & 0.04 & 0.04 & 0.04 & 0.00 & 0.00 & 0.00 \\
\hline & 0.03 & 0.03 & 0.03 & 0.03 & 0.03 & 0.03 & 0.00 & 0.00 & 0.00 \\
\hline & 0.11 & 0.11 & 0.11 & 0.11 & 0.11 & 0.12 & 0.00 & 0.00 & 0.00 \\
\hline & 0.01 & 0.01 & 0.01 & 0.01 & 0.01 & 0.01 & 0.00 & 0.00 & 0.00 \\
\hline & 0.28 & 0.27 & 0.28 & 0.28 & 0.28 & 0.27 & 0.00 & 0.00 & 0.00 \\
\hline & 0.10 & 0.10 & 0.09 & 0.09 & 0.09 & 0.09 & 0.00 & 0.00 & 0.00 \\
\hline & 0.06 & 0.06 & 0.06 & 0.06 & 0.06 & 0.06 & 0.00 & 0.00 & 0.00 \\
\hline & 0.17 & 0.17 & 0.17 & 0.17 & 0.17 & 0.17 & 0.00 & 0.00 & 0.00 \\
\hline & 0.19 & 0.19 & 0.19 & 0.19 & 0.19 & 0.19 & 0.00 & 0.00 & 0.00 \\
\hline Saarland & 0.02 & 0.02 & 0.02 & 0.02 & 0.02 & 0.02 & 0.00 & 0.00 & 0.00 \\
\hline
\end{tabular}

Source: SIAB (1975-2008). 
Table EA.2 RIF Regressions for East and West Germany

\begin{tabular}{|c|c|c|c|c|c|c|c|c|c|c|c|c|}
\hline & \multicolumn{6}{|c|}{ East Germany } & \multicolumn{6}{|c|}{ West Germany } \\
\hline & 1993 & & 1998 & & 2004 & & 1993 & & 1998 & & 2004 & \\
\hline age 31-35 & $\begin{array}{l}-28.45 \\
(9.77)\end{array}$ & $* * *$ & $\begin{array}{c}-69.23 \\
(8.95)\end{array}$ & $* * *$ & $\begin{array}{l}-48.83 \\
(10.09)\end{array}$ & $* * *$ & $\begin{array}{c}-60.73 \\
(4.51)\end{array}$ & $* * *$ & $\begin{array}{c}-92.68 \\
(4.87)\end{array}$ & $* * *$ & $\begin{array}{c}-71.08 \\
(5.05)\end{array}$ & $* * *$ \\
\hline age $36-40$ & $\begin{array}{l}-41.51 \\
(10.02)\end{array}$ & $* * *$ & $\begin{array}{c}-98.63 \\
(8.87)\end{array}$ & $* * *$ & $\begin{array}{c}-88.65 \\
(9.50)\end{array}$ & $* * *$ & $\begin{array}{l}-81.57 \\
(4.83)\end{array}$ & $* * *$ & $\begin{array}{c}-123.30 \\
(5.07)\end{array}$ & $* * *$ & $\begin{array}{c}-101.00 \\
(4.87)\end{array}$ & $* * *$ \\
\hline age $41-45$ & $\begin{array}{l}-64.79 \\
(10.50)\end{array}$ & $* * *$ & $\begin{array}{c}-106.80 \\
(9.13)\end{array}$ & $* * *$ & $\begin{array}{l}-98.68 \\
(9.33)\end{array}$ & $* * *$ & $\begin{array}{c}-89.33 \\
(4.97)\end{array}$ & $* * *$ & $\begin{array}{c}-129.80 \\
(5.36)\end{array}$ & $* * *$ & $\begin{array}{c}-115.10 \\
(4.95)\end{array}$ & $* * *$ \\
\hline age $46-50$ & $\begin{array}{l}-70.22 \\
(11.55)\end{array}$ & $* * *$ & $\begin{array}{c}-115.20 \\
(9.54)\end{array}$ & $* * *$ & $\begin{array}{c}-101.40 \\
(9.63)\end{array}$ & $* * *$ & $\begin{array}{l}-92.18 \\
(5.43)\end{array}$ & $* * *$ & $\begin{array}{c}-131.70 \\
(5.59)\end{array}$ & $* * *$ & $\begin{array}{c}-108.90 \\
(5.22)\end{array}$ & $* * *$ \\
\hline age $>50$ & $\begin{array}{l}-98.47 \\
(11.23)\end{array}$ & $* * *$ & $\begin{array}{r}-101.20 \\
(10.56)\end{array}$ & $* * *$ & $\begin{array}{c}-109.20 \\
(9.95)\end{array}$ & $* * *$ & $\begin{array}{l}-91.07 \\
(5.30)\end{array}$ & $* * *$ & $\begin{array}{c}-114.80 \\
(6.25)\end{array}$ & $* * *$ & $\begin{array}{c}-103.30 \\
(5.50)\end{array}$ & $* * *$ \\
\hline start pos. $11-20$ & $\begin{array}{c}26.16 \\
(15.51)\end{array}$ & * & $\begin{array}{l}-61.50 \\
(13.42)\end{array}$ & $* * *$ & $\begin{array}{l}-17.43 \\
(13.11)\end{array}$ & & $\begin{array}{l}12.87 \\
(7.51)\end{array}$ & $*$ & $\begin{array}{l}-17.31 \\
(7.80)\end{array}$ & $* *$ & $\begin{array}{l}-21.70 \\
(7.13)\end{array}$ & $* * *$ \\
\hline start pos. $21-30$ & $\begin{array}{c}47.57 \\
(15.59)\end{array}$ & $* * *$ & $\begin{array}{l}-71.53 \\
(13.18)\end{array}$ & $* * *$ & $\begin{array}{l}-18.31 \\
(13.00)\end{array}$ & & $\begin{array}{l}84.59 \\
(7.52)\end{array}$ & $* * *$ & $\begin{array}{l}-9.13 \\
(7.78)\end{array}$ & & $\begin{array}{l}-5.21 \\
(7.13)\end{array}$ & \\
\hline start pos. 31-40 & $\begin{array}{c}67.78 \\
(15.58)\end{array}$ & $* * *$ & $\begin{array}{l}-87.90 \\
(13.31)\end{array}$ & $* * *$ & $\begin{array}{l}-15.38 \\
(13.10)\end{array}$ & & $\begin{array}{c}101.70 \\
(7.59)\end{array}$ & $* * *$ & $\begin{array}{c}2.09 \\
(7.89)\end{array}$ & & $\begin{array}{l}20.03 \\
(7.21)\end{array}$ & $* * *$ \\
\hline start pos. $41-50$ & $\begin{array}{c}96.11 \\
(15.78)\end{array}$ & $* * *$ & $\begin{array}{l}-56.26 \\
(13.34)\end{array}$ & $* * *$ & $\begin{array}{c}3.59 \\
(13.26)\end{array}$ & & $\begin{array}{c}129.90 \\
(7.68)\end{array}$ & $* * *$ & $\begin{array}{l}17.81 \\
(7.99)\end{array}$ & $* *$ & $\begin{array}{l}45.86 \\
(7.32)\end{array}$ & $* * *$ \\
\hline start pos. 51-60 & $\begin{array}{l}109.70 \\
(15.96)\end{array}$ & $* * *$ & $\begin{array}{l}-14.41 \\
(13.45)\end{array}$ & & $\begin{array}{c}43.75 \\
(13.34)\end{array}$ & $* * *$ & $\begin{array}{c}133.00 \\
(7.78)\end{array}$ & $* * *$ & $\begin{array}{l}19.67 \\
(8.09)\end{array}$ & $* *$ & $\begin{array}{l}55.61 \\
(7.41)\end{array}$ & $* * *$ \\
\hline start pos. $61-70$ & $\begin{array}{l}120.50 \\
(16.20)\end{array}$ & $* * *$ & $\begin{array}{c}-3.40 \\
(13.58)\end{array}$ & & $\begin{array}{c}54.38 \\
(13.58)\end{array}$ & $* * *$ & $\begin{array}{c}152.90 \\
(7.88)\end{array}$ & $* * *$ & $\begin{array}{l}26.17 \\
(8.19)\end{array}$ & $* * *$ & $\begin{array}{l}72.22 \\
(7.52)\end{array}$ & $* * *$ \\
\hline start pos. $71-80$ & $\begin{array}{l}162.00 \\
(16.61)\end{array}$ & $* * *$ & $\begin{array}{c}10.15 \\
(13.87)\end{array}$ & & $\begin{array}{c}51.97 \\
(13.88)\end{array}$ & $* * *$ & $\begin{array}{c}159.10 \\
(7.98)\end{array}$ & $* * *$ & $\begin{array}{l}27.36 \\
(8.32)\end{array}$ & $* * *$ & $\begin{array}{l}61.01 \\
(7.63)\end{array}$ & $* * *$ \\
\hline start pos. $81-90$ & $\begin{array}{l}147.70 \\
(17.01)\end{array}$ & $* * *$ & $\begin{array}{c}-8.27 \\
(14.27)\end{array}$ & & $\begin{array}{c}30.12 \\
(14.21)\end{array}$ & $* *$ & $\begin{array}{c}173.90 \\
(8.17)\end{array}$ & $* * *$ & $\begin{array}{l}29.16 \\
(8.54)\end{array}$ & $* * *$ & $\begin{array}{l}32.95 \\
(7.85)\end{array}$ & $* * *$ \\
\hline start pos. $91-100$ & $\begin{array}{l}146.00 \\
(18.27)\end{array}$ & $* * *$ & $\begin{array}{l}-42.52 \\
(15.25)\end{array}$ & $* * *$ & $\begin{array}{c}38.32 \\
(15.11)\end{array}$ & $* *$ & $\begin{array}{c}203.70 \\
(8.76)\end{array}$ & $* * *$ & $\begin{array}{l}36.48 \\
(9.05)\end{array}$ & $* * *$ & $\begin{array}{l}33.52 \\
(8.42)\end{array}$ & $* * *$ \\
\hline educ mid & $\begin{array}{c}16.37 \\
(14.16)\end{array}$ & & $\begin{array}{c}11.39 \\
(15.04)\end{array}$ & & $\begin{array}{c}31.55 \\
(16.43)\end{array}$ & * & $\begin{array}{l}29.70 \\
(4.63)\end{array}$ & $* * *$ & $\begin{array}{l}35.88 \\
(5.15)\end{array}$ & $* * *$ & $\begin{array}{l}33.72 \\
(4.96)\end{array}$ & $* * *$ \\
\hline educ high & $\begin{array}{c}18.22 \\
(18.84)\end{array}$ & & $\begin{array}{c}52.03 \\
(17.99)\end{array}$ & $* * *$ & $\begin{array}{c}84.23 \\
(18.80)\end{array}$ & $* * *$ & $\begin{array}{c}94.25 \\
(10.00)\end{array}$ & $* * *$ & $\begin{array}{c}162.70 \\
(9.55)\end{array}$ & $* * *$ & $\begin{array}{l}130.20 \\
(8.08)\end{array}$ & $* * *$ \\
\hline non german & $\begin{array}{l}104.00 \\
(26.99)\end{array}$ & $* * *$ & $\begin{array}{c}23.88 \\
(24.92)\end{array}$ & & $\begin{array}{l}-41.85 \\
(25.51)\end{array}$ & & $\begin{array}{l}35.30 \\
(5.26)\end{array}$ & $* * *$ & $\begin{array}{l}19.74 \\
(5.87)\end{array}$ & $* * *$ & $\begin{array}{l}-5.05 \\
(5.52)\end{array}$ & \\
\hline female & $\begin{array}{l}-46.23 \\
(8.56)\end{array}$ & $* * *$ & $\begin{array}{l}-29.30 \\
(7.10)\end{array}$ & $* * *$ & $\begin{array}{l}-1.95 \\
(6.66)\end{array}$ & & $\begin{array}{c}4.42 \\
(4.19)\end{array}$ & & $\begin{array}{l}-21.07 \\
(4.28)\end{array}$ & $* * *$ & $\begin{array}{l}11.27 \\
(3.80)\end{array}$ & $* * *$ \\
\hline migrates west & $\begin{array}{c}43.56 \\
(11.69)\end{array}$ & $* * *$ & $\begin{array}{c}68.50 \\
(12.07)\end{array}$ & $* * *$ & $\begin{array}{c}30.05 \\
(27.30)\end{array}$ & & - & & - & & - & \\
\hline firm change & $\begin{array}{l}125.70 \\
(8.24)\end{array}$ & $* * *$ & $\begin{array}{c}156.50 \\
(7.41)\end{array}$ & $* * *$ & $\begin{array}{l}133.30 \\
(7.28)\end{array}$ & $* * *$ & $\begin{array}{c}167.90 \\
(4.33)\end{array}$ & $* * *$ & $\begin{array}{c}177.80 \\
(4.53)\end{array}$ & $* * *$ & $\begin{array}{c}169.70 \\
(4.26)\end{array}$ & $* * *$ \\
\hline unempl. 0-0.5 yr & $\begin{array}{c}126.20 \\
(9.89)\end{array}$ & $* * *$ & $\begin{array}{l}86.04 \\
(9.28)\end{array}$ & $* * *$ & $\begin{array}{c}106.70 \\
(9.40)\end{array}$ & $* * *$ & $\begin{array}{c}113.00 \\
(5.73)\end{array}$ & $* * *$ & $\begin{array}{l}68.17 \\
(5.94)\end{array}$ & $* * *$ & $\begin{array}{l}93.95 \\
(5.83)\end{array}$ & $* * *$ \\
\hline
\end{tabular}




\begin{tabular}{|c|c|c|c|c|c|c|c|c|c|c|c|c|}
\hline unen & $\begin{array}{l}217.50 \\
(12.85)\end{array}$ & $* * *$ & $\begin{array}{l}142.80 \\
(11.41)\end{array}$ & $* * *$ & $\begin{array}{l}153.10 \\
(10.94)\end{array}$ & & $\begin{array}{c}164.30 \\
(7.70)\end{array}$ & $* * *$ & $\begin{array}{l}72.26 \\
(8.17)\end{array}$ & $* * *$ & $\begin{array}{r}137.80 \\
(7.12)\end{array}$ & \\
\hline unempl. > 1 yr & $\begin{array}{l}265.30 \\
(12.09)\end{array}$ & $* * *$ & $\begin{array}{l}149.80 \\
(10.85)\end{array}$ & $* * *$ & $\begin{array}{c}139.60 \\
(9.77)\end{array}$ & $* * *$ & $\begin{array}{c}240.20 \\
(7.71)\end{array}$ & $* * *$ & $\begin{array}{l}57.93 \\
(8.31)\end{array}$ & $* * *$ & $\begin{array}{l}90.33 \\
(6.98)\end{array}$ & $* * *$ \\
\hline tenure $0.5-1$ yr & $\begin{array}{l}-29.91 \\
(14.56)\end{array}$ & $* *$ & $\begin{array}{c}-62.01 \\
(12.15)\end{array}$ & $* * *$ & $\begin{array}{l}-59.21 \\
(12.84)\end{array}$ & $* * *$ & $\begin{array}{l}-93.60 \\
(8.26)\end{array}$ & $* * *$ & $\begin{array}{c}-156.70 \\
(7.88)\end{array}$ & $* * *$ & $\begin{array}{r}-87.10 \\
(7.93)\end{array}$ & $* * *$ \\
\hline tenure $1-2$ yr & $\begin{array}{c}6.03 \\
(14.37)\end{array}$ & & $\begin{array}{l}-25.03 \\
(12.67)\end{array}$ & $* *$ & $\begin{array}{c}-55.41 \\
(12.48)\end{array}$ & $* * *$ & $\begin{array}{c}-90.93 \\
(8.23)\end{array}$ & $* * *$ & $\begin{array}{c}-174.60 \\
(8.05)\end{array}$ & $* * *$ & $\begin{array}{r}-87.62 \\
(7.61)\end{array}$ & $* * *$ \\
\hline tenure $>2$ yrs & $\begin{array}{c}-24.63 \\
(14.11)\end{array}$ & $*$ & $\begin{array}{l}-31.91 \\
(11.54)\end{array}$ & $* * *$ & $\begin{array}{l}-74.56 \\
(11.42)\end{array}$ & $* * *$ & $\begin{array}{c}-133.30 \\
(7.42)\end{array}$ & $* * *$ & $\begin{array}{c}-209.30 \\
(7.27)\end{array}$ & $* * *$ & $\begin{aligned} & -117 \\
& (6.9\end{aligned}$ & $* * *$ \\
\hline firm size $11-25$ & $\begin{array}{l}-22.90 \\
(11.77)\end{array}$ & $*$ & $\begin{array}{l}16.08 \\
(9.01)\end{array}$ & $*$ & $\begin{array}{l}-12.14 \\
(8.77)\end{array}$ & & $\begin{array}{l}-4.05 \\
(5.70)\end{array}$ & & $\begin{array}{c}8.00 \\
(5.81)\end{array}$ & & $\begin{array}{c}2.20 \\
(5.41)\end{array}$ & \\
\hline firm size $26-50$ & $\begin{array}{c}-35.67 \\
(12.41)\end{array}$ & $* * *$ & $\begin{array}{l}22.36 \\
(9.68)\end{array}$ & $* *$ & $\begin{array}{l}12.95 \\
(9.24)\end{array}$ & & $\begin{array}{l}-0.11 \\
(6.10)\end{array}$ & & $\begin{array}{c}9.73 \\
(6.17)\end{array}$ & & $\begin{array}{l}19.83 \\
(5.72)\end{array}$ & $* * *$ \\
\hline firm size $51-100$ & $\begin{array}{l}-22.59 \\
(12.39)\end{array}$ & * & $\begin{array}{l}34.40 \\
(9.74)\end{array}$ & $* * *$ & $\begin{array}{c}7.45 \\
(9.33)\end{array}$ & & $\begin{array}{c}0.58 \\
(6.07)\end{array}$ & & $\begin{array}{l}20.83 \\
(6.13)\end{array}$ & $* * *$ & $\begin{array}{l}13.84 \\
(5.67)\end{array}$ & $* *$ \\
\hline firm size $101-1000$ & $\begin{array}{l}-17.15 \\
(10.51)\end{array}$ & & $\begin{array}{l}17.06 \\
(8.51)\end{array}$ & $* *$ & $\begin{array}{l}26.69 \\
(8.25)\end{array}$ & $* * *$ & $\begin{array}{l}-13.90 \\
(5.06)\end{array}$ & $* * *$ & $\begin{array}{l}12.84 \\
(5.11)\end{array}$ & $* *$ & $\begin{array}{l}20.67 \\
(4.92)\end{array}$ & $* * *$ \\
\hline firm size $>1000$ & $\begin{array}{c}23.48 \\
(13.24)\end{array}$ & $*$ & $\begin{array}{l}-41.29 \\
(12.02)\end{array}$ & $* * *$ & $\begin{array}{c}-8.85 \\
(12.82)\end{array}$ & & $\begin{array}{l}-37.77 \\
(6.12)\end{array}$ & $* * *$ & $\begin{array}{c}3.86 \\
(6.46)\end{array}$ & & $\begin{array}{l}32.44 \\
(6.25)\end{array}$ & $* * *$ \\
\hline sector: agriculture & $\begin{array}{l}-97.80 \\
(29.33)\end{array}$ & $* * *$ & $\begin{array}{r}-105.40 \\
(24.26)\end{array}$ & $* * *$ & $\begin{array}{l}-52.76 \\
(16.11)\end{array}$ & $* * *$ & $\begin{array}{r}-109.30 \\
(18.01)\end{array}$ & $* * *$ & $\begin{array}{c}-138.20 \\
(18.71)\end{array}$ & $* * *$ & & $* * *$ \\
\hline sector: energy water m. & $\begin{array}{l}173.10 \\
(21.49)\end{array}$ & $* * *$ & $\begin{array}{c}-6.54 \\
(21.78)\end{array}$ & & $\begin{array}{l}-43.44 \\
(22.49)\end{array}$ & * & $\begin{array}{l}-38.90 \\
(12.05)\end{array}$ & $* * *$ & $\begin{array}{l}-45.72 \\
(13.24)\end{array}$ & $* * *$ & $\begin{array}{c}-0.96 \\
(12.82)\end{array}$ & \\
\hline sector: manufacturing & $\begin{array}{l}156.80 \\
(10.77)\end{array}$ & $* * *$ & $\begin{array}{l}-0.99 \\
(8.94)\end{array}$ & & $\begin{array}{l}-1.89 \\
(8.48)\end{array}$ & & $\begin{array}{l}17.13 \\
(5.23)\end{array}$ & $* * *$ & $\begin{array}{r}-15.91 \\
(5.31)\end{array}$ & $* * *$ & $\begin{array}{l}13.61 \\
(4.68)\end{array}$ & *** \\
\hline sector: construction & $\begin{array}{c}61.30 \\
(12.59)\end{array}$ & $* * *$ & $\begin{array}{c}-5.43 \\
(10.78)\end{array}$ & & $\begin{array}{l}-54.18 \\
(10.48)\end{array}$ & $* * *$ & $\begin{array}{c}2.35 \\
(7.20)\end{array}$ & & $\begin{array}{l}-18.34 \\
(7.60)\end{array}$ & $* *$ & $\begin{array}{l}-30.79 \\
(6.71)\end{array}$ & \\
\hline sector: retail & $\begin{array}{c}47.58 \\
(13.23)\end{array}$ & $* * *$ & $\begin{array}{c}-9.32 \\
(10.76)\end{array}$ & & $\begin{array}{l}-8.41 \\
(9.72)\end{array}$ & & $\begin{array}{l}-20.44 \\
(6.01)\end{array}$ & $* * *$ & $\begin{array}{l}-39.51 \\
(6.06)\end{array}$ & $* * *$ & $\begin{array}{r}-27.56 \\
(5.15)\end{array}$ & \\
\hline sector: transp. comm. & $\begin{array}{l}-61.59 \\
(13.58)\end{array}$ & $* * *$ & $\begin{array}{l}-29.13 \\
(11.16)\end{array}$ & $* * *$ & $\begin{array}{l}-29.42 \\
(10.67)\end{array}$ & $* * *$ & $\begin{array}{l}-38.46 \\
(7.58)\end{array}$ & $* * *$ & $\begin{array}{r}-32.78 \\
(7.71)\end{array}$ & $* * *$ & $\begin{array}{r}-34.78 \\
(6.64)\end{array}$ & $* * *$ \\
\hline sector: bank., insur. & $\begin{array}{c}85.56 \\
(27.31)\end{array}$ & $* * *$ & $\begin{array}{c}15.33 \\
(21.90)\end{array}$ & & $\begin{array}{c}16.78 \\
(23.00)\end{array}$ & & $\begin{array}{l}-24.24 \\
(10.12)\end{array}$ & $* *$ & $\begin{array}{c}-44.47 \\
(10.56)\end{array}$ & $* * *$ & $\begin{array}{c}0.30 \\
(9.57)\end{array}$ & \\
\hline sector: adm, non-profit & $\begin{array}{c}-83.84 \\
(10.90)\end{array}$ & $* * *$ & $\begin{array}{c}-66.74 \\
(9.75)\end{array}$ & $* * *$ & $\begin{array}{l}-76.69 \\
(11.22)\end{array}$ & $* * *$ & $\begin{array}{l}-66.32 \\
(6.53)\end{array}$ & $* * *$ & $\begin{array}{c}-97.64 \\
(6.83)\end{array}$ & $* * *$ & $\begin{array}{r}-71.68 \\
(6.92)\end{array}$ & \\
\hline shrinking workforce & $\begin{array}{l}-23.70 \\
(7.87)\end{array}$ & $* * *$ & $\begin{array}{l}-39.87 \\
(6.03)\end{array}$ & $* * *$ & $\begin{array}{l}-31.97 \\
(5.54)\end{array}$ & $* * *$ & $\begin{array}{l}-19.12 \\
(3.33)\end{array}$ & $* * *$ & $\begin{array}{l}-23.87 \\
(3.45)\end{array}$ & $* * *$ & $\begin{array}{r}-32.43 \\
(3.01)\end{array}$ & \\
\hline occup: qual. manual & $\begin{array}{c}-20.91 \\
(10.27)\end{array}$ & $* *$ & $\begin{array}{l}11.92 \\
(8.70)\end{array}$ & & $\begin{array}{c}8.19 \\
(8.60)\end{array}$ & & $\begin{array}{l}-17.15 \\
(4.71)\end{array}$ & $* * *$ & $\begin{array}{l}-4.02 \\
(5.03)\end{array}$ & & $\begin{array}{l}-9.83 \\
(4.72)\end{array}$ & $* *$ \\
\hline occup: tech., engineer & $\begin{array}{c}0.24 \\
(16.51)\end{array}$ & & $\begin{array}{c}49.31 \\
(13.82)\end{array}$ & $* * *$ & $\begin{array}{c}15.53 \\
(13.00)\end{array}$ & & $\begin{array}{l}-6.59 \\
(7.81)\end{array}$ & & $\begin{array}{l}25.27 \\
(8.03)\end{array}$ & $* * *$ & $\begin{array}{l}18.23 \\
(7.18)\end{array}$ & $* *$ \\
\hline occup: simple services & $\begin{array}{c}54.22 \\
(12.28)\end{array}$ & $* * *$ & $\begin{array}{c}33.53 \\
(10.74)\end{array}$ & $* * *$ & $\begin{array}{c}0.95 \\
(10.21)\end{array}$ & & $\begin{array}{l}18.12 \\
(5.69)\end{array}$ & $* * *$ & $\begin{array}{c}4.53 \\
(6.06)\end{array}$ & & $\begin{array}{l}-14.51 \\
(5.55)\end{array}$ & \\
\hline occup: qualif. services & $\begin{array}{c}81.22 \\
(17.60)\end{array}$ & $* * *$ & $\begin{array}{c}46.05 \\
(14.67)\end{array}$ & $* * *$ & $\begin{array}{c}22.43 \\
(13.81)\end{array}$ & & $\begin{array}{c}4.67 \\
(9.43)\end{array}$ & & $\begin{array}{l}-9.00 \\
(9.72)\end{array}$ & & $\begin{array}{l}-7.63 \\
(8.58)\end{array}$ & \\
\hline occup: semi profession & $\begin{array}{l}100.00 \\
(16.99)\end{array}$ & $* * *$ & $\begin{array}{c}58.66 \\
(14.16)\end{array}$ & $* * *$ & $\begin{array}{c}41.57 \\
(13.67)\end{array}$ & $* * *$ & $\begin{array}{l}24.56 \\
(9.35)\end{array}$ & $* * *$ & $\begin{array}{l}26.44 \\
(9.41)\end{array}$ & $* * *$ & $\begin{array}{l}28.95 \\
(8.23)\end{array}$ & \\
\hline occup: profession & $\begin{array}{c}48.55 \\
(33.70)\end{array}$ & & $\begin{array}{l}104.30 \\
(28.08)\end{array}$ & $* * *$ & $\begin{array}{c}31.62 \\
(25.35)\end{array}$ & & $\begin{array}{l}176.90 \\
(18.72)\end{array}$ & $* * *$ & $\begin{array}{l}234.50 \\
(17.87)\end{array}$ & $* * *$ & $\begin{array}{l}265.90 \\
(14.73)\end{array}$ & $* * *$ \\
\hline occup: simp. sales & $\begin{array}{c}65.36 \\
(16.32)\end{array}$ & $* * *$ & $\begin{array}{c}51.45 \\
(13.61)\end{array}$ & $* * *$ & $\begin{array}{c}35.05 \\
(13.34)\end{array}$ & $* * *$ & $\begin{array}{l}36.59 \\
(7.37)\end{array}$ & $* * *$ & $\begin{array}{l}45.47 \\
(7.88)\end{array}$ & $* * *$ & $\begin{array}{l}21.26 \\
(7.32)\end{array}$ & $* *$ \\
\hline
\end{tabular}




\begin{tabular}{|c|c|c|c|c|c|c|c|c|c|c|c|c|}
\hline occup: qual. sales adm. & $\begin{array}{l}107.20 \\
(12.98)\end{array}$ & $* * *$ & $\begin{array}{c}99.03 \\
(11.06)\end{array}$ & $* * *$ & $\begin{array}{c}72.26 \\
(10.47)\end{array}$ & $* * *$ & $\begin{array}{l}99.14 \\
(6.04)\end{array}$ & $* * *$ & $\begin{array}{c}132.10 \\
(6.31)\end{array}$ & $* * *$ & $\begin{array}{l}76.44 \\
(5.63)\end{array}$ & $* * *$ \\
\hline occup: manager & $\begin{array}{l}137.70 \\
(22.78)\end{array}$ & $* * *$ & $\begin{array}{l}125.10 \\
(19.72)\end{array}$ & $* * *$ & $\begin{array}{c}67.96 \\
(19.34)\end{array}$ & $* * *$ & $\begin{array}{l}157.80 \\
(15.09)\end{array}$ & $* * *$ & $\begin{array}{l}208.90 \\
(15.10)\end{array}$ & $* * *$ & $\begin{array}{l}137.90 \\
(12.60)\end{array}$ & $* * *$ \\
\hline occup: misc. & $\begin{array}{l}-35.28 \\
(36.72)\end{array}$ & & $\begin{array}{c}44.44 \\
(40.18)\end{array}$ & & $\begin{array}{l}-13.15 \\
(34.70)\end{array}$ & & $\begin{array}{c}20.02 \\
(80.70)\end{array}$ & & $\begin{array}{l}117.70 \\
(42.20)\end{array}$ & $* * *$ & $\begin{array}{c}26.05 \\
(24.12)\end{array}$ & \\
\hline occupational change & $\begin{array}{c}151.50 \\
(8.52)\end{array}$ & $* * *$ & $\begin{array}{c}153.90 \\
(8.24)\end{array}$ & $* * *$ & $\begin{array}{c}169.60 \\
(8.67)\end{array}$ & $* * *$ & $\begin{array}{c}169.30 \\
(5.13)\end{array}$ & $* * *$ & $\begin{array}{c}182.30 \\
(5.22)\end{array}$ & $* * *$ & $\begin{array}{c}170.40 \\
(5.10)\end{array}$ & $* * *$ \\
\hline sector change & $\begin{array}{c}180.00 \\
(8.92)\end{array}$ & $* * *$ & $\begin{array}{c}175.70 \\
(8.53)\end{array}$ & $* * *$ & $\begin{array}{l}177.10 \\
(9.25)\end{array}$ & $* * *$ & $\begin{array}{c}155.60 \\
(5.41)\end{array}$ & $* * *$ & $\begin{array}{c}168.40 \\
(5.59)\end{array}$ & $* * *$ & $\begin{array}{l}211.00 \\
(5.27)\end{array}$ & $* * *$ \\
\hline Berlin & $\begin{array}{c}69.57 \\
(12.16)\end{array}$ & $* * *$ & $\begin{array}{c}77.89 \\
(10.06)\end{array}$ & $* * *$ & $\begin{array}{l}44.67 \\
(9.53)\end{array}$ & $* * *$ & - & & - & & - & \\
\hline Brandenburg & $\begin{array}{c}20.05 \\
(11.46)\end{array}$ & * & $\begin{array}{l}-1.35 \\
(9.55)\end{array}$ & & $\begin{array}{l}-7.65 \\
(9.21)\end{array}$ & & - & & - & & - & \\
\hline Mecklenburg-West P. & $\begin{array}{c}-5.25 \\
(12.64)\end{array}$ & & $\begin{array}{l}-32.83 \\
(10.67)\end{array}$ & $* * *$ & $\begin{array}{l}-17.39 \\
(10.27)\end{array}$ & * & - & & - & & - & \\
\hline Saxony & $\begin{array}{c}11.17 \\
(10.08)\end{array}$ & & $\begin{array}{c}8.09 \\
(8.43)\end{array}$ & & $\begin{array}{l}-2.35 \\
(8.07)\end{array}$ & & - & & - & & - & \\
\hline Saxony-Anhalt & $\begin{array}{l}-19.53 \\
(11.18)\end{array}$ & & $\begin{array}{l}-8.19 \\
(9.38)\end{array}$ & & $\begin{array}{l}-8.20 \\
(9.12)\end{array}$ & & - & & - & & - & \\
\hline Hamburg & - & & - & & - & & $\begin{array}{c}11.79 \\
(11.55)\end{array}$ & & $\begin{array}{c}34.11 \\
(12.29)\end{array}$ & $* * *$ & $\begin{array}{c}39.41 \\
(11.23)\end{array}$ & $* * *$ \\
\hline Lower Saxony & - & & - & & - & & $\begin{array}{l}-8.02 \\
(8.99)\end{array}$ & & $\begin{array}{l}-3.71 \\
(9.40)\end{array}$ & & $\begin{array}{r}-17.91 \\
(8.57)\end{array}$ & ** \\
\hline Bremen & - & & - & & - & & $\begin{array}{c}2.47 \\
(15.13)\end{array}$ & & $\begin{array}{c}9.73 \\
(16.13)\end{array}$ & & $\begin{array}{l}-35.86 \\
(14.81)\end{array}$ & $* *$ \\
\hline NRW & - & & - & & - & & $\begin{array}{l}11.89 \\
(8.31)\end{array}$ & & $\begin{array}{l}21.83 \\
(8.71)\end{array}$ & $* *$ & $\begin{array}{c}3.92 \\
(7.97)\end{array}$ & \\
\hline Hesse & - & & - & & - & & $\begin{array}{c}8.12 \\
(9.19)\end{array}$ & & $\begin{array}{l}13.98 \\
(9.68)\end{array}$ & & $\begin{array}{l}10.71 \\
(8.84)\end{array}$ & \\
\hline Rhineland-Pal. & - & & - & & - & & $\begin{array}{c}4.55 \\
(10.05)\end{array}$ & & $\begin{array}{c}2.51 \\
(10.52)\end{array}$ & & $\begin{array}{l}-6.90 \\
(9.60)\end{array}$ & \\
\hline Baden-Wü. & - & & - & & - & & $\begin{array}{l}10.97 \\
(8.64)\end{array}$ & & $\begin{array}{l}21.61 \\
(9.07)\end{array}$ & $* *$ & $\begin{array}{c}4.95 \\
(8.27)\end{array}$ & \\
\hline Bavaria & - & & - & & - & & $\begin{array}{l}-4.97 \\
(8.52)\end{array}$ & & $\begin{array}{c}5.57 \\
(8.93)\end{array}$ & & $\begin{array}{l}-6.51 \\
(8.16)\end{array}$ & \\
\hline Saarland & - & & - & & - & & $\begin{array}{c}19.06 \\
(13.43)\end{array}$ & & $\begin{array}{c}1.85 \\
(14.05)\end{array}$ & & $\begin{array}{l}-10.75 \\
(12.85)\end{array}$ & \\
\hline constant & $\begin{array}{l}88.09 \\
(3.32)\end{array}$ & $* * *$ & $\begin{array}{c}200.10 \\
(8.24)\end{array}$ & $* * *$ & $\begin{array}{c}155.70 \\
(6.26)\end{array}$ & $* * *$ & $\begin{array}{l}172.30 \\
(12.44)\end{array}$ & $* * *$ & $\begin{array}{l}362.10 \\
(25.55)\end{array}$ & $* * *$ & $\begin{array}{l}216.10 \\
(16.24)\end{array}$ & $* * *$ \\
\hline $\mathbf{N}$ & 60,67 & & 51,89 & & 46,34 & & 189,5 & & 189,6 & & 187,6 & 681 \\
\hline R-sq & 0.09 & & 0.11 & & 0.11 & & 0.09 & & 0.09 & & 0.09 & \\
\hline
\end{tabular}

Notes: t-statistics in parentheses; *, **, and ${ }^{* * *}$ indicates statistical significance at the 5,1 , and .1 percent level.

Source: SIAB (1975-2008). 
Table EA.3 Decomposition Results - Robustness Test: Swapping $t=0$ and $t=1$

\begin{tabular}{lcc}
\hline & & \\
period 0 & $1993-1997$ & $1993-1997$ \\
period 1 & $2004-2008$ & $2004-2008$ \\
& East & West \\
\hline \hline
\end{tabular}

\begin{tabular}{lcc} 
A. Description & & \\
period 1 & $390.19 * * *$ & $265.70 * * *$ \\
& $(3.30)$ & $(1.58)$ \\
period 0 & $191.09 * * *$ & $224.39 * * *$ \\
& $(2.44)$ & $(1.38)$ \\
change & $-199.10 * * *$ & $-41.31 * * *$ \\
& $(4.10)$ & $(1.98)$ \\
\hline & & \\
B. Aggregate Decomposition & -0.17 \\
composition & $-66.75 * * *$ & $(2.14)$ \\
& $(3.73)$ & $-39.20 * * *$ \\
structure & $-135.33 * * *$ & $(2.26)$ \\
& $(3.66)$ & \\
\hline & & $-9.10 * * *$ \\
C. Detailed Decomposition & of Composition Effect \\
Z - individual & $-10.52 * * *$ & $(1.01)$ \\
& $(1.49)$ & $3.81 * * *$ \\
$\mathrm{~J}$ - job stability & $-28.40 * * *$ & $(1.07)$ \\
& $(2.13)$ & $5.31 * * *$ \\
E - employment & $-29.30 * * *$ & $(0.94)$ \\
& $(2.82)$ & $-0.19 * *$ \\
R - regional & $1.47 * * *$ & $(0.08)$ \\
& $(0.40)$ & -2.19 \\
approximation error & 4.06 & $(2.11)$ \\
reweighting error & $(4.87)$ & 0.24 \\
& -1.09 & $(0.85)$ \\
& $(1.65)$ & \\
& & \\
& &
\end{tabular}

Notes: See Table 1.

Source: SIAB (1975-2008). 
Table EA.4 P-Values of Tests of Significant Changes in RIF Regression Coefficients over Time

\begin{tabular}{|c|c|c|c|c|c|c|}
\hline & \multicolumn{3}{|c|}{ East } & \multicolumn{3}{|c|}{ West } \\
\hline & $\begin{array}{c}1993 \text { vs. } \\
2004\end{array}$ & $\begin{array}{c}1993 \text { vs. } \\
1998\end{array}$ & $\begin{array}{c}1998 \text { vs. } \\
2004\end{array}$ & $\begin{array}{c}1993 \text { vs. } \\
2004\end{array}$ & $\begin{array}{c}1993 \text { vs. } \\
1998\end{array}$ & $\begin{array}{c}1998 \text { vs } \\
2004\end{array}$ \\
\hline Z - individual & 0.00 & 0.00 & 0.00 & 0.00 & 0.00 & 0.00 \\
\hline J - job stability & 0.00 & 0.00 & 0.00 & 0.00 & 0.00 & 0.00 \\
\hline E - employment & 0.00 & 0.00 & 0.00 & 0.00 & 0.00 & 0.00 \\
\hline $\mathrm{R}$ - regional & 0.09 & 0.09 & 0.04 & 0.05 & 0.65 & 0.28 \\
\hline \multicolumn{7}{|l|}{ Z - individual } \\
\hline age & 0.02 & 0.00 & 0.27 & 0.03 & 0.00 & 0.00 \\
\hline start position & 0.00 & 0.00 & 0.01 & 0.00 & 0.00 & 0.00 \\
\hline education & 0.01 & 0.16 & 0.33 & 0.03 & 0.00 & 0.00 \\
\hline citizenship & 0.00 & 0.04 & 0.06 & 0.00 & 0.05 & 0.00 \\
\hline sex & 0.00 & 0.04 & 0.02 & 0.07 & 0.00 & 0.00 \\
\hline migrates west & 0.69 & 0.16 & 0.23 & - & - & - \\
\hline \multicolumn{7}{|l|}{ J - job stability } \\
\hline firm change & 0.52 & 0.01 & 0.03 & 0.80 & 0.11 & 0.15 \\
\hline unemployment & 0.00 & 0.00 & 0.07 & 0.00 & 0.00 & 0.00 \\
\hline tenure & 0.02 & 0.04 & 0.00 & 0.08 & 0.00 & 0.00 \\
\hline \multicolumn{7}{|l|}{ E - employment } \\
\hline firm size & 0.00 & 0.00 & 0.00 & 0.00 & 0.00 & 0.00 \\
\hline industry & 0.00 & 0.00 & 0.00 & 0.00 & 0.00 & 0.00 \\
\hline shrinking workforce & 0.41 & 0.13 & 0.41 & 0.01 & 0.32 & 0.10 \\
\hline occupation group & 0.00 & 0.00 & 0.25 & 0.00 & 0.00 & 0.00 \\
\hline occupation change & 0.17 & 0.91 & 0.17 & 0.90 & 0.08 & 0.08 \\
\hline industry change & 0.86 & 0.92 & 0.99 & 0.00 & 0.10 & 0.00 \\
\hline
\end{tabular}

Notes: The table presents p-values of F-tests of the hypothesis that groups of coefficients remained constant over time. They are based on regressions as presented in Table EA.2. These specifications were extended by interaction terms of time indicators with the explanatory variables. The joint statistical significance of these interaction term coefficients is tested. Columns 1 and 4 show results for coefficient changes over the entire period, i.e. between 1993 and 2004, the other columns test for coefficient changes in the subperiods.

Source: SIAB (1975-2008). 
Table EA.5 Decomposition Results - Robustness Test: Using National Ranks

\begin{tabular}{llll}
\hline & & & \\
period 1 & $1993-1997$ & $1998-2002$ & $1993-1997$ \\
period 0 & $1998-2002$ & $2004-2008$ & $2004-2008$ \\
& & East Germany & \\
& & \\
\hline \hline
\end{tabular}

\begin{tabular}{|c|c|c|c|}
\hline \\
\hline $\begin{array}{l}\text { A. Description } \\
\text { period } 1\end{array}$ & $\begin{array}{l}305.60 \text { *** } \\
(2.58)\end{array}$ & $\begin{array}{l}207.14 * * * \\
(2.41)\end{array}$ & $\begin{array}{l}305.60 \text { *** } \\
(2.50)\end{array}$ \\
\hline period 0 & $\begin{array}{l}207.14 * * * \\
(2.56)\end{array}$ & $\begin{array}{l}167.69 * * * \\
(2.36)\end{array}$ & $\begin{array}{l}167.69 \text { *** } \\
(2.28)\end{array}$ \\
\hline change & $\begin{array}{l}-98.46 * * * \\
(3.75)\end{array}$ & $\begin{array}{l}-39.45 * * * \\
(3.63)\end{array}$ & $\begin{array}{c}-137.91 * * * \\
(3.41)\end{array}$ \\
\hline \multicolumn{4}{|c|}{ B. Aggregate Decomposition } \\
\hline composition & $\begin{array}{l}-25.52 * * * \\
(2.24)\end{array}$ & $\begin{array}{l}-27.54 * * * \\
(3.01)\end{array}$ & $\begin{array}{l}-61.26 * * * \\
(4.35)\end{array}$ \\
\hline structure & $\begin{array}{l}-72.11 * * * \\
(4.08)\end{array}$ & $\begin{array}{l}-15.44 * * * \\
(3.97)\end{array}$ & $\begin{array}{l}-89.00 * * * \\
(6.56)\end{array}$ \\
\hline \multicolumn{4}{|c|}{ C. Detailed Decomposition of Composition Effect } \\
\hline Z - individual & $\begin{array}{l}-4.02 * * * \\
(1.45)\end{array}$ & $\begin{array}{l}-10.19 * * * \\
(2.14)\end{array}$ & $\begin{array}{l}-13.14^{* * *} \\
(3.35)\end{array}$ \\
\hline J - job stability & $\begin{array}{l}-16.90 * * * \\
(1.33)\end{array}$ & $\begin{array}{l}-10.95 * * * \\
(1.21)\end{array}$ & $\begin{array}{l}-28.58 * * * \\
(2.28)\end{array}$ \\
\hline E - employment & $\begin{array}{l}-4.00 * * * \\
(1.45)\end{array}$ & $\begin{array}{l}-6.24 * * * \\
(1.67)\end{array}$ & $\begin{array}{l}-18.52 \text { *** } \\
(2.39)\end{array}$ \\
\hline $\mathrm{R}$ - regional & $\begin{array}{l}-0.60 * \\
(0.33)\end{array}$ & $\begin{array}{l}-0.16 \\
(0.19)\end{array}$ & $\begin{array}{l}-1.01^{* * *} \\
(0.33)\end{array}$ \\
\hline approximation error & $\begin{array}{l}-2.27 \\
(4.85)\end{array}$ & $\begin{array}{l}-1.87 \\
(4.58)\end{array}$ & $\begin{array}{l}-2.47 \\
(8.40)\end{array}$ \\
\hline reweighting error & $\begin{array}{r}1.44 \\
(1.12)\end{array}$ & $\begin{array}{l}5.39 \text { *** } \\
(1.60)\end{array}$ & $\begin{array}{l}14.81 \text { *** } \\
(3.07)\end{array}$ \\
\hline
\end{tabular}

Notes: See Table 1.

Source: SIAB (1975-2008). 